\title{
Ewolucjonizm darwinowski w świetle genomiki
}

\section{Wprowadzenie}

Książka Karola Darwina O powstawaniu gatunków, która ukazała się w 1859 roku w Londynie, ${ }^{1}$ zawierała pierwsze wiarygodne, szczegółowe ujęcie ewolucji biologicznej, nie licząc niezależnie opracowanych, krótkich szkiców Darwina i Alfreda Russella Wallace'a opublikowanych równocześnie rok wcześniej. ${ }^{2}$ Oczywiście Darwin nie odkrył procesu ewolucji i nawet nie dostarczył

Eugene V. Koonin, Рн.D. - National Center for Biotechnology Information, e-mail: koonin @ ncbi.nlm.nih.gov.

(C) Copyright by Eugene V. Koonin, Nucleic Acids Research, Dariusz Sagan \& Filozoficzne Aspekty Genezy.

*Eugene V. Koonin, „Darwinian Evolution in the Light of Genomics”, Nucleic Acids Research 2009, vol. 37, no. 4, s. 1011-1034, https://www.ncbi.nlm.nih.gov/pmc/articles/PMC26518 12/pdf/gkp089.pdf (11.05.2018). Za zgodą Autora z języka angielskiego przełożył: Dariusz SAGAN.

${ }^{1}$ Por. przekład polski: Karol DARWIN, O powstawaniu gatunków drogą doboru naturalnego, czyli o utrzymaniu się doskonalszych ras $\mathbf{w}$ walce $\mathrm{o}$ byt, tekst polski na podstawie przekładu Szymona Dicksteina i Józefa Nusbauma opracowały Joanna Popiołek i Małgorzata Yamazaki, Wydawnictwa Uniwersytetu Warszawskiego, Warszawa 2009.

${ }^{2}$ Por. Charles Darwin, „On the Tendency of Species to Form Varieties; And on the Perpetuation of Varieties and Species by Natural Means of Selection. I. Extract from an Unpublished Work on Species, II. Abstract of a Letter from C. Darwin, esq., to Prof. Asa Gray”, Journal of the Proceedings of the Linnean Society of London 1858, vol. 3, s. 45-53; Alfred R. Wallace, „On the Tendency of Species to Form Varieties; And on the Perpetuation of Varieties and Species by Nat ural Means of Selection. III. On the Tendency of Varieties to Depart Indefinitely from the Original Type", Journal of the Proceedings of the Linnean Society of London 1858, vol. 3, s. 53-62 (przekład polski: Alfred R. Wallace, „O dążności odmian do nieograniczonego odbiegania od 
pierwszego spójnego opisu ewolucji — zaszczytu tego doświadczył zapewne Jean-Baptiste Lamarck, którego opus magnum Filozofia zoologii ${ }^{3}$ zostało opublikowane, co ciekawe, w roku narodzin Darwina. Obraz ewolucji przedstawiony przez Lamarcka wskazywał jednak na wewnętrzne dążenie ewoluujących organizmów do doskonałości, a jest to idea niemożliwa do zaakceptowania przez racjonalnie zorientowany umysł. Poza tym Lamarck nie mówił o uniwersalnym charakterze ewolucji: postulował wielokrotne akty stworzenia, najprawdopodobniej po jednym dla każdego gatunku. Darwin jako pierwszy zaprezentował racjonalny, mechanistyczny i - co należy przyznać - wspaniały obraz pochodzenia całej różnorodności form życia „z tak prostego początku”, ${ }^{4}$ prawdopodobnie od jednego wspólnego przodka. Darwinowska wizja ewolucji życia była na tyle kompletna i potężna, aby przekonać lub przynajmniej głęboko wpłynąć na umysły większości biologów (oraz naukowców, a także wykształconych osób w ogóle). Wszystkie badania w ciągu ostatnich 150 lat prowadzono zatem w ramach ustalonych przez $\mathbf{O}$ powstawaniu gatunków (nawet jeśli ich wyniki przeczyły ideom Darwina).

Wizja Darwina pozbawiona była zasadniczego fundamentu w postaci genetyki, ponieważ w jego czasach nie znano mechanizmów dziedziczności (praca Mendla nie została dostrzeżona, a własne idee Darwina w tym obszarze nie były zbyt owocne). Genetyczną podstawę ewolucji ustanowiono dopiero po ponownym odkryciu praw Mendla i wraz z rozwojem genetyki populacyjnej w pierwszych trzydziestu latach dwudziestego wieku, głównie dzięki pionierskiej pracy Ronalda Fishera, Sewalla Wrighta i Johna Haldane'a. ${ }^{5}$ Nowe, udoskonalone ujęcie ewolucji, opierające się na teoretycznych i eksperymentalnych badaniach w ramach genetyki, zostało skonsolidowane w formie Nowoczesnej Syntezy biologii ewolucyjnej, łączonej zwykle z nazwiskami Theodosiusa Dobzhan-

typu pierwotnego", przeł. Kazimierz Szarski, w: Kazimierz Petrusewicz (red.), Teoria ewolucji w wypisach, Wiedza Powszechna, Warszawa 1959, s. 81-91).

${ }^{3}$ Por. przekład polski: Jean-Baptiste DE LAMARck, Filozofia zoologii, przeł. Krystyna Zaćwilichowska, Polskie Wydawnictwo Naukowe, Warszawa 1960.

${ }^{4}$ DARWIN, O powstawaniu gatunków..., s. 450.

${ }^{5}$ Por. Ronald A. Fisher, The Genetical Theory of Natural Selection, Clarendon Press, Oxford 1930; Sewall Wright, Evolution: Selected Papers, University of Chicago Press, Chicago 1986; John B.S. Haldane, The Causes of Evolution, Longmans, Green \& Co., London 1932. 
sky'ego, Juliusa Huxleya, Ernsta Mayra i George'a Gaylorda Simpsona. ${ }^{6}$ Wygląda na to, że Nowoczesna Synteza (neodarwinizm) uzyskała dojrzałą postać podczas obchodów setnej rocznicy wydania $\mathbf{O}$ powstawaniu gatunków, które odbyły się w Chicago w 1959 roku. ${ }^{7}$

Obecnie, 50 lat po skonsolidowaniu Nowoczesnej Syntezy, biologia ewolucyjna niewątpliwie stoi $\mathrm{w}$ obliczu nowego wyzwania $\mathrm{i}$ - jednocześnie - perspektywy nowego przełomu pojęciowego. ${ }^{8}$ Jeżeli Nowoczesną Syntezę można zwięźle opisać jako Darwinizm w Świetle Genetyki (często określany mianem neodarwinizmu), to nowym etapem jest Biologia Ewolucyjna w Świetle Genomiki. W niniejszym artykule podejmuję próbę przedstawienia zmian, jakie do podstawowych zasad biologii ewolucyjnej wnoszą genomika porównawcza i funkcjonalna. Argumentuję również, że pod wieloma względami etap genomiczny może okazać się znacznie radykalniejszym odstępstwem od neodarwinizmu niż neodarwinizm stanowił odstępstwo od klasycznego darwinizmu. W tym celu najpierw należy, rzecz jasna, podsumować główne koncepcje ewolucji zaproponowane przez Darwina i udoskonalone przez architektów Nowoczesnej Syntezy. W pozostałej części artykułu powrócę do każdego z poniższych punktów.

i. Niekierowana, losowa zmienność stanowi główny proces zapewniający materiał dla ewolucji. Darwin jako pierwszy uznał przypadek za ważny czynnik w dziejach życia i należy uznać, że była to jedna z jego najważniejszych idei.

ii. Ewolucja zachodzi drogą utrwalania rzadkich korzystnych zmian i eliminacji zmian szkodliwych: jest to proces doboru naturalnego, który

\footnotetext{
${ }^{6}$ Por. Theodosius Dobzhansky, Genetics and the Origin of Species, Columbia University Press, New York 1937; Julian S. HuxLey, Evolution: The Modern Synthesis, Allen and Unwin, London 1942; Ernst MAYR, Systematics and the Origin of Species, Columbia University Press, New York 1944; George Gaylord Simpson, Tempo and Mode in Evolution, Columbia University Press, New York 1944.

${ }^{7}$ Por. Sol TAx and Charles Callender (eds.), Evolution After Darwin: The University of Chicago Centennial, University of Chicago Press, Chicago 1960; Stephen Jay Gould, The Structure of Evolutionary Theory, Harvard University Press, Cambridge, Massachusetts 2002; Janet BRowne, „Birthdays to Remember”, Nature 2008, vol. 456, s. 324-325.

${ }^{8}$ Por. Michael R. Rose and Todd H. OAkley, „The New Biology: Beyond the Modern Synthesis", Biology Direct 2007, vol. 2, no. 30.
} 
obok losowej zmienności stanowi, zgodnie z ustaleniami Darwina i przedstawicieli Nowoczesnej Syntezy, główną siłę napędową ewolucji. Dobór naturalny, wyraźnie przypominający i inspirowany „niewidzialną ręką" (rynku), która według Adama Smitha rządzi ekonomią, to pierwszy mechanizm ewolucji, który był prosty, wiarygodny i nie wymagał żadnych tajemniczych wewnętrznych skłonności. Była to druga kluczowa idea Darwina. Ojcowie genetyki populacyjnej, zwłaszcza Sewall Wright, podkreślali, że przypadek może odgrywać znaczącą rolę w utrwalaniu zmian ewolucyjnych nie tylko przy ich powstawaniu, a to za sprawą zjawiska dryfu genetycznego skutkującego losowym utrwalaniem neutralnych lub nawet szkodliwych zmian. Teoria genetyki populacyjnej wskazuje, że dryf jest szczególnie ważny w małych populacjach przechodzących przez wąskie gardła. ${ }^{9}$ Jednak Nowoczesna Synteza, w swej ,usztywnionej” formie, ${ }^{10}$ całkowicie odrzuciła dryf jako ważną siłę ewolucyjną i pozostała wierna adaptacjonistycznemu modelowi ewolucji. ${ }^{11}$ Model ten nieuchronnie wiąże się z pojęciem ,postępu”, to znaczy z ideą stopniowego udoskonalania „narządów” w procesie ewolucji - Darwin uznał, że wyraża ona ogólny trend. Zaakceptował ją, pomimo że doskonale wiedział, iż organizmy nie są doskonale przystosowane, o czym dobitnie świadczą narządy szczątkowe, i mimo że czuł odrazę do jakichkolwiek sił przypominających wewnętrzne dążenie do doskonałości, o którym mówił na przykład Lamarck.

iii. Korzystne zmiany utrwalane przez dobór naturalny są „nieskończenie” małe, a więc ewolucja zachodzi drogą stopniowej kumulacji tych maleńkich przekształceń. Darwin chciał, aby ścisły gradualizm stanowił istotny element jego teorii: „Dobór naturalny może działać jedynie drogą zachowywania i nagromadzania nieskończenie drobnych dziedzicznych zmian, korzystnych dla zachowanego organizmu. [...] Gdyby można było wykazać, że istnieje jakikolwiek narząd złożony, który nie

\footnotetext{
${ }^{9}$ Por. Wright, Evolution...; Michael Lynch, The Origins of Genome Architecture, Sinauer Associates, Sunderland, Massachusetts 2007.

${ }^{10}$ Por. Gould, The Structure of Evolutionary Theory....

${ }^{11}$ Por. Motoo Kimura, „Recent Development of the Neutral Theory Viewed from the Wrightian Tradition of Theoretical Population Genetics", Proceedings of the National Academy of Sciences USA 1991, vol. 88, s. 5969-5973.
} 
mógłby powstać drogą licznych następujących po sobie drobnych przekształceń - moja teoria musiałaby absolutnie upaść". ${ }^{12}$ Nawet niektórzy współcześni Darwinowi uważali, że było to niepotrzebne ograniczenie tej teorii. Szczególnie dobrze znane są wczesne zarzuty Thomasa Huxleya. Już przed publikacją O powstawaniu gatunków Huxley napisał do Darwina: „Sprawiłeś sobie niepotrzebny kłopot, bezkompromisowo przyjmując dyktat Natura non facit saltum". ${ }^{13}$

iv. Aspektem klasycznej biologii ewolucyjnej, który wiąże się, choć nie jest identyczny, z przyjętym odgórnie gradualizmem, jest uniformitarianizm (zapożyczony przez Darwina z geologii Lyella), czyli pogląd, zgodnie z którym procesy ewolucyjne były, w zasadzie, takie same przez całe dzieje życia.

v. Ewolucję życia można przedstawić jako ,wielkie drzewo”, co sugeruje jedyny, słynny diagram w $\mathbf{O}$ powstawaniu gatunków. ${ }^{14}$

vi. A oto następstwo koncepcji jednego drzewa życia, które zasługuje na status odrębnej zasady: cała współczesna różnorodność form życia wyewoluowała od jednego wspólnego przodka (lub kilku tylko form ancestralnych, jak ostrożnie sugerował Darwin ${ }^{15}$ ), nazwanego znacznie później Ostatnim Uniwersalnym Wspólnym (Komórkowym) Przodkiem (LUCA — Last Universal Common Ancestor). ${ }^{16}$

\section{Między Nowoczesną Syntezą a genomiką ewolucyjną}

Rzecz jasna, biologowie ewolucyjni nie pozostawali bezczynni przez 40 lat oddzielających Nowoczesną Syntezę od nadchodzącej ery genomiki ewolucyj-

\footnotetext{
${ }^{12}$ DARWIN, O powstawaniu gatunków..., s. 90, 178.

${ }^{13}$ Por. Sherrie L. Lyons, Thomas Henry Huxley: The Evolution of a Scientist, Prometheus, Amherst - New York 2000.

${ }^{14}$ Por. Darwin, O powstawaniu gatunków..., s. 108.

${ }^{15}$ Por. Darwin, O powstawaniu gatunków..., s. 450.

${ }^{16}$ Por. Antonio Lazcano and Patrick Forterre, ,The Molecular Search for the Last Common Ancestor", Journal of Molecular Evolution 1999, vol. 49, s. 411-412.
} 
nej. Poniżej krótko podsumuję najważniejsze nowe ustalenia (niewątpliwie ten krótki opis jest niekompletny i można go uznać za nieco subiektywny).

\section{Ewolucja molekularna a filogeneza}

Tradycyjna filogeneza, która potwierdzała Darwinowską koncepcję drzewa życia, opierała się na porównaniach charakterystycznych cech morfologii organizmów, takich jak struktura szkieletu zwierząt i architektura kwiatów roślin. ${ }^{17}$ Idea, że faktyczny molekularny substrat ewolucji, przechodzący zmiany, na które oddziałuje dobór naturalny (czyli po prostu geny), może stanowić podstawę analizy porównawczej dokonywanej w celu opracowania rekonstrukcji filogenezy, nie przyszła biologom ewolucyjnym do głowy z tego prostego powodu, że (prawie) nic nie wiedziano wówczas o chemicznej naturze tego substratu, a także o sposobie, w jaki koduje on fenotyp organizmu. Co więcej, adaptacjonistyczny paradygmat biologii ewolucyjnej zdawał się implikować, że geny, bez względu na ich molekularną naturę, nie będą się dobrze utrwalać między odlegle spokrewnionymi organizmami, zważywszy na duże różnice między ich fenotypami, co podkreślał zwłaszcza Mayr, jeden z głównych architektów Nowoczesnej Syntezy. ${ }^{18}$

Idea, zgodnie z którą sekwencje zasad DNA można wykorzystać do rekonstrukcji ewolucji, po raz pierwszy została przedstawiona drukiem zapewne przez Francisa Cricka w tym samym doniosłym artykule, w którym przedstawił on hipotezę adaptorów. ${ }^{19}$ Do sformułowania rzeczywistych zasad i pierwszej implementacji ewolucyjnej analizy molekularnej doszło kilka lat później, co zawdzięczamy pracy Emile'a Zuckerkandla i Linusa Paulinga. Bezpośrednio sfalsyfikowali oni przypuszczenie Mayra, pokazując, że znane w tamtym czasie sekwencje aminokwasów różnych białek, takich jak cytochrom $c$ i globiny, uległy wy-

\footnotetext{
${ }^{17}$ Por. Douglas J. Futuyma, Ewolucja, przekł. pod red. Jacka Radwana, Wydawnictwa Uniwersytetu Warszawskiego, Warszawa 2008.

${ }^{18}$ Por. Ernst MAYr, „The Emergence of Evolutionary Novelties”, w: Sol TAX (ed.), The Evolution of Life: Evolution After Darwin, vol. 1, University of Chicago Press, Chicago 1959, s. 349-380.

${ }^{19}$ Por. Francis H. CRick, „On Protein Synthesis”, Symposia of the Society for Experimental Biology 1958, vol. 12, s. 138-163.
} 
sokiemu utrwaleniu pośród odlegle spokrewnionych zwierząt. ${ }^{20}$ Zuckerkandl i Pauling zaproponowali również koncepcję zegara molekularnego, mówiącą o względnie stałym tempie ewolucji sekwencji charakterystycznym, zgodnie z ich przewidywaniami, dla każdego białka, którego funkcja nie ulega zmianie. W kolejnych kilku latach, głównie dzięki pracy Margaret Dayhoff i współpracowników, wykazano, że utrwalenie sekwencji białek występuje także u najbardziej różniących się od siebie form życia, od bakterii po ssaki. ${ }^{21}$

Punktem kulminacyjnym wczesnej fazy badań ewolucji molekularnej była praca Carla Woese i współpracowników, w ramach której wykazano utrwalenie się sekwencji pewnych cząsteczek, zwłaszcza rybosomowego RNA, u wszystkich komórkowych form życia, jak również ich przydatność dla analizy filogenetycznej. ${ }^{22}$ Szczytowym osiągnięciem w tej linii badań było zupełnie nieoczekiwane odkrycie trzeciej domeny życia — archeonów — do której zaliczane są organizmy wrzucane wcześniej do jednego worka z bakteriami. Filogenetyczna analiza rRNA wykazała jednak zasadniczą odmienność archeonów od bakterii. ${ }^{23} \mathrm{~W}$ rezultacie tych badań coraz częściej zaczęto przyrównywać filogenetyczne drzewa rRNA, dotyczące trzech domen, ${ }^{24}$ do drzewa życia przewidywa-

\footnotetext{
${ }^{20}$ Por. Emile Zuckerkandl and Linus Pauling, ,Molecular Disease, Evolution and Genic Hetero-Geneity”, w: Michael Kasha and Bernard Pullman (eds.), Horizons in Biochemistry, Academic Press, New York 1962, s. 189-225; Emile Zuckerkandl and Linus Pauling, „Evolutionary Divergence and Convergence in Proteins", w: Vernon Bryson and Henry Vogel (eds.), Evolving Gene and Proteins, Academic Press, New York 1965, s. 97-166.

${ }^{21}$ Por. Margaret O. DAYHOFF, Winona C. BARKER, and Patrick J. McLaughlin, „Inferences from Protein and Nucleic Acid Sequences: Early Molecular Evolution, Divergence of Kingdoms and Rates of Change", Origins of Life 1974, vol. 5, s. 311-330; Richard V. EcK and Margaret O. DAYHOFF, „Evolution of the Structure of Ferredoxin Based on Living Relics of Primitive Amino Acid Sequences", Science 1966, vol. 152, s. 363-366; Margaret O. DAYHoff, Winona C. BARKer, and Lois T. Hunt, „Establishing Homologies in Protein Sequences”, Methods in Enzymology 1983, vol. 91, s. 524-545. 271.

${ }^{22}$ Por. Carl R. WoEse, „Bacterial Evolution”, Microbiological Reviews 1987, vol. 51, s. 221-

${ }^{23}$ Por. Carl R. WoEse and George E. Fox, „Phylogenetic Structure of the Prokaryotic Domain: The Primary Kingdoms", Proceedings of the National Academy of Sciences USA 1977, vol. 74, s. 5088-5090; Carl R. Woese, Linda J. Magrum, and George E. Fox, „Archaebacteria”, Journal of Molecular Evolution 1978, vol. 11, s. 245-251.

${ }^{24}$ Por. Carl R. Woese, Otto Kandler, and Mark L. Wheelis, „Towards a Natural System of Organisms: Proposal for the Domains Archaea, Bacteria, and Eucarya”, Proceedings of the National Academy of Sciences USA 1990, vol. 87, s. 4576-4579.
} 
nego przez Darwina i po raz pierwszy objaśnionego przez Ernsta Haeckela. ${ }^{25}$ Jednakże, jeszcze w erze przedgenomicznej, stało się jasne, że nie wszystkie drzewa genów kodujących białka mają taką samą topologię jak drzewo rRNA. Przyczyny tych rozbieżności pozostają niejasne, ale sądzi się, że mają one związek z horyzontalnym transferem genów (HGT - horizontal gene transfer). ${ }^{26}$

\section{Teoria neutralna i dobór oczyszczający}

Wydaje się, że najważniejszym przełomem pojęciowym w biologii ewolucyjnej po powstaniu Nowoczesnej Syntezy była neutralna teoria ewolucji molekularnej, zwykle łączona z nazwiskiem Motoo Kimury, ${ }^{27}$ chociaż podobną teorię jednocześnie i niezależnie rozwinęli Thomas Jukes i Jack King. ${ }^{28}$ Pierwotnie teoria neutralna powstała jako rozwinięcie idei Wrighta w zakresie genetyki populacyjnej na temat znaczenia dryfu genetycznego $\mathrm{w}$ ewolucji. Zgodnie z teorią neutralną znakomita większość mutacji utrwalanych w procesie ewolucji jest neutralna pod względem selekcyjnym, co znaczy, że za ich utrwalanie odpowiada losowy dryf. Następstwem tej teorii jest to, że sekwencje genów ewoluują, w przybliżeniu, na wzór działania zegara (co potwierdza oryginalną hipotezę zegara molekularnego autorstwa Zuckerkandla i Paulinga), natomiast sporadyczne korzystne mutacje, podlegające działaniu doboru naturalnego, są na tyle rzadkie, że w ramach ilościowego opisu procesu ewolucji można potraktować je jako zaniedbywalne. Oczywiście nie należy sądzić, że w świetle teorii neutralnej dobór nie jest istotnym czynnikiem w ewolucji. Teoria ta głosi w istocie, że dominującym rodzajem doboru nie jest darwinowski pozytywny dobór mutacji adaptacyj-

\footnotetext{
${ }^{25}$ Por. WoEse, „Bacterial Evolution...”; Norman R. PACE, „A Molecular View of Microbial Diversity and the Biosphere”, Science 1997, vol. 276, s. 734-740; Norman R. PACE, „Time for a Change", Nature 2006, vol. 441, s. 289.

${ }^{26}$ Por. Michael Syvanen, „Molecular Clocks and Evolutionary Relationships: Possible Distortions Due to Horizontal Gene Flow", Journal of Molecular Evolution 1987, vol. 26, s. 16-23.

${ }^{27}$ Por. Motoo Kimura, „Evolutionary Rate at the Molecular Level”, Nature 1968, vol. 217, s. 624-626; Motoo Kimura, The Neutral Theory of Molecular Evolution, Cambridge University Press, Cambridge 1983.

${ }^{28}$ Por. Jack L. KING and Thomas H. Jukes, „Non-Darwinian Evolution”, Science 1969, vol. 164, s. 788-798.
} 
nych, lecz dobór stabilizujący czy oczyszczający, który eliminuje szkodliwe mutacje, umożliwiając utrwalanie mutacji neutralnych w wyniku dryfu. ${ }^{29}$

Dzięki kolejnym badaniom udoskonalono tę teorię i nadano jej bardziej realistyczny charakter $\mathrm{w}$ tym względzie, że aby mutacja została utrwalona, nie musi ona być dosłownie neutralna, a jedynie musi mieć na tyle małą szkodliwość, by mogła uniknąc eliminacji przez dobór oczyszczający — tę wersję nazwano nowoczesną teorią ,prawie neutralną”. ${ }^{30}$ To, które mutacje ,postrzegane" są przez dobór oczyszczający jako szkodliwe, zależy zasadniczo od rzeczywistego rozmiaru populacji: $\mathrm{w}$ małych populacjach dryf może utrwalić nawet mutacje w dużym stopniu szkodliwe. ${ }^{31}$ Główny sprawdzian empiryczny teorii (prawie) neutralnej zapewniają pomiary stałości tempa ewolucji w rodzinach genów. Mimo iż wielokrotnie obserwowano, że zegar molekularny wykazuje znacznie większe rozproszenie od przewidywanego (over-dispersed), ${ }^{32}$ testy takie wyraźnie wskazują, że mutacje neutralne rzeczywiście stanowią znaczną część mutacji utrwalonych. ${ }^{33}$ Teoria (prawie) neutralna stanowi wielkie odstępstwo od selekcjonistycznego paradygmatu Nowoczesnej Syntezy. Otwarcie bowiem postuluje ona, że darwinowski (pozytywny) dobór nie ma wpływu na większość mutacji utrwalanych w procesie ewolucji (Darwin niejako zapowiedział paradygmat neutralistyczny, gdy zwrócił uwagę, że cechy neutralne pod względem selekcyjnym najlepiej nadają się do celów klasyfikacji, ${ }^{34}$ nie rozwinął jednak tej idei i nie stała się ona częścią Nowoczesnej Syntezy).

Co ważne, w późniejszych opracowaniach teorii neutralnej Kimura i inni zdali sobie sprawę z tego, że mutacje (prawie) neutralne w momencie utrwalenia nie były obojętne dla procesu ewolucji. Przeciwnie, takie mutacje tworzyły pulę

\footnotetext{
${ }^{29}$ Por. KimuRA, „Recent Development of the Neutral Theory...”.

${ }^{30}$ Por. Tomoko Ohta and John H. Gillespie, „Development of Neutral and Nearly Neutral Theories", Theoretical Population Biology 1996, vol. 49, s. 128-142.

${ }^{31}$ Por. LyNCH, The Origins of Genome Architecture....

${ }^{32}$ Por. Naoyuki Tаканата, „On the Overdispersed Molecular Clock”, Genetics 1987, vol. 116, s. 169-179; David J. CutLeR, „Understanding the Overdispersed Molecular Clock”, Genetics 2000, vol. 154, s. 1403-1417.

${ }^{33}$ Por. Kimura, The Neutral Theory of Molecular Evolution....

${ }^{34}$ Por. DARwIN, O powstawaniu gatunków..., s. 385-389.
} 
zmian, które mogły zostać wykorzystane przez dobór naturalny w innych warunkach, co mogło być potencjalnie ważne dla procesu makroewolucji. ${ }^{35}$

\section{Samolubne geny, śmieciowe DNA i elementy ruchome}

Chociaż rzadko stwierdzano to otwarcie, klasyczna genetyka z pewnością implikuje, że (prawie) wszystkie składniki genomu (mówiąc bardziej współczesnym, molekularnym językiem - wszystkie nukleotydy) pełnią określoną funkcję. Tę niejawną implikację podano jednak w wątpliwość w latach sześćdziesiątych i siedemdziesiątych na podstawie zwiększającej się ilości danych o braku bezpośredniej korespondencji między genomową a fenotypową złożonością organizmów. Wykazano, że organizmy o mniej więcej tej samej złożoności fenotypowej często mają genomy różniące się rozmiarem i złożonością o rzędy wielkości (tak zwany paradoks wartości $c$ ). ${ }^{36}$ Ten paradoks uzyskał pojęciowe rozwiązanie dzięki dwóm pokrewnym, fundamentalnym ideom, mianowicie samolubnych genów i śmieciowego DNA. Koncepcję samolubnych genów rozwinął pierwotnie Dawkins w klasycznej książce o takim właśnie tytule. ${ }^{37}$ Dawkins zdał sobie sprawę z tego - wyraźnie odchodząc od organizmocentrycznego paradygmatu Nowoczesnej Syntezy — że dobór naturalny może oddziaływać nie tylko na poziomie całego organizmu, ale i na poziomie pojedynczego genu. W myśl nieco prowokacyjnego sformułowania tego poglądu genom i organizm są po prostu nośnikami rozprzestrzeniania genów. Koncepcję tę rozwinęli później W. Ford Doolittle i Carmen Sapienza ${ }^{38}$ oraz Leslie Orgel i Francis Crick, ${ }^{39}$ sugerując, że duża część, jeśli nie większość, genomowego DNA (przynajmniej

\footnotetext{
${ }^{35}$ Por. Kimura, „Recent Development of the Neutral Theory...”; Andreas Wagner, „Robustness, Evolvability, and Neutrality", FEBS Letters 2005, vol. 579, s. 1772-1778.

${ }^{36}$ Por. Charlie A. Thomas, Jr., „The Genetic Organization of Chromosomes”, Annual Review of Genetics 1971, vol. 5, s. 237-256; Daniel L. HARTL, „Molecular Melodies in High and Low C”, Nature Reviews Genetics 2000, vol. 1, s. 145-149.

${ }^{37}$ Por. Richard Dawkins, Samolubny gen, przeł. Marek Skoneczny, Na Ścieżkach Nauki, Prószyński i S-ka, Warszawa 1996.

${ }^{38}$ Por. W. Ford Doolittle and Carmen SAPIEnza, ,Selfish Genes, the Phenotype Paradigm and Genome Evolution”, Nature 1980, vol. 284, s. 601-603.

${ }^{39}$ Por. Leslie Orgel and Francis H. Crick, „Selfish DNA: The Ultimate Parasite”, Nature 1980, vol. 284, s. 604-607.
} 
w przypadku organizmów złożonych) składa się z różnych rodzajów powtórzeń biorących się z replikacji samolubnych elementów (przez Orgela i Cricka nazwanych ostatecznymi pasożytami). Innymi słowy, w perspektywie organizmu dużą część jego genomowego DNA należy uznać za śmieciową. Ten pogląd na genom drastycznie różni się od obrazu sugerowanego przez paradygmat selekcjonistyczny, zgodnie z którym na większość nukleotydów w genomie, o ile nie na wszystkie, wpływa (oczyszczający lub pozytywny) dobór działający na poziomie organizmu.

Pojęciowo powiązanym, wielkim osiągnięciem było odkrycie - najpierw $\mathrm{u}$ roślin przez Barbarę McClintock w latach czterdziestych, ${ }^{40}$ a potem u zwierząt ${ }^{41}$ — „skaczących genów”, nazwanych później elementami ruchomymi. Są to elementy genetyczne mające skłonność do częstej zmiany swojej pozycji w genomie. Wykazanie wszechobecności elementów ruchomych podsunęło, jeszcze przed nastaniem współczesnej genomiki, obraz wysoce dynamicznych, nieustannie zmieniających się genomów. ${ }^{42}$

\section{Ewolucja drogą duplikacji genów i genomów}

Centralna zasada Darwina - gradualistyczny nacisk na nieskończenie małe zmiany jako jedyny materiał ewolucji — została zakwestionowana przez koncepcję ewolucji drogą duplikacji sformułowaną przez Susumu Ohno w klasycznej książce z 1970 roku. ${ }^{43}$ Ideę, że duplikacja części chromosomów może mieć wpływ na ewolucję, wyrażali już niektórzy ojcowie współczesnej genetyki,

\footnotetext{
${ }^{40}$ Por. Barbara McClintock, „The Origin and Behavior of Mutable Loci in Maize”, Proceedings of the National Academy of Sciences USA 1950, vol. 36, s. 344-355.

${ }^{41}$ Por. Georgii P. Georgiev, Y.V. Ilyin, A.P. Ryskov, Nickolai A. Tchurikov, Grigori N. YenIKolopov, Vladimir A. Gvozdev, and E.V. Ananiev, „Isolation of Eukaryotic DNA Fragments Containing Structural Genes and the Adjacent Sequences", Science 1977, vol. 195, s. 394-397.

${ }^{42}$ Por. Georgii P. Georgiev, „Mobile Genetic Elements in Animal Cells and Their Biological Significance", European Journal of Biochemistry 1984, vol. 145, s. 203-220; David J. FinNEGAN, „Transposable Elements in Eukaryotes”, International Review of Cytology 1985, vol. 93, s. 281326.

${ }^{43}$ Por. Susumu Oнno, Evolution by Gene Duplication, Springer-Verlag, Berlin - Heidelberg — New York 1970.
} 
w szczególności Ronald Fisher, ${ }^{44}$ jednak Ohno jako pierwszy wysunął hipotezę, że duplikacja genów ma kluczowe znaczenie dla ewolucji genomów i organizmów, i poparł to przypuszczenie teorią o charakterze jakościowym. Biorąc za punkt wyjścia dane wskazujące na duplikację całego genomu na wczesnym etapie ewolucji strunowców, Ohno zasugerował, że duplikacja genów może stanowić ważną, jeśli nie główną, drogę ewolucji nowych funkcji biologicznych. Po duplikacji jedna z kopii genu byłaby bowiem wolna od ograniczeń narzucanych przez dobór oczyszczający i mogłaby stać się podstawą do wykształcenia nowej funkcji (zjawisko to nazwano później neofunkcjonalizacją). Najwyraźniej powstanie nowego genu na skutek duplikacji, a tym bardziej duplikacji regionu genomu zawierającego wiele genów lub nawet całego genomu, ewidentnie nie zachodzi drogą „nieskończenie małych” zmian. A jeśli takie większe zmiany rzeczywiście odgrywają ważną rolę w ewolucji, to paradygmat gradualistyczny jest zagrożony.

\section{Naroża luków, egzaptacja, majsterkowanie i ułomność panglossowskiego paradygmatu ewolucji}

Odważną, gruntowną krytykę programu adaptacjonistycznego w biologii ewolucyjnej przeprowadzili Stephen Jay Gould i Richard Lewontin w słynnym artykule „Spandrels of San Marco" [Naroża łuków w San Marco]. ${ }^{45}$ Światopogląd adaptacjonistyczny sarkastycznie nazwali oni paradygmatem panglossowskim, czyniąc aluzję do słynnego bohatera Wolterowskiego Kandyda, który był przekonany, że ,wszystko służy dobru w tym najlepszym ze wszystkich światów" (nawet wielkie katastrofy). Gould i Lewontin podkreślali, że zamiast pośpiesznie wymyślać „takie sobie bajeczki” o wiarygodnych adaptacjach, biologowie ewolucyjni powinni szukać wyjaśnień obserwowanych cech organizacji biologicznej, przyjmując podejście pluralistyczne, w ramach którego pod uwagę bierze się nie tylko dobór, ale i ograniczenia wewnętrzne, losowy dryf oraz inne czynniki. Metafora naroża łuku wskazuje, że wiele ważnych funkcjonalnie ele-

\footnotetext{
${ }^{44}$ Por. Ronald A. Fisher, „The Possible Modification of the Response of the Wild Type to Recurrent Mutations", The American Naturalist 1928, vol. 62, s. 115-126.

${ }^{45}$ Por. Stephen Jay Gould and Richard C. Lewontin, „The Spandrels of San Marco and the Panglossian Paradigm: A Critique of the Adaptationist Programme", Proceedings of the Royal Society of London B: Biological Sciences 1979, vol. 205, s. 581-598.
} 
mentów organizacji biologicznej nie wyewoluowało jako mechanizmy pełniące dokładnie te funkcje, jakie pełnią dzisiaj, lecz jako produkty nieadaptacyjnych ograniczeń architektonicznych. Podobnie jest z narożami łuków, które z konieczności stanowią część łuków w katedrach i innych budynkach i które można wykorzystać do różnych celów, na przykład jako podłoże dla kluczowych elementów malowideł zdobiących katedrę. Procesowi wykorzystującemu naroża łuków do celów biologicznych nadano specjalną nazwę egzaptacji, a Gould uznał go za ważną drogę ewolucji. ${ }^{46}$

Jeszcze wcześniej François Jacob propagował pojęciowo podobną metaforę ewolucji jako majsterkowania. ${ }^{47}$ Zgodnie $\mathrm{z}$ argumentem Jacoba, opierającym się głównie na rezultatach analizy porównawczej mechanizmów rozwojowych, ewolucja nie działa jak inżynier lub projektant, lecz jak majsterkowicz, który rozwiązując trudne problemy - w wielkim stopniu zależny jest od przeszłych przygodnych zdarzeń i którego działania są w związku z tym nieprzewidywalne i niewytłumaczalne bez szczegółowej wiedzy o wcześniejszym przebiegu ewolucji.

\section{Ewolucja w świecie mikrobów i wirusów}

Być może tym, co w biologii wywarło najgłębszy wpływ na zmiany w pojmowaniu ewolucji, było rozszerzenie zakresu badań na świat bakterii (oraz archeonów) i wirusów. Darwinowskie ujęcie ewolucji i wszystkie ustalenia biologii ewolucyjnej w kolejnych kilku dekadach dotyczyły wyłącznie zwierząt i roślin, przy czym jednokomórkowe eukarionty (protisty) i bakterie (prokarionty) zostały nominalnie umieszczone przez Haeckela i jego następców w pobliżu korzenia drzewa życia. ${ }^{48}$ Pomimo że w latach pięćdziesiątych dwudziestego wieku genetyczna analiza bakteriofagów i bakterii była już zaawansowana, czyniąc oczywistym, że genomy tych form życia podlegają ewolucji, ${ }^{49}$ Nowoczesna

\footnotetext{
${ }^{46}$ Por. Stephen Jay Gould, „The Exaptive Excellence of Spandrels as a Term and Prototype”, Proceedings of the National Academy of Sciences USA 1997, vol. 94, s. 10750-10755.

${ }^{47}$ Por. François JАСОВ, „Evolution and Tinkering”, Science 1977, vol. 196, s. 1161-1166.

${ }^{48}$ Por. Ernst Haeckel, The Wonders of Life: A Popular Study of Biological Philosophy, Watts \& Co., London 1904.

${ }^{49}$ Por. John Cairns, Gunther S. Stent, and James D. Watson (eds.), Phage and the Origins of
} 
Synteza w ogóle nie dostrzegła tych ustaleń. To, że bakterie (a co dopiero wirusy) będą ewoluować podług tych samych zasad i dzięki tym samym mechanizmom, co zwierzęta i rośliny, wcale nie jest oczywiste, jeśli zważymy na ich uderzającą biologiczną odmienność od organizmów wielokomórkowych, ale zwłaszcza dlatego, że w ich wypadku nie zachodzi regularne rozmnażanie płciowe, jak również nie występuje izolacja reprodukcyjna, która u zwierząt i roślin jest kluczowa dla specjacji.

Ostatecznie prokarionty stały się „widoczne” dla biologów ewolucyjnych w 1977 roku za sprawą przełomowej pracy Woese i współpracowników, dotyczącej filogenezy rRNA, czego efektem było zidentyfikowanie archeonów i głównych grup bakterii. ${ }^{50}$ Niedługo potem, gdy dysponowano już wieloma kompletnymi sekwencjami genomów różnych małych wirusów, narodziły się dziedziny genomiki porównawczej i ewolucyjnej. Pomimo szybkiego tempa ewolucji sekwencji charakterystycznego dla wirusów, dzięki wczesnym badaniom w ramach genomiki porównawczej udało się wyznaczyć zespoły genów utrwalanych w dużych grupach wirusów. ${ }^{51}$ Co więcej, oczywista stała się następująca ogólna zasada: podczas gdy niektóre geny utrwalały się u zdumiewająco różnorodnych wirusów, architektury genomów, struktury wirionów i biologiczne cechy wirusów ujawniały znacznie większą plastyczność. Tym samym jednym z głównym czynników w procesie ewolucji stała się wymiana genów, nawet między bardzo niepodobnymi wirusami. ${ }^{52}$

Molecular Biology, CSHL Press, Cold Spring Harbor, New York 1966.

${ }^{50}$ Por. Woese, „Bacterial Evolution...”; Woese and Fox, „Phylogenetic Structure...”; Carl R. Woese, „There Must Be a Prokaryote Somewhere: Microbiology's Search for Itself”, Microbiological Reviews 1994, vol. 58, s. 1-9.

${ }^{51}$ Por. Patrick Argos, Gregory Kamer, Martin J. Nickuin, and Eckard Wimmer, „Similarity in Gene Organization and Homology Between Proteins of Animal Picornaviruses and a Plant Comovirus Suggest Common Ancestry of These Virus Families", Nucleic Acids Research 1984, vol. 12, s. 7251-7267; Gregory Kamer and Patrick Argos, „Primary Structural Comparison of RNA-Dependent Polymerases from Plant, Animal and Bacterial Viruses”, Nucleic Acids Research 1984, vol. 12, s. 7269-7282; Rob Goldbach, „Genome Similarities Between Plant and Animal RNA Viruses”, Microbiological Sciences 1987, vol. 4, s. 197-202; Eugene V. Koonin and Valerian V. DolJA, „Evolution and Taxonomy of Positive-Strand RNA Viruses: Implications of Comparative Analysis of Amino Acid Sequences", Critical Reviews in Biochemistry and Molecular Biology 1993, vol. 28, s. 375-430.

\footnotetext{
${ }^{52}$ Por. Koonin and Dolja, ,Evolution and Taxonomy...”.
} 


\section{Endosymbioza}

Hipoteza, że pewne organelle komórek eukariotycznych, zwłaszcza chloroplasty roślin, wyewoluowały z bakterii, nie jest o wiele młodsza od $\mathbf{O}$ powstawaniu gatunków. Zaproponowało ją kilku badaczy pod koniec dziewiętnastego wieku, za podstawę biorąc mikroskopowe badania komórek roślinnych, które ujawniły rzucające się w oczy strukturalne podobieństwo między chloroplastami a sinicami (znanymi wówczas pod nazwą niebiesko-zielonych alg). Hipotezę tę w spójnej formie przedstawił na początku dwudziestego wieku Konstantin Miereżkowski. ${ }^{53}$ Przez pierwsze dwie trzecie dwudziestego wieku hipoteza endosymbiozy uznawana była za spekulację z pogranicza nauki. Ten sposób postrzegania uległ jednak zmianie krótko po opublikowaniu w 1967 roku doniosłej pracy Lynn Sagan (Margulis), która podsumowywała dostępne wówczas dane dotyczące podobieństwa między pewnymi organellami a bakteriami, w szczególności zdumiewające odkrycie genomów organelli. Doszła ona do wniosku, że nie tylko chloroplasty, ale i mitochondria wyewoluowały $z$ endosymbiotycznych bakterii. ${ }^{54}$ Kolejne badania, zwłaszcza filogenetyczna analiza zarówno genów zawartych w mitochondrialnym genomie, jak i genów kodujących białka, które funkcjonują $\mathrm{w}$ mitochondriach i najwyraźniej zostały przetransferowane $\mathrm{z}$ geno$\mathrm{mu}$ mitochondrialnego do jądrowego, przekształciły hipotezę endosymbiozy w dobrze ugruntowany fakt. ${ }^{55}$ Co więcej, te badania filogenetyczne przekonująco wykazały pochodzenie mitochondriów od konkretnej grupy bakterii $\alpha$-proteobakterii. ${ }^{56}$ Wielka rola ewolucyjna przypisywana tak iście unikalnym zdarzeniom jak endosymbioza jest, rzecz jasna, niezgodna zarówno z gradualizmem, jak i uniformitarianizmem.

\footnotetext{
${ }^{53}$ Por. Konstantin MiereżKowski, „Uber Natur und Ursprung der Chromatophoren im Pflanzenreiche”, Biologisches Centralblatt 1905, bd. 25, s. 593-604.

${ }^{54}$ Por. Lynn SAGAN, „On the Origin of Mitosing Cells”, Journal of Theoretical Biology 1967, vol. 14 , s. $255-274$.

${ }^{55}$ Por. Whitney Martin, Meike Hoffmeister, Carmen Rotte, and Katrin Henze, „An Overview of Endosymbiotic Models for the Origins of Eukaryotes, Their ATP-Producing Organelles (Mitochondria and Hydrogenosomes), and Their Heterotrophic Lifestyle", Biological Chemistry 2001, vol. 382, s. 1521-1539.

${ }^{56}$ Por. Michael W. Gray, „The Endosymbiont Hypothesis Revisited”, International Review of Cytology 1992, vol. 141, s. 233-357; Michael W. Gray, Gertraud Burger, and B. Franz Lang, „The Origin and Early Evolution of Mitochondria”, Genome Biology 2001, vol. 2, no. 6.
} 


\section{Biologia ewolucyjna w erze genomiki}

\section{Skarbnica danych genomowych, metagenomowych i postgenomowych}

Podstawowe zasady ewolucji molekularnej ustalono i wielu szczegółowych obserwacji o dużym znaczeniu i wpływie na podstawy neodarwinizmu dokonano w erze przedgenomicznej, a główny argument stanowiła filogeneza oparta na rRNA. Jednak pojawienie się w pełni rozwiniętej techniki sekwencjonowania genomów doprowadziło do jakościowej zmiany w całej biologii ewolucyjnej. Znaczenie ogromnej liczby sekwencji dla analiz porównawczych jest oczywiste, ponieważ materiał ten umożliwia naukowcom badanie mechanizmów i konkretnych zdarzeń ewolucyjnych z niezbędną statystyczną precyzją oraz ukazanie nawet subtelnych trendów ewolucyjnych. Warto ponadto podkreślić, że zbiory różnych w pełni zsekwencjonowanych genomów są niezmiernie przydatne nie tylko ze względu na samą ilość danych na temat sekwencji. Jedynie dzięki porównaniu całych genomów możliwe jest ujednoznacznienie ortologowego (wspólne pochodzenie od jednego ancestralnego genu) i paralogowego (duplikacja genu) związku między genami, przekonujące wykazanie nieobecności danego genu w genomie i zidentyfikowanie zdarzeń utraty genów, a także dokonanie wyczerpującego porównania organizacji genomów oraz rekonstrukcja zdarzeń przeorganizowania genomów. ${ }^{57} \mathrm{Co}$ więcej, w celu zmaksymalizowania korzyści dla biologii ewolucyjnej należy badać przestrzeń genomową zarówno głęboko (czyli uzyskać sekwencje genomów wielu blisko spokrewnionych reprezentantów tego samego taksonu), jak i szeroko (uzyskać sekwencje reprezentatywne dla możliwie największej liczby różnych taksonów). Genomy oddzielone różnymi dystansami ewolucyjnymi są najbardziej odpowiednie dla różnych zadań. Aby na przykład ustalić zakres utrwalenia jakiegoś konkretnego genu lub dokonać rekonstrukcji głównych zdarzeń ewolucyjnych, należy porównać odlegle spokrewnione genomy, natomiast do ilościowej interpretacji procesu selekcji

\footnotetext{
${ }^{57}$ Por. Eugene V. Koonin and Arcady R. Mushegian, „Complete Genome Sequences of Cellular Life Forms: Glimpses of Theoretical Evolutionary Genomics”, Current Opinion in Genetics and Development 1996, vol. 6, s. 757-762; Eugene V. Koonin, Arcady R. Mushegian, and Kenneth E. RudD, „Sequencing and Analysis of Bacterial Genomes”, Current Biology 1996, vol. 6, s. 404 416; Claire M. Fraser, Jonathan A. Eisen, and Steven L. Salzberg, „Microbial Genome Sequencing”, Nature 2000, vol. 406, s. 799-803; Jonathan A. EISEN and Claire M. FraSER, „Phylogenomics: Intersection of Evolution and Genomics”, Science 2003, vol. 300, s. 1706-1707.
} 
oddziałującego na genomy niezbędne są zespoły blisko spokrewnionych genomów. ${ }^{58}$ Do zbioru w pełni zsekwencjonowanych genomów, dostępnego w czasie dwusetnej rocznicy narodzin Darwina, należą tysiące genomów wirusów, blisko 1000 genomów bakterii i archeonów oraz około 100 genomów eukariontów. ${ }^{59}$ Chociaż z pewnością nie wszystkie główne taksony są odpowiednio reprezentowane, to ten szybko rosnący zbiór danych w coraz większym stopniu spełnia wymogi badań mikro- i makroewolucyjnych.

Dopełnieniem osiągnięć tradycyjnej genomiki jest zgromadzony później obszerny zbiór danych metagenomowych. Mimo że metagenomika zwykle nie dostarcza w pełni zsekwencjonowanych genomów, to zapewnia bezcenne informacje na temat różnorodności życia w rozmaitych środowiskach. ${ }^{60}$

Oprócz genomiki i metagenomiki jedną z wizytówek pierwszej dekady nowego tysiąclecia jest postęp badań w dziedzinach genomiki funkcjonalnej i biologii systemowej. Dziedziny te dostarczają wysokojakościowe, obejmujące całe genomy dane na temat ekspresji genów, interakcji genetycznych i interakcji białko-białko, umiejscowienia białek w komórkach i dotyczące wielu innych spraw. Otwiera to nowe wymiary analizy ewolucyjnej, czemu niekiedy nadaje się miano Ewolucyjnej Biologii Systemowej. ${ }^{61}$ To nowe pole badań może dać

\footnotetext{
${ }^{58}$ Por. William C. Nierman, Jonathan A. Eisen, Robert D. Fleischmann, and Claire M. Fraser, „Genome Data: What Do We Learn?”, Current Opinion in Genetics and Development 2000, vol. 10, s. 343-348; James R. Brown, „Genomic and Phylogenetic Perspectives on the Evolution of Prokaryotes”, Systematic Biology 2001, vol. 50, s. 497-512; I. King Jordan, Igor B. Rogozin, Yuri I. Wolf, and Eugene V. Koonin, „Microevolutionary Genomics of Bacteria”, Theoretical Population Biology 2002, vol. 61, s. 435-447; Pavel S. Novichкov, Yuri I. Wolf, Inna DubchaK, and Eugene V. Koonin, „Trends in Prokaryotic Evolution Revealed by Comparison of Closely Related Bacterial and Archaeal Genomes", Journal of Bacteriology 2009, vol. 191, s. 65-73.

${ }^{59}$ Por. Eugene V. Koonin and Yuri I. Wolf, „Genomics of Bacteria and Archaea: The Emerging Dynamic View of the Prokaryotic World", Nucleic Acids Research 2008, vol. 36, s. 66886719; Konstantinos Liolios, Konstantinos Mavromatis, Nektarios Tavernarakis, and Nikos C. Kyrpides, „The Genomes On Line Database (GOLD) in 2007: Status of Genomic and Metagenomic Projects and Their Associated Metadata", Nucleic Acids Research 2008, vol. 36, s. D475D479.

${ }^{60}$ Por. Edward F. DeLong and David M. Kart, „Genomic Perspectives in Microbial Oceanography”, Nature 2005, vol. 437, s. 336-342; David M. KarL, „Microbial Oceanography: Paradigms, Processes and Promise", Nature Reviews Microbiology 2007, vol. 5, s. 759-769.

${ }^{61}$ Por. Mónica Medina, „Genomes, Phylogeny, and Evolutionary Systems Biology”, Proceedings of the National Academy of Sciences USA 2005, vol. 102, suppl. 1, s. 6630-6635; Eu-
} 
nowy wgląd $w$ dotyczące całych genomów związki między ewolucją sekwencji a innymi zmiennymi, takimi jak tempo ekspresji, oraz rzucić światło na selekcyjne i neutralne składniki ewolucji tych aspektów funkcjonowania genomów.

Poniżej podejmę próbę krótkiej syntezy głównych ustaleń genomiki ewolucyjnej, kładąc nacisk na to, jak nowe odkrycia wpływają na centralne zasady biologii ewolucyjnej, w szczególności zwracając uwagę na względny udział procesów selekcyjnych i procesów neutralnych, losowych.

\section{Ewolucyjne utrwalanie sekwencji genów i struktur a płynność budowy genów i architektury genomów}

Zgodnie z fundamentalną obserwacją, potwierdzaną przez całą masę danych zgromadzonych w ramach genomiki ewolucyjnej, sekwencje i struktury genów kodujących białka i strukturalne RNA zostały, na ogół, w wysokim stopniu utrwalone w ogromnych okresach ewolucyjnego czasu. Dzięki aktualnie zgromadzonemu zbiorowi zsekwencjonowanych genomów dla znacznej większości białek zakodowanych w każdym genomie znaleziono ortologi w odległych taksonach. ${ }^{62} \mathrm{Na}$ przykład niedawno uzyskane wyniki sekwencjonowania genomów prymitywnych zwierząt — ukwiała i Trichoplax — ujawniły znaczne utrwalenie repertuaru genów w porównaniu z ssakami lub ptakami, co wskazuje na to, że charakterystyczna długość trwania genów zwierzęcych to między innymi (przynajmniej) setki milionów lat. ${ }^{63}$ Wyniki szeroko zakrojonej analizy porównaw-

gene V. Koonin and Yuri I. Wolf, „Evolutionary Systems Biology: Links Between Gene Evolution and Function", Current Opinion in Biotechnology 2006, vol. 17, s. 481-487; Eugene V. Koonin and Yuri I. Wolf, „Evolutionary Systems Biology”, w: Mark Pagel and Andrew Pomiankowski, (eds.), Evolutionary Genomics and Proteomics, Sinauer Associates, Inc., Sunderland, Massachusetts 2008, s. 11-25.

${ }^{62}$ Por. Eugene V. Koonin and Yuri I. Wolf, „Genomics of Bacteria and Archaea: The Emerging Generalizations After 13 Years”, Nucleic Acids Research 2008, vol. 36, s. 6688-6719.

${ }^{63}$ Por. Nicholas H. Putnam, Mansi Srivastava, Uffe Hellsten, Bill Dirks, Jarrod Chapman, Asaf Salamov, Astrid Terry, Harris Shapiro, Erika A. Lindquist, Vladimir V. Kapitonov et al., „Sea Anemone Genome Reveals Ancestral Eumetazoan Gene Repertoire and Genomic Organization”, Science 2007, vol. 317, s. 86-94; David J. Miller and Eldon E. BALl, „Cryptic Complexity Captured: The Nematostella Genome Reveals Its Secrets", Trends in Genetics 2008, vol. 24, s. 14; Mansi Srivastava, Emina Begovic, Jarrod Chapman, Nicholas H. Putnam, Uffe Hellsten, Takeshi Kawashima, Alan Kuo, Therese Mitros, Asaf Salamov, Meredith L. Carpenter et al., „The Trichoplax Genome and the Nature of Placozoans", Nature 2008, vol. 454, s. 955-960. 
czej genomów roślin, grzybów i prokariontów są w pełni zgodne z tym wnioskiem. ${ }^{64}$ Co więcej, głębokie rekonstrukcje ewolucyjne wskazują, że pierwotne formy setek zachowanych genów występowały już u LUCA. ${ }^{65}$ Konserwatywne rekonstrukcje zbiorów genów wspólnych przodków dwóch domen prokariontów — bakterii i archeonów — zdają się sugerować, że te ancestralne formy, które prawdopodobnie istniały ponad 3 miliardy lat temu, miały porównywalną złożoność genetyczną do, przynajmniej, prostszych, żyjących na swobodzie, współczesnych prokariontów. ${ }^{66} \mathrm{Z}$ perspektywy biologii ewolucyjnej wygląda na to, że sekwencje wielu genów kodujących podstawowe funkcje komórkowe, zwłaszcza translację, transkrypcję, replikację i główne szlaki metaboliczne, podlegały silnemu doborowi oczyszczającemu działającemu w długich odstępach czasu, przy wielu okazjach, w trakcie trwających około 3,5 miliarda lat dziejów komórkowego życia.

Co zadziwiające, nie tylko sekwencje i struktury kodowanych białek, ale i cechy architektury genów niekoniecznie mają bezpośrednie znaczenie dla funkcji genów, które w wysokim stopniu zostały utrwalone w długich okresach dziejów życia. W szczególności pozycje dużej części intronów zostały utrwalone nawet między najbardziej odlegle spokrewnionymi, bogatymi w introny ge-

\footnotetext{
${ }^{64}$ Por. Eugene V. Koonin, Natalie D. Fedorova, John D. Jackson, Aviva R. Jacobs, Dmitri M. Krylov, Kira S. Makarova, Raja Mazumder, Sergei L. Mekhedov, Anastasia N. Nikolskaya, B. Sridhar RAO et al., „A Comprehensive Evolutionary Classification of Proteins Encoded in Complete Eukaryotic Genomes”, Genome Biology 2004, vol. 5, s. R7; Koonin and Wolf, „Genomics of Bacteria and Archaea: The Emerging Generalizations After 13 Years...".

${ }^{65}$ Por. Berend Snel, Peer Bork, and Martjin A. Huynen, „Genomes in Flux: The Evolution of Archaeal and Proteobacterial Gene Content", Genome Research 2002, vol. 12, s. 17-25; Boris G. Mirkin, Trevor I. Fenner, Michael Y. Galperin, and Eugene V. Koonin, „Algorithms for Computing Parsimonious Evolutionary Scenarios for Genome Evolution, the Last Universal Common Ancestor and Dominance of Horizontal Gene Transfer in the Evolution of Prokaryotes", $B M C$ Evolutionary Biology 2003, vol. 3, no. 2; Eugene V. Koonin, „Comparative Genomics, Minimal Gene-Sets and the Last Universal Common Ancestor", Nature Reviews Microbiology 2003, vol. 1, s. 127-136; Victor KunIN and Christos A. Ouzounis, „The Balance of Driving Forces During Genome Evolution in Prokaryotes", Genome Research 2003, vol. 13, s. 1589-1594; Arcady R. Mushegian, „Gene Content of LUCA, the Last Universal Common Ancestor”, Frontiers in Bioscience 2008, vol. 13, s. 4657-4666.

${ }^{66}$ Por. Snel, Bork, and Huynen, „Genomes in Flux...”; Kira S. Makarova, Alexander V. Sorokin, Pavel S. NovichKov, Yuri I. Wolf, and Eugene V. Koonin, „Clusters of Orthologous Genes for 41 Archaeal Genomes and Implications for Evolutionary Genomics of Archaea”, Biology Direct 2007 , vol. 2 , no. 33 .
} 
nomami eukariontów (25-30\% utrwalenia wśród ortologów u roślin i strunowców), ${ }^{67}$ a znaczna większość pozycji intronów jest wspólna ssakom i zwierzętom prymitywnym (basal animals), takim jak Trichoplax i ukwiał. ${ }^{68}$

Uderzający fakt utrwalenia sekwencji i struktur genów kontrastuje z płynnością genowego składu genomów wszystkich form życia, jaki ukazywany jest przez genomikę porównawczą i rekonstrukcje ewolucyjne. Geny (prawie) uniwersalne stanowią tylko niewielką część całego uniwersum genów: w sumie ten centralny rdzeń komórkowego życia składa się co najwyżej z około 70 genów, czyli z nie więcej niż 10\% genów w nawet najmniejszych genomach komórkowych form życia, ale zazwyczaj jest to $1 \%$ genów lub mniej. ${ }^{69}$ Mimo że w każdym poszczególnym genomie większość genów należy do umiarkowanie utrwalonego „pancerza” wspólnego odlegle spokrewnionym organizmom, w całym uniwersum genów geny rdzenia i pancerza (lub precyzyjniej — zbiory genów ortologowych) stanowią niewielką mniejszość. ${ }^{70}$ Zważywszy na tę charakterystyczną strukturę uniwersum genów, rekonstrukcje ewolucyjne nieuchronnie przynoszą dynamiczny obraz ewolucji genomu, w której liczne geny są tracone, a wiele innych jest zyskiwanych wskutek HGT (przeważnie u prokariontów) i duplikacji genów (por. niżej).

\footnotetext{
${ }^{67}$ Por. Alexei Fedorov, Amir F. Merican, and Walter Gilbert, „Largescale Comparison of Intron Positions Among Animal, Plant, and Fungal Genes", Proceedings of the National Academy of Sciences USA 2002, vol. 99, s. 16128-16133; Igor B. Rogozin, Yuri I. Wolf, Alexander V. SoROKIN, Boris G. MIRKIN, and Eugene V. KoonIN, „Remarkable Interkingdom Conservation of Intron Positions and Massive, Lineage-Specific Intron Loss and Gain in Eukaryotic Evolution”, Current Biology 2003, vol. 13, s. 1512-1517; Scott W. Roy and Walter Gilbert, „The Evolution of Spliceosomal Introns: Patterns, Puzzles and Progress”, Nature Reviews Genetics 2006, vol. 7, s. 211 221.

${ }^{68}$ Por. Putnam, Srivastava, Hellsten, Dirks, Chapman, Salamov, Terry, Shapiro, Lindquist, Kapitonov et al., „Sea Anemone Genome...”; SRivastava, Begovic, Chapman, Putnam, Hellsten, Kawashima, Kuo, Mitros, Salamov, Carpenter et al., „The Trichoplax Genome...”.

${ }^{69}$ Por. Koonin, „Comparative Genomics, Minimal Gene-Sets...”; J. Kirk Harris, Scott T. Kelley, George B. Spiegelman, and Norman R. Pace, „The Genetic Core of the Universal Ancestor", Genome Research 2003, vol. 13, s. 407-412; Robert L. Charlebors and W. Ford DooLitTlE, ,Computing Prokaryotic Gene Ubiquity: Rescuing the Core from Extinction”, Genome Research 2004, vol. 14, s. 2469-2477.

${ }^{70}$ Por. Koonin and Wolf, „Genomics of Bacteria and Archaea: The Emerging Generalizations After 13 Years...”.
} 
Architektura genomów, czyli ułożenie genów w genomie, w jeszcze większym stopniu niż genowy skład genomów ukazuje ewolucyjną niestabilność w porównaniu z sekwencjami genów. ${ }^{71} \mathrm{Za}$ wyjątkiem organizacji małych grup funkcjonalnie powiązanych ze sobą genów w operonach, które w pewnych przypadkach wspólne są odlegle spokrewnionym bakteriom i archeonom - prawdopodobnie po części za sprawą szeroko zakrojonego HGT (por. niżej) - obserwujemy na ogół względnie niewielkie utrwalenie porządku genów nawet między blisko spokrewnionymi organizmami. ${ }^{72} \mathrm{~W}$ szczególności u prokariontów dalekosiężne utrwalenie porządku genów zupełnie znika nawet w pewnych grupach blisko spokrewnionych genomów, które zachowują zgodność genów ortologowych niemal jeden do jednego oraz ponad 99\% średnią identyczność sekwencji między ortologowymi białkami. ${ }^{73}$ Tak więc u prokariontów organizacja genów poza poziomem operonów jest, w większości, determinowana rozległym losowym tasowaniem, zwłaszcza przez masowe inwersje, które doprowadziły do powstania procesu replikacji. ${ }^{74}$ Eukarionty wykazują nieco większe utrwalenie dalekosiężnej genomowej syntenii, ale nawet $\mathrm{w}$ tym wypadku istnieje niewiele wspólnych elementów architektury genomów między, na przykład, różnymi typami zwierząt, zaś między królestwami nie występują żadne wspólne elementy. ${ }^{75}$

Zmienność architektur genomów stawia biologów ewolucyjnych przed interesującym dylematem: czy organizmy mają unikalne architektury genomów, które są specjalnie przystosowane do tego, by spełniać unikalne wymogi funk-

\footnotetext{
${ }^{71}$ Por. Eugene V. Koonin, „Evolution of Genome Architecture”, The International Journal of Biochemistry and Cell Biology 2009, vol. 41, s. 298-306.

${ }^{72}$ Por. Arcady R. Mushegian and Eugene V. Koonin, „Gene Order Is Not Conserved in Bacterial Evolution”, Trends in Genetics 1996, vol. 12, s. 289-290; Takeshi Ітон, Кeiko ТАкемото, Нirotada Mori, and Takashi GoJoвori, „Evolutionary Instability of Operon Structures Disclosed by Sequence Comparisons of Complete Microbial Genomes", Molecular Biology and Evolution 1999 , vol. 16, s. 332-346.

${ }^{73}$ Por. Novichkov, Wolf, DubchaK, and Koonin, „Trends in Prokaryotic Evolution...”.

${ }^{74}$ Por. Novichkov, Wolf, Dubchak, and Koonin, „Trends in Prokaryotic Evolution...”; Jonathan A. Eisen, John F. Heidelberg, Owen White, and Steven L. Salzberg, „Evidence for Symmetric Chromosomal Inversions Around the Replication Origin in Bacteria", Genome Biology 2000, vol. 1, RESEARCH0011; Elisabeth R. TILLIER and Richard A. ColLins, „Genome Rearrangement by Replication-Directed Translocation”, Nature Genetics 2000, vol. 26, s. 195-197.

${ }^{75}$ Por. Koonin, „Evolution of Genome Architecture...”.
} 
cjonalne odpowiednich organizmów, czy też ewolucja architektury genomów jest w większości procesem neutralnym? Chociaż wielokrotnie obserwowano lokalne zgrupowania funkcjonalnie powiązanych ze sobą genów oraz inne wzorce wskazujące na istotną pod względem funkcjonalnym współekspresję genów, trendy te są względnie słabe i wcale nie powszechne. ${ }^{76}$ Tak więc wygląda na to, że dominującym czynnikiem w ewolucji architektury genomów jest losowa, nieadaptacyjna reorganizacja, nie zaś dobór oczyszczający lub pozytywny.

\section{Horyzontalny transfer genów, sieć ewolucji i las w miejsce drzewa życia}

Jeszcze na długo przed nadejściem ery genomicznej mikrobiologowie zdali sobie sprawę z tego, że bakterie mają zdolność wymiany informacji genetycznej drogą HGT, co prowadzi w pewnych przypadkach do skutków o wielkim znaczeniu, na przykład do odporności na antybiotyki. ${ }^{77}$ Odkryto wiele molekularnych mechanizmów HGT, w tym wymianę plazmidów, transdukcję (HGT realizowany przez bakteriofagi) i transformację. ${ }^{78}$ Pomimo tych odkryć, HGT postrzegany był na ogół jako zjawisko o niewielkiej wadze, istotne tylko w szczególnych okolicznościach, a w każdym razie nie uważano, by zagrażało ono koncepcji drzewa życia możliwego do zrekonstruowania dzięki filogenetycznej analizie rRNA i innych utrwalonych genów. To fundamentalne przekonanie zachwiało się w posadach za sprawą wczesnych wyników analizy porównawczej genomów bakterii i archeonów, wskazujących, że - przynajmniej w genomach pewnych prokariontów - duża część genów ewidentnie została nabyta drogą HGT. Doskonały tego przykład stanowią wyspy patogenności i podobne wyspy symbiotyczne, tworzące ponad $30 \%$ genomu wielu patogennych i symbiotycz-

\footnotetext{
${ }^{76}$ Por. Jeffrey G. Lawrence, „Gene Organization: Selection, Selfishness, and Serendipity”, Annual Review of Microbiology 2003, vol. 57, s. 419-440; Laurence D. HuRst, Csaba PÁL, and Martin J. LeRChER, „The Evolutionary Dynamics of Eukaryotic Gene Order”, Nature Reviews Genetics 2004, vol. 5, s. 299-310.

${ }^{77}$ Por. Michael Syvanen and Clarence I. Kado (eds.), Horizontal Gene Transfer, Academic Press, San Diego 2002.

${ }^{78}$ Por. Frederic Bushman, Lateral DNA Transfer: Mechanisms and Consequences, Cold Spring Harbor Laboratory Press, Cold Spring Harbor, New York 2001.
} 
nych bakterii. ${ }^{79}$ Co więcej, analiza porównawcza genomów hipertermofilnych bakterii i archeonów wskazuje, że nawet międzydomenowy HGT może mieć szeroki zakres przez wzgląd na wspólne siedliska. ${ }^{80}$

Jednoznaczne wykazanie działania HGT, a zwłaszcza odróżnienie go od masowej utraty genów, może sprawiać trudności i w związku z tym zakres poziomej mobilności genów między prokariontami nadal stanowi przedmiot dyskusji. ${ }^{81}$ Niemniej w miarę powiększania się genomowej bazy danych obszerne analizy w ramach genomiki porównawczej $\mathrm{i}$ analizy filogenetyczne dają coraz większe podstawy dla wniosku, że HGT jest właściwie wszechobecny w świecie prokariontów - w tym sensie, że jest bardzo mało (lub nie ma żadnych) zbiorów genów ortologowych, których dzieje nie wykazują udziału HGT. ${ }^{82}$ Tempo HGT znacznie różni się w przypadku różnych genów w zależności od ich funkcji, po części - jak głosi tak zwana hipoteza złożoności postulująca, że mogą istnieć bariery dla horyzontalnego transferu genów kodujących podjednostki kompleksów białkowych — z tego powodu, że skutki takich zdarzeń, to jest nierównowaga dawkowania oraz mieszanie heterologowych podjednostek, mogą

\footnotetext{
${ }^{79}$ Por. Jörg H. HACKer and James B. KAPER, „Pathogenicity Islands and the Evolution of Microbes”, Annual Review of Microbiology 2000, vol. 54, s. 641-679; Howard Ochman and Nancy A. Moran, „Genes Lost and Genes Found: Evolution of Bacterial Pathogenesis and Symbiosis”, Science 2001, vol. 292, s. 1096-1099; Nicole T. Perna, Guy Plunkett III, Valerie Burland, Bob Mau, Jeremy D. Glasner, Debra J. Rose, George F. Mayhew, Peter S. Evans, Jason Gregor, Heather A. KIRKPATRICK et al., „Genome Sequence of Enterohaemorrhagic Escherichia coli O157: H7", Nature 2001, vol. 409, s. 529-533.

${ }^{80}$ Por. L. Aravind, Roman L. Tatusov, Yuri I. Wolf, D.R. Walker, and Eugene V. Koonin, „Evidence for Massive Gene Exchange Between Archaeal and Bacterial Hyperthermophiles”, Trends in Genetics 1998, vol. 14, s. 442-444; Karen E. Nelson, Rebecca A. Clayton, Steven R. Gill, Michelle L. Gwinn, Robert J. Dodson, Daniel H. Haft, Erin K. Hickey, Jeremy D. Peterson, William C. Nelson, Karen A. Ketchum et al., „Evidence for Lateral Gene Transfer Between Archaea and Bacteria from Genome Sequence of Thermotoga maritima", Nature 1999, vol. 399, s. 323-329.

${ }^{81}$ Por. Jeffrey G. Lawrence and Heather L. Hendrickson, „Lateral Gene Transfer: When Will Adolescence End?”, Molecular Microbiology 2003, vol. 50, s. 739-749; Eugene V. Koonin, „Horizontal Gene Transfer: The Path to Maturity", Molecular Microbiology 2003, vol. 50, s. 725-727; Charles G. Kurland, Björn Canbäck, and Otto G. Berg, „Horizontal Gene Transfer: A Critical View”, Proceedings of the National Academy of Sciences USA 2003, vol. 100, s. 9658-9662.

${ }^{82}$ Por. J. Peter Gogarten, W. Ford Doolittle, and Jeffrey G. Lawrence, „Prokaryotic Evolution in Light of Gene Transfer", Molecular Biology and Evolution 2002, vol. 19, s. 2226-2238; J. Peter Gogarten and Jeffrey P. Townsend, „Horizontal Gene Transfer, Genome Innovation and Evolution", Nature Reviews Microbiology 2005, vol. 3, s. 679-687.
} 
być szkodliwe. ${ }^{83}$ Analizy filogenetyczne wskazują jednak, że nawet takie geny - na przykład geny kodujące białka rybosomalne i podjednostki polimerazy RNA — nie są zabezpieczone przed HGT. ${ }^{84}$

Zgodnie z hipotezą samolubnego operonu duża przewaga HGT u prokariontów może, po części, wyjaśnić utrzymywanie się organizacji wielu operonów w szerokim zakresie organizmów. ${ }^{85}$ Chociaż operony mogą być początkowo selekcjonowane ze względu na korzystną współekspresję i współregulację genów powiązanych $z$ jakimś funkcjami, najpewniej są one utrzymywane i rozpowszechniane $\mathrm{w}$ świecie prokariontów z uwagi na zwiększone prawdopodobieństwo utrwalenia operonu na skutek HGT w porównaniu z, na przykład, parą genów nieoperonowych. Scenariusz ten przedstawia znakomity przykład kombinacji sił selekcyjnych (współregulacja) i neutralnych (HGT), które odgrywają rolę w ewolucji ważnego aspektu organizacji genomu. ${ }^{86}$

Eukarionty różnią się od prokariontów pod względem roli, jaką odgrywa HGT w ewolucji genomów. U eukariontów wielokomórkowych, u których komórki linii zarodkowej różnią się od somy, HGT wydaje się zjawiskiem rzad-

\footnotetext{
${ }^{83}$ Por. Ravi JaIn, Maria C. Rivera, and James A. LaKe, „Horizontal Gene Transfer Among Genomes: The Complexity Hypothesis", Proceedings of the National Academy of Sciences USA 1999, vol. 96, s. 3801-3806; Alon Wellner, Mor N. Lurie, and Uri Gophna, „Complexity, Connectivity, and Duplicability as Barriers to Lateral Gene Transfer", Genome Biology 2007, vol. 8, s. R156.

${ }^{84}$ Por. Corinne Brochier, Hene’ PhilipPe, and Débora Regina de Melo Moreira, „The Evolutionary History of Ribosomal Protein RpS14: Horizontal Gene Transfer at the Heart of the Ribosome”, Trends in Genetics 2000, vol. 16, s. 529-533; Kira S. MaKarova, V.A. Ponomarev, and Eugene V. Koonin, „Two C Or Not Two C: Recurrent Disruption of Zn-Ribbons, Gene Duplication, Lineage-Specific Gene Loss, and Horizontal Gene Transfer in Evolution of Bacterial Ribosomal Proteins", Genome Biology 2001, vol. 2, RESEARCH0033; Lakshminarayan M. IYER, Eugene V. Koonin, and L. Aravind, „Evolution of Bacterial RNA Polymerase: Implications for LargeScale Bacterial Phylogeny, Domain Accretion, and Horizontal Gene Transfer", Gene 2004, vol. 335, s. 73-88.

${ }^{85}$ Por. Jeffrey G. Lawrence, „Selfish Operons: The Evolutionary Impact of Gene Clustering in Prokaryotes and Eukaryotes", Current Opinion in Genetics and Development 1999, vol. 9, s. 642-648; Jeffrey G. Lawrence, „Selfish Operons and Speciation by Gene Transfer”, Trends in Microbiology 1997, vol. 5, s. 355-359.
}

${ }^{86}$ Por. Koonin and Wolf, „Genomics of Bacteria and Archaea: The Emerging Dynamic View of the Prokaryotic World...”; Lawrence, „Gene Organization...”. 
kim, ${ }^{87}$ aczkolwiek nie niemożliwym. ${ }^{88} \mathrm{~W}$ pewnych szczególnych okolicznościach, takich jak stałe występowanie endosymbiotycznych bakterii u zwierząt, transfer dużych odcinków genomów bakteryjnych do genomów gospodarza okazuje się zjawiskiem powszechnym. ${ }^{89}$ Wygląda na to, że eukarionty jednokomórkowe uzyskują geny bakteryjne i wymieniają geny między sobą względnie często. ${ }^{90}$ Znacznie ważniejszy jest jednak duży wkład genomów endosymbiontów do zestawów genów wszystkich eukariontów. Odkrycie organelli przypominających mitochondria i genów o wyraźnie mitochondrialnym pochodzeniu u wszystkich gruntownie opisanych jednokomórkowych eukariontów zasadniczo upewnia nas, że ostatni wspólny przodek ocalałych eukariontów miał już mitochondrialnego endosymbionta. ${ }^{91}$ Mając na względzie ich wyraźne filogenetyczne powinowactwa, eukariotyczne geny z łatwo rozpoznawalnymi prokariotycznymi ortologami można wyraźnie podzielić na geny o prawdopodobnym

\footnotetext{
${ }^{87}$ Por. Jan O. Andersson, „Lateral Gene Transfer in Eukaryotes”, Cellular and Molecular Life Sciences 2005, vol. 62, s. 1182-1197.

${ }^{88}$ Por. Fyodor A. Kondrashov, Eugene V. Koonin, Igor G. Morgunov, Tatiana V. Finogenova, and Marie N. Kondrashova, „Evolution of Glyoxylate Cycle Enzymes in Metazoa: Evidence of Multiple Horizontal Transfer Events and Pseudogene Formation”, Biology Direct 2006, vol. 1, no. 31.

${ }^{89}$ Por. Julie C. Dunning Hotopp, Michael E. Clark, Deodoro C.S.G. Oliveira, Jeremy M. Foster, Peter Fischer, Mónica C. Muñoz Torres, Jonathan D. Giebel, Nikhil Kumar, Nadeeza Ishmael, Shiliang WANG et al., „Widespread Lateral Gene Transfer from Intracellular Bacteria to Multicellular Eukaryotes", Science 2007, vol. 317, s. 1753-1756; Naruo Niкoh, Kohjiro TanaKa, Fukashi Shibata, Natsuko Ito Kondo, Masahiro Hizume, Masakazu Shimada, and Takema Fukatsu, ,Wolbachia Genome Integrated in an Insect Chromosome: Evolution and Fate of Laterally Transferred Endosymbiont Genes", Genome Research 2008, vol. 18, s. 272-280.

${ }^{90}$ Por. Anoek P. de Koning, Fiona S.L. Brinkman, Steven J.M. Jones, and Patrick J. Keeling, „Lateral Gene Transfer and Metabolic Adaptation in the Human Parasite Trichomonas vaginalis”, Molecular Biology and Evolution 2000, vol. 17, s. 1769-1773; Matthew B. Rogers, Russell F. Watkins, James T. Harper, Dion G. Durnford, Michael W. Gray, and Patrick J. Keeling, „A Complex and Punctate Distribution of Three Eukaryotic Genes Derived by Lateral Gene Transfer”, BMC Evolutionary Biology 2007, vol. 7, no. 89; Jan O. Andersson, Åsa SJögren, David S. Horner, Colleen A. Murphy, Patricia L. Dyal, Staffan G. Svärd, John M. Logsdon, Jr., Mark A. Ragan, Robert P. HiRT, and Andrew J. Roger, „A Genomic Survey of the Fish Parasite Spironucleus salmonicida Indicates Genomic Plasticity Among Diplomonads and Significant Lateral Gene Transfer in Eukaryote Genome Evolution”, BMC Genomics 2007, vol. 8, no. 51.

${ }^{91}$ Por. T. Martin Embley, „Multiple Secondary Origins of the Anaerobic Lifestyle in Eukaryotes", Philosophical Transactions of the Royal Society of London B: Biological Sciences 2006, vol. 361, s. 1055-1067; T. Martin EmBley and William MarTin, „Eukaryotic Evolution, Changes and Challenges", Nature 2006, vol. 440, s. 623-630.
} 
pochodzeniu od archeonów (głównie, choć nie wyłącznie, są to składniki układów przetwarzających informacje) oraz geny o prawdopodobnym pochodzeniu od bakterii (w większości enzymy metaboliczne i elementy różnych struktur komórkowych). ${ }^{92}$ Często czyni się ogólne założenie, że większość ancestralnych „bakteryjnych” genów u eukariontów ma pochodzenie mitochondrialne, ale trudno wykazać to bezpośrednio, ponieważ zgodnie z wynikami analizy filogenetycznej geny te związane są z różnymi grupami bakterii. ${ }^{93}$ Ustalenia te niełatwo jest interpretować, gdyż składy genów endosymbionta i jego gospodarza nie są znane i jest możliwe, że jeden $z$ nich lub oba mogły już zgromadzić liczne geny z różnych źródeł. ${ }^{94}$ Jeszcze bardziej niepewny jest rzeczywisty scenariusz powstania eukariontów (szczegółowe omówienie tego ważnego tematu wykracza poza zakres niniejszego artykułu ${ }^{95}$ ). Krótko mówiąc, rywalizujące i gorąco dyskutowane hipotezy są następujące:

i. Scenariusz symbiogenetyczny, zgodnie z którym $\alpha$-proteobakteryjny przodek mitochondriów zaatakował gospodarza będącego archeonem i zdarzenie to uruchomiło proces genezy eukariontów, w tym uformowanie się charakterystycznych cech strukturalnych komórki eukariotycznej, takich jak układ błon wewnętrznych, cytoszkielet i jądro. ${ }^{96}$

\footnotetext{
${ }^{92}$ Por. Christian Esser, Nahal Ahmadinejad, Christian Wiegand, Carmen Rotte, Federico L. Sebastiani, Gabriel Gelius-Dietrich, Katrin Henze, Ernst Kretschmann, Erik Richly, Dario LeiSter et al., „A Genome Phylogeny for Mitochondria Among Alpha-Proteobacteria and a Predominantly Eubacterial Ancestry of Yeast Nuclear Genes", Molecular Biology and Evolution 2004, vol. 21, s. 1643-1660; Natalya Yutin, Kira S. Makarova, Sergey L. Mekhedov, Yuri I. Wolf, and Eugene V. Koonin, „The Deep Archaeal Roots of Eukaryotes”, Molecular Biology and Evolution 2008, vol. 25, s. 1619-1630.

${ }^{93}$ Por. Esser, Ahmadinejad, Wiegand, Rotte, Sebastiani, Gelius-Dietrich, Henze, Kretschmann, Richly, Leister et al., „A Genome Phylogeny for Mitochondria...”.

${ }^{94}$ Por. Christian Esser, William Martin, and Tal DAGAN, „The Origin of Mitochondria in Light of a Fluid Prokaryotic Chromosome Model”, Biology Letters 2007, vol. 3, s. 180-184.

${ }^{95} \mathrm{~W}$ tej sprawie por. najnowsze artykuły przeglądowe i dyskusje: EMBLEY and MARTin, „Eukaryotic Evolution...”; Charles G. Kurland, Laura J. Collins, and David Penny, „Genomics and the Irreducible Nature of Eukaryote Cells", Science 2006, vol. 312, s. 1011-1014; William MarTiN and Eugene V. Koonin, „Introns and the Origin of Nucleus-Cytosol Compartmentation”, Nature 2006, vol. 440, s. 41-45; Anthony M. Poole and David Penny, „Evaluating Hypotheses for the Origin of Eukaryotes”, BioEssays 2007, vol. 29, s. 74-84; Tal DAGAN and William MARTIN, „Testing Hypotheses Without Considering Predictions", BioEssays 2007, vol. 29, s. 500-503.
}

${ }^{96}$ Por. Martin and Koonin, „Introns...”; William Martin and Miklós Müller, „The Hydrogen 
ii. Scenariusz mówiący o archezoa, wedle którego gospodarzem mitochondrialnego endosymbionta był prymitywny eukariont posiadający już wszystkie główne cechy komórki eukariotycznej, które wyewoluowały zupełnie niezależnie od endosymbiozy, ale ułatwiły ją dzięki fagocytowemu potencjałowi tego protoeukarionta. ${ }^{97}$

Niezależnie od dokładnej roli odgrywanej przez endosymbiozę w eukariogenezie, nie ma poważnych wątpliwości co do tego, że zestaw genów eukariontów stanowi chimerę złożoną z funkcjonalnie odrębnych genów pochodzących od archeonów i bakterii. ${ }^{98}$ Ponadto endosymbioza najwyraźniej miała znaczny wkład do zestawów genów niektórych indywidualnych, dużych grup eukariontów. Przedstawiono mocne świadectwa masowego HGT tysięcy genów z endosymbionta należącego do sinic (chloroplastu) do genomów (roślinnych) gospodarzy. ${ }^{99}$ Podobnie geny wyraźnie pochodzące od alg wykryto u Chromalveolata, które pochłonęły czerwone algi w akcie wtórnej endosymbiozy. ${ }^{100}$

Obserwacje opisanego wyżej masowego, wszechobecnego, zachodzącego wieloma drogami HGT prowadzą do podstawowego uogólnienia: genomy wszystkich form życia są zbiorami genów o różnych historiach ewolucyjnych. Następstwem tej generalizacji jest to, że koncepcję drzewa życia należy zasadniczo zrewidować lub porzucić, ponieważ topologia pojedynczego drzewa lub nawet odpowiednie topologie drzew dla wysoce utrwalonych genów prawdopodobnie nie mogą przedstawiać historii wszystkich czy choćby większości ge-

Hypothesis for the First Eukaryote", Nature 1998, vol. 392, s. 37-41.

${ }^{97}$ Por. Kurland, Collins, and Penny, „Genomics and the Irreducible Nature...”; Anthony Poole and David Penny, „Eukaryote Evolution: Engulfed by Speculation”, Nature 2007, vol. 447, s. 913.

${ }^{98}$ Por. Esser, Ahmadinejad, Wiegand, Rotte, Sebastiani, Gelius-Dietrich, Henze, Kretschmann, Richly, Leister et al., „A Genome Phylogeny for Mitochondria...”; Maria C. Rivera and James A. LaKe, „The Ring of Life Provides Evidence for a Genome Fusion Origin of Eukaryotes”, Nature 2004, vol. 431, s. 152-155.

${ }^{99}$ Por. William Martin, Tamas Rujan, Erik Richly, Andrea Hansen, Sabine Cornelsen, Thomas Lins, Dario Leister, Bettina Stoebe, Masami Hasegawa, and David Penny, „Evolutionary Analysis of Arabidopsis, Cyanobacterial, and Chloroplast Genomes Reveals Plastid Phylogeny and Thousands of Cyanobacterial Genes in the Nucleus", Proceedings of the National Academy of Sciences USA 2002, vol. 99, s. 12246-12251.

${ }^{100}$ Por. Tetyana Nosenko and Debashish Bhattacharya, „Horizontal Gene Transfer in Chromalveolates", BMC Evolutionary Biology 2007, vol. 7, no. 173. 
nów. ${ }^{101}$ Adekwatnym przedstawieniem dziejów życia jest więc raczej sieć wymian genów niż pojedyncze drzewo, a tym samym wyniki uzyskiwane przez genomikę porównawczą falsyfikują „mocną" hipotezę drzewa życia mówiącą o istnieniu „drzewa gatunkowego” dla całych dziejów życia komórkowego.

$\mathrm{Z}$ pewnością wniosku tego nie należy uznawać za równoznaczny z tezą, że wprowadzona przez Darwina koncepcja drzewa ewolucji ${ }^{102}$ powinna zostać całkowicie zarzucona. Po pierwsze, drzewa mogą zapewniać adekwatne ilustracje ewolucji pojedynczych rodzin genów. Po drugie, ponad wszelką wątpliwość istnieją ekspansywne okresy dziejów życia, w przypadku których można otrzymać stosowne drzewa dla dużych zbiorów genów ortologowych, a tym samym spójną topologię tych drzew można uznać za drzewo gatunkowe. Ewolucja głównych grup eukariontów, takich jak zwierzęta lub rośliny, jest przykładem najoczywistszym, ale ewolucja drzewopodobna miała najwyraźniej miejsce również w przypadku wielu grup prokariontów na względnie niskich poziomach filogenetycznych. Otwarta pozostaje kwestia, czy całą ewolucję życia najlepiej przedstawić jako:

i. spójne drzewo wysoce utrwalonych genów, reprezentujące „główny trend" ewolucji, w połączeniu z występowaniem HGT - także masowym HGT, któremu towarzyszyła endosymbioza — prezentującym poziome połączenia między gałęziami drzewa (por. rysunek 1A), ${ }^{103}$ lub

ii. skomplikowaną sieć, w której fazy ewolucji drzewopodobnej (z poziomymi połączeniami) są poprzeplatane fazami „Wielkiego Wybuchu”, czyli gwałtownej horyzontalnej wymiany informacji genetycznej, których już w samej zasadzie nie da się zaprezentować jako drzew (por. ry-

${ }^{101}$ Por. W. Ford Doolitrle, „Phylogenetic Classification and the Universal Tree”, Science 1999, vol. 284, s. 2124-2129; Eric Bapteste, Edward Susko, Jessica W. Leigh, Dave MacLeod, Robert L. Charlebois, and W. Ford Doolittle, „Do Orthologous Gene Phylogenies Really Support Tree-Thinking?", BMC Evolutionary Biology 2005, vol. 5, no. 33; Tal DAGAN and William F. Martin, „The Tree of One Percent”, Genome Biology 2006, vol. 7, no. 118; W. Ford Doolittle and Eric Bapteste, „Pattern Pluralism and the Tree of Life Hypothesis”, Proceedings of the National Academy of Sciences USA 2007, vol. 104, s. 2043-2049.

${ }^{102}$ Por. DARwin, O powstawaniu gatunków..., s. 108.

${ }^{103}$ Por. Yuri I. Wolf, Igor B. Rogozin, Nick V. Grishin, and Eugene V. Koonin, „Genome Trees and the Tree of Life", Trends in Genetics 2002, vol. 18, s. 472-479. 
sunek 1B). ${ }^{104}$

A

B

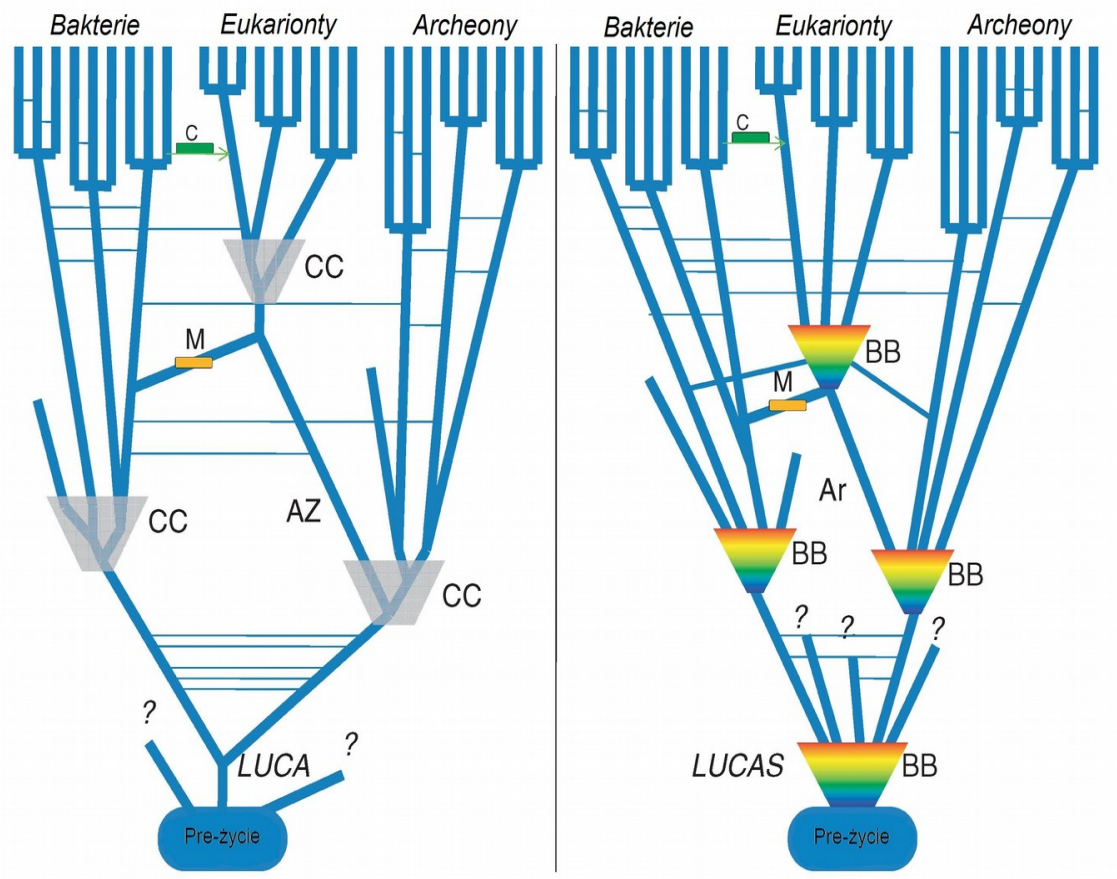

Rys. 1. Dwa poglądy na dzieje życia jako alternatywy dla hipotezy drzewa życia. (A) Model „drzewa życia jako głównego trendu”. Dzieje życia przedstawione są w formie drzewa z liniami łączącymi gałęzie ilustrującymi HGT oraz szarymi trapezami ilustrującymi fazy skróconej kladogenezy. ${ }^{105}$ Powstanie eukariontów przedstawione jest zgodnie z hipotezą o archezoa, w myśl której gospodarzem mitochondrialnego endosymbionta był protoeukariont (archezoa). Przewiduje się istnienie komórkowego Ostatniego Uniwersalnego Wspólnego Przodka (LUCA). (B) Model „Wielkiego Wybuchu”. Dzieje życia przedstawione w postaci sukcesji drzewopodobnych faz, którym towarzyszy HGT, oraz niedrzewopodobnych faz Wielkiego Wybuchu. Linie łączące gałęzie drzew ilustrują HGT, a kolorowe trapezy - fazy Wielkiego Wybuchu. ${ }^{106}$ Powstanie eukariontów przedstawione jest zgodnie z modelem symbiogenezy, w świetle

${ }^{104}$ Por. Eugene V. Koonin, „The Biological Big Bang Model for the Major Transitions in Evolution", Biology Direct 2007, vol. 2, no. 21.

${ }^{105}$ Por. Antonis RoKas and Sean B. CArroll, „Bushes in the Tree of Life”, PLoS Biology 2006, vol. 4, e352.

${ }^{106}$ Por. Koonin, „The Biological Big Bang Model...”. 
którego gospodarzem mitochondrialnego endosymbionta był archeon. Przewiduje się istnienie przedkomórkowego Ostatniego Uniwersalnego Wspólnego Stanu Ancestralnego (LUCAS - Last Universal Common Ancestral State). Ar, archeon (gospodarz mitochondrium w B); AZ, archezoa (gospodarz mitochondrium w A); BB, Wielki Wybuch (Big Bang); C, chloroplast; CC, skrócona kladogeneza (compressed cladogenesis); M, mitochondrium.

\section{Metagenomika, rozszerzający się świat samolubnych replikonów i ich fuzja}

Metagenomika to ważny nowy kierunek badań genomicznych, którego celem jest (zwykle, na tym etapie, częściowe) zsekwencjonowanie genomów wszystkich form życia zajmujących pewne siedlisko. Metagenomika, mimo że jest to młoda dziedzina, już może pochwalić się dużymi osiągnięciami w charakteryzowaniu różnorodności bakterii $\mathrm{w}$ różnych siedliskach, szczególnie w oceanach. ${ }^{107}$ Kierunkiem, który w moim przekonaniu ma szczególne konceptualne znaczenie dla biologii ewolucyjnej, jest metagenomika wirusów. ${ }^{108}$ Znamiennym wnioskiem płynącym $\mathrm{z}$ różnych metagenomicznych badań wirusów jest to, że przynajmniej w niektórych, zwłaszcza morskich, siedliskach wirusy (bakteriofagi) są najliczniejszymi istotami biologicznymi, przy czym liczba cząsteczek wirusowych przewyższa liczbę komórek o rząd wielkości. ${ }^{109}$ Mimo że genomy wirusów są małe w porównaniu do genomów komórkowych form życia, wyniki badań metagenomicznych wskazują, że genomy wirusów stanowią dużą część genetycznego uniwersum, które jest co najmniej porównywalne roz-

\footnotetext{
${ }^{107}$ Por. Martin Langer, Esther M. Gabor, Klaus Liebeton, Guido Meurer, Frank Niehaus, Renate Schulze, Jürgen Eck, and Patrick Lorenz, „Metagenomics: An Inexhaustible Access to Nature's Diversity”, Biotechnology Journal 2006, vol. 1, s. 815-821; Susannah G. TRINGE, Christian von Mering, Arthur Kobayashi, Asaf A. Salamov, Kevin Chen, Hwai W. Chang, Mircea Podar, Jay M. Short, Eric J. Mathur, J. Chris Detter et al., „Comparative Metagenomics of Microbial Communities", Science 2005, vol. 308, s. 554-557; Shibu Yooseph, Granger Sutton, Douglas B. Rusch, Aaron L. Halpern, Shannon J. Williamson, Karin Remington, Jonathan A. Eisen, Karla B. HeidelBerg, Gerard Manning, Weizhong Li et al., „The Sorcerer II Global Ocean Sampling Expedition: Expanding the Universe of Protein Families", PLoS Biology 2007, vol. 5, e16.

${ }^{108}$ Por. Eric L. Delwart, „Viral Metagenomics”, Reviews in Medical Virology 2007, vol. 17, s. $115-131$.

${ }^{109}$ Por. Florent E. Angly, Ben Felts, Mya Breitbart, Peter Salamon, Robert A. Edwards, Craig Carlson, Amy M. Chan, Matthew Haynes, Scott Kelley, Hong Liu et al., „The Marine Viromes of Four Oceanic Regions", PLoS Biology 2006, vol. 4, e368; Robert A. EdwARDS and Forest RoHwer, „Viral Metagenomics”, Nature Reviews Microbiology 2005, vol. 3, s. 504-510.
} 
miarami do części zajmowanej przez genomy organizmów komórkowych. Co więcej, zważywszy na to, że w przypadku wirusów o dużych genomach znaczna część genów nie posiada wykrywalnych homologów w aktualnych bazach danych sekwencji, ${ }^{110}$ najprawdopodobniejsze wydaje się, że wirusy stanowią większą część różnorodności genetycznej na tej planecie. Ustalenia te współgrają z faktem dużej dominacji różnych klas elementów ruchomych w genomach wielu organizmów komórkowych. W istocie w genomach ssaków sekwencje będące pochodnymi elementów ruchomych, głównie retrotranspozonów (SINE i LINE), stanowią przynajmniej 40\% genomowego DNA. ${ }^{111}$

Wirusy i różne inne samolubne replikony (definiowane jako elementy genetyczne, które nie kodują kompletnego systemu translacji), takie jak rozmaite plazmidy i transpozony, tworzą powiązaną pulę genetyczną zwaną mobilomem, wirosferą lub światem wirusów. ${ }^{112}$ Tożsamość świata wirusów przejawia się w istnieniu zbioru „charakterystycznych genów”, które kodują białka o kluczowych rolach w reprodukcji samolubnych elementów (włącznie $\mathrm{z}$ wirusowymi białkami kapsydu) i występują w skrajnie różnych elementach rozpowszechnionych w szerokim wachlarzu gospodarzy, lecz nie w komórkowych formach życia. Istnienie odrębnej puli charakterystycznych genów obejmującej między innymi zależną od RNA polimerazę RNA i DNA, to jest enzymy replikacji, które prawdopodobnie istniały wcześniej niż duże genomy DNA, silnie wskazuje na to, że świat wirusów współwystępował z komórkowymi formami życia przez

\footnotetext{
${ }^{110}$ Por. Lakshminarayan M. Iyer, Sandhiya Balaj, Eugene V. Koonin, and L. Aravind, „Evolutionary Genomics of Nucleo-Cytoplasmic Large DNA Viruses", Virus Research 2006, vol. 117, s. 156-184; David Prangishvili, Roger A. Garrett, and Eugene V. Koonin, „Evolutionary Genomics of Archaeal Viruses: Unique Viral Genomes in the Third Domain of Life", Virus Research 2006, vol. 117, s. 52-67; Galina Glazko, Vladimir Makarenkov, Jing Liu, and Arcady MuSHEGIAN, „Evolutionary History of Bacteriophages with Double-Stranded DNA Genomes”, Biology Direct 2007, vol. 2, no. 36.

${ }^{111}$ Por. John L. Goodier and Haig H. KazAZIan, Jr., „Retrotransposons Revisited: The Restraint and Rehabilitation of Parasites", Cell 2008, vol. 135, s. 23-35.

${ }^{112}$ Por. Koonin and Wolf, „Genomics of Bacteria and Archaea: The Emerging Dynamic View of the Prokaryotic World...”; Laura S. Frost, Raphael Leplae, Anne O. Summers, and Ariane Toussaint, „Mobile Genetic Elements: The Agents of Open Source Evolution”, Nature Reviews Microbiology 2005, vol. 3, s. 722-732; Patrick ForTerre, „The Origin of Viruses and Their Possible Roles in Major Evolutionary Transitions”, Virus Research 2006, vol. 117, s. 5-16; Eugene V. Koonin, Tatiana G. Senkevich, and Valerian V. Dolja, „The Ancient Virus World and Evolution of Cells", Biology Direct 2006, vol. 1, no. 29.
} 
całe ich dzieje i być może wywodzi się z pierwotnej, przedkomórkowej puli elementów genetycznych. ${ }^{113}$

Pomimo swej odrębności, świat wirusów nieustannie wchodzi w interakcje z pulą genomową komórkowych form życia, na co wskazuje ciągły ruch genów między przenoszonymi bakteriofagami, plazmidami i chromosomami bakteryjnymi ${ }^{114}$ lub przechwytywanie genów komórkowych (protoonkogenów) przez zwierzęce retrowirusy. ${ }^{115}$ Niedawne obserwacje przeprowadzanego przez bakteriofagi transferu genów między odlegle spokrewnionymi bakteriami, nawet bez rozpowszechnienia faga w organizmie będącym biorcą, wskazuje, że przepływ genów przeprowadzany przez samolubne replikony może być zjawiskiem znacznie powszechniejszym niż dotąd przypuszczano. ${ }^{116}$ Co ważne, części elementów ruchomych są często werbowane (ulegają egzaptacji) przez geny gospodarzy jako elementy regulatorowe, ${ }^{117}$ a w niektórych przypadkach jako części sekwencji kodujących białka. ${ }^{118}$ Znane są też indywidualne przypadki egzaptacji kompletnych genów z elementów ruchomych, co dobitnie ilustruje ewolucja genu hedgehog, kluczowego regulatora rozwoju zwierząt, z inteiny. ${ }^{119}$

\footnotetext{
${ }^{113}$ Por. Koonin, Senkevich, and Dolja, „The Ancient Virus World...”.

${ }^{114}$ Por. Koonin and Wolf, „Genomics of Bacteria and Archaea: The Emerging Generalizations After 13 Years...".

${ }^{115}$ Por. Amanda Swain and John M. Coffin, „Mechanism of Transduction by Retroviruses”, Science 1992, vol. 255, s. 841-845.

${ }^{116}$ Por. John Xi Chen and Richard P. Novick, „Phage-Mediated Intergeneric Transfer of Toxin Genes", Science 2009, vol. 323, s. 139-141.

${ }^{117}$ Por. I. King Jordan, Igor B. Rogozin, Galina V. Glazko, and Eugene V. Koonin, „Origin of a Substantial Fraction of Human Regulatory Sequences from Transposable Elements", Trends in Genetics 2003, vol. 19, s. 68-72; Nalini Polavarapu, Leonardo Mariño-Ramírez, David Landsman, Jonh F. McDonald, and I. King Jordan, „Evolutionary Rates and Patterns for Human Transcription Factor Binding Sites Derived from Repetitive DNA”, BMC Genomics 2008, vol. 9, no. 226.

${ }^{118}$ Por. Jittima Piriyapongsa, Mark T. Rutledge, Sanil Patel, Mark Borodovsky, and I. King JoRdan, „Evaluating the Protein Coding Potential of Exonized Transposable Element Sequences”, Biology Direct 2007, vol. 2, no. 31.

${ }^{119}$ Por. Tracy M. Hall, Jeffery A. Porter, Keith E. Young, Eugene V. Koonin, Philip A. BeACHY, and Daniel J. LeaHY, „Crystal Structure of a Hedgehog Autoprocessing Domain: Homology Between Hedgehog and Self-Splicing Proteins”, Cell 1997, vol. 91, s. 85-97; Thomas R. Bürglin, „Evolution of Hedgehog and Hedgehog-Related Genes, Their Origin from Hog Proteins in Ancestral Eukaryotes and Discovery of a Novel Hint Motif”, BMC Genomics 2008, vol. 9, no. 127.
} 
Wszystkie, bez wyjątku, geny prokariotyczne noszą ślady integracji wielu plazmidów i fagów. Jeszcze wiele więcej mówiące jest to, że genomy archeonów zwykle mają wiele wersji operonu, który koduje kluczowe elementy maszynerii podziału plazmidów, i często wiąże się z nimi więcej niż jedna historia pochodzenia replikacji. ${ }^{120} \mathrm{~W}$ związku $\mathrm{z}$ tym wydaje się, że fuzja różnych replikonów jest stałym zjawiskiem u prokariontów, a w trakcie ewolucji taka fuzja mogła stanowić główny czynnik w kształtowaniu obserwowanej architektury prokariotycznych chromosomów. ${ }^{121}$

Podsumowując, genomika porównawcza i metagenomika ukazują ogromny, dynamiczny, zespolony świat samolubnych replikonów, który wchodzi w interakcje $\mathrm{z}$ genomami komórkowych form życia $\mathrm{i}-\mathrm{w}$ trakcie długich okresów ewolucji - wywiera duży wpływ na skład chromosomów. U prokariontów interakcję między chromosomami bakterii i archeonów a samolubnymi replikonami są tak intensywne, a odrębność chromosomów i megaplazmidów zatarta do tego stopnia, że chromosomy prawdopodobnie najlepiej postrzegać jako „wyspy” względnej stabilności w niespokojnym „morzu” elementów ruchomych. ${ }^{122}$ U eukariontów, szczególnie u form wielokomórkowych, które wykształciły w toku ewolucji rozdział między linią zarodkową a somą, odrębność chromosomów i samolubnych replikonów jest wyraźniejsza. Niemniej wewnątrzgenomowa mobilność samolubnych elementów przestawialnych i międzygenomowa mobilność przynajmniej $\mathrm{w}$ ramach danego gatunku jest $\mathrm{w}$ istocie ułatwiana przez istnienie płci, przy czym serie rozpowszechniania elementów przestawialnych prawdopodobnie zaznaczają ewolucyjne przejścia. ${ }^{123}$ Centralna rola elementów ruchomych w ewolucji genomów podważa też koncepcję drzewa życia,

\footnotetext{
${ }^{120}$ Por. Lakshminarayan M. Iyer, Kira S. Makarova, Eugene V. Koonin, and L. Aravind, „Comparative Genomics of the FtsK-HerA Superfamily of Pumping ATPases: Implications for the Origins of Chromosome Segregation, Cell Division and Viral Capsid Packaging", Nucleic Acids Research 2004, vol. 32, s. 5260-5279.

${ }^{121}$ Por. Koonin and Wolf, „Genomics of Bacteria and Archaea: The Emerging Generalizations After 13 Years...”; Adam T. McGeoch and Stephen D. BelL, „Extra-Chromosomal Elements and the Evolution of Cellular DNA Replication Machineries", Nature Reviews Molecular Cell Biology 2008, vol. 9, s. 569-574.

${ }^{122}$ Por. Koonin and Wolf, „Genomics of Bacteria and Archaea: The Emerging Generalizations After 13 Years...".

${ }^{123}$ Por. Lynch, The Origins of Genome Architecture....
} 
chociaż drzewa filogenetyczne indywidualnych charakterystycznych genów mogą być bardzo przydatne dla rekonstrukcji ewolucji samych samolubnych elementów. ${ }^{124}$

\section{Natura Ostatniego Uniwersalnego Wspólnego Przodka i wczesne przejścia ewolucyjne}

Genomika porównawcza potwierdza domysł Darwina na temat pochodzenia wszystkich istniejących form życia od jednego wspólnego przodka. W rzeczy samej, ewolucyjne rekonstrukcje wskazują, że setki utrwalonych genów najprawdopodobniej wywodzą się od LUCA. ${ }^{125}$ Ściśle rzecz biorąc, rekonstrukcje te dają do zrozumienia, że LUCA posiadał już kompletny system translacji, który nie różnił się diametralnie od (przynajmniej) prostszych wersji współczesnej maszynerii translacyjnej (składającej się z około 100 cząsteczek RNA i białek). Miał również podstawowy system transkrypcji i różne kluczowe szlaki metaboliczne, na przykład dla biosyntezy nukleotydów puryny i pirymidyny. ${ }^{126}$ Zestawom genów przypisywanym w tych rekonstrukcjach LUCA brakuje jednak pewnych istotnych elementów współczesnej maszynerii komórkowej. W szczególności podstawowe składniki maszynerii replikacji DNA są niehomologiczne (lub przynajmniej nieortologowe) u bakterii, z jednej strony, oraz u archeonów i eukariontów, z drugiej. ${ }^{127}$ Istnieje też inny ostry podział: lipidy błonowe mają odmienne struktury, a enzymy biorące udział w biogenezie błon są odpowiednio niehomologiczne (nieortologowe). ${ }^{128}$

\footnotetext{
${ }^{124}$ Por. Yue XIOng and Thomas H. Eickbush, „Origin and Evolution of Retroelements Based Upon Their Reverse Transcriptase Sequences”, EMBO Journal 1990, vol. 9, s. 3353-3362; Eugene V. Koonin, Yuri I. Wolf, Keizo Nagasaki, and Valerian V. Dolja, „The Big Bang of PicornaLike Virus Evolution Antedates the Radiation of Eukaryotic Supergroups", Nature Reviews Microbiology 2008, vol. 6, s. 925-939.

${ }^{125}$ Por. Snel, Bork, and Huynen, „Genomes in Flux...”; Mirkin, Fenner, Galperin, and KooNIN, „Algorithms for Computing Parsimonious Evolutionary Scenarios...”; KoonIN, „Comparative Genomics, Minimal Gene-Sets...”, Kunin and Ouzounis, „The Balance of Driving Forces...”.

${ }^{126}$ Por. Koonin, „Comparative Genomics, Minimal Gene-Sets...”.

${ }^{127}$ Por. Detlef D. Leipe, L. Aravind, and Eugene V. Koonin, „Did DNA Replication Evolve Twice Independently?”, Nucleic Acids Research 1999, vol. 27, s. 3389-3401.

${ }^{128}$ Por. Juli Pereto, Purificacion Lopez-Garcia, and David Moreira, „Ancestral Lipid Biosynthesis and Early Membrane Evolution”, Trends in Biochemical Sciences 2004, vol. 29, s. 469-477.
} 
Duże luki w zrekonstruowanym zestawie genów LUCA stanowią potwierdzenie dla idei, że różne układy komórkowe „skrystalizowały się” asynchronicznie, jak też wskazują na „przejścia fazowe" na wczesnych etapach ewolucji komórkowej. ${ }^{129}$ Zgodnie z jedną klasą hipotez LUCA był skrajnie odmienny od współczesnych komórek, a być może nawet w ogóle nie był komórką, lecz pulą elementów genetycznych stosujących różne strategie replikacji i ekspresji. Mógł ponadto zajmować nieorganiczne obszary, na przykład przy kominach hydrotermalnych. ${ }^{130}$ Zgodnie $\mathrm{z}$ tymi scenariuszami systemy replikacji DNA i błony współczesnego typu wyewoluowały co najmniej dwukrotnie i niezależnie w dwóch domenach życia (zakładając symbiogenetyczne powstanie eukariontów). W tym wypadku samo pojęcie LUCA staje się niejednoznaczne i być może stosowniej mówić o LUCAS - Ostatnim Uniwersalnym Wspólnym Stanie Ancestralnym (Last Universal Common Ancestral State). ${ }^{131}$ Alternatywna klasa scenariuszy postuluje, że LUCA był komórką współczesnego typu, posiadającą archeonową albo bakteryjną odmianę systemów replikacji DNA oraz błony, a może nawet systemy mieszane. ${ }^{132}$ Ta klasa scenariuszy implikuje, że w ewolucji każdego z tych kluczowych układów komórkowych zachodziły zmiany od jednego do drugiego typu lub zróżnicowana utrata poszczególnych genów.

Bez względu na to, który scenariusz jest preferowany, brak utrwalenia centralnych układów komórkowych pośród domen życia wskazuje, że wczesne stadia ewolucji komórki obejmowały radykalne zmiany, które trudno pogodzić $\mathrm{z}$ uniformitarianizmem.

\footnotetext{
${ }^{129}$ Por. Koonin, „The Biological Big Bang Model...”; Carl WoEse, „The Universal Ancestor”, Proceedings of the National Academy of Sciences USA 1998, vol. 95, s. 6854-6859.

${ }^{130}$ Por. William Martin and Michael J. Russell, „On the Origins of Cells: A Hypothesis for the Evolutionary Transitions from Abiotic Geochemistry to Chemoautotrophic Prokaryotes, and from Prokaryotes to Nucleated Cells", Philosophical Transactions of the Royal Society of London B: Biological Sciences 2003, vol. 358, s. 59-83 (dyskusja na s. 83-55); Eugene V. Koonin and William MARTIN, „On the Origin of Genomes and Cells Within Inorganic Compartments”, Trends in Genetics 2005, vol. 21, s. 647-654.

${ }^{131}$ Por. Eugene V. Koonin, „On the Origin of Cells and Viruses: Primordial Virus World Scenario", Annals of the New York Academy of Sciences 2009, vol. 1178, s. 47-64.

${ }^{132}$ Por. Pereto, Lopez-Garcia, and Moreira, „Ancestral Lipid Biosynthesis...”; Nicholas GlansdorfF, Ying Xu, and Bernard Labedan, „The Last Universal Common Ancestor: Emergence, Constitution and Genetic Legacy of an Elusive Forerunner", Biology Direct 2008, vol. 3, no. 29.
} 


\section{Kwantyfikacja selekcji w calych genomach i śmieciowe DNA: odmienne reżimy ewolucyjne dla różnych genomów}

Istnieją duże różnice w składzie genomów między różnymi liniami ewolucji życia. Prokarionty i, zwłaszcza, wirusy mają genomy „od brzegu do brzegu” (wall-to-wall) składające się głównie z genów kodujących białka i strukturalnych RNA, przy czym regiony niekodujące stanowią, poza niewieloma wyjątkami, nie więcej niż 10-15\% genomowego DNA. Genomy eukariontów jednokomórkowych mają mniejszą gęstość charakterystycznych genów, ale na ogół nie odbiegają zbyt daleko od zasad obowiązujących u prokariontów, gdyż pomimo odmiennej egzonowo-intronowej architektury genów, większość DNA koduje białka. Genomy wielokomórkowych eukariontów są radykalnie odmienne pod tym względem, że jedynie mniejszość (niewielka mniejszość u kręgowców) genomowego DNA składa się z sekwencji kodujących białka lub strukturalne RNA. Ogólnie rzecz biorąc, w całym zakresie form życia obserwuje się wyraźną negatywną, wykładniczą zależność między gęstością genów kodujących białka a rozmiarem genomów, chociaż znaczne odchylenia od tej ogólnej zależności obserwowane są również szczególnie u prokariontów (por. rysunek 2).

Ta zasadnicza różnica w organizacji genomów (większości) jednokomórkowych i wielokomórkowych organizmów wymaga wyjaśnienia, a najprostszego wiarygodnego wyjaśnienia dostarcza teoria genetyki populacyjnej, zgodnie z którą intensywność doboru oczyszczającego oddziałującego na populację jest proporcjonalna do rzeczywistego rozmiaru populacji. Utrwalanie sekwencji niekodujących, takich jak introny lub elementy ruchome, jest - w najlepszym wypadku - procesem neutralnym, albo - co bardziej prawdopodobne - nieznacznie szkodliwym, nawet jeśli tylko z powodu dodatkowego obciążenia maszynerii replikacyjnej. Obszerne nagromadzenie takich sekwencji jest więc możliwe jedynie we względnie małych populacjach, w których intensywność doboru oczyszczającego znajduje się poniżej „progu kompleksyfikacji”. Mówiąc dokładniej, teoria przewiduje, że mutacje o współczynniku selekcji $(s)$ mniejszym niż $10^{-6}$ nagromadzałyby się $\mathrm{w}$ genomach wielokomórkowych eukariontów jako mutacje neutralne. Wiele insercji sekwencji niekodujących rzeczywiście związanych jest $\mathrm{z}$ takimi małymi wartościami $s .{ }^{133}$

\footnotetext{
${ }^{133}$ Por. LynCH, The Origins of Genome Architecture...; Michael Lynch and John S. ConERY,
} 


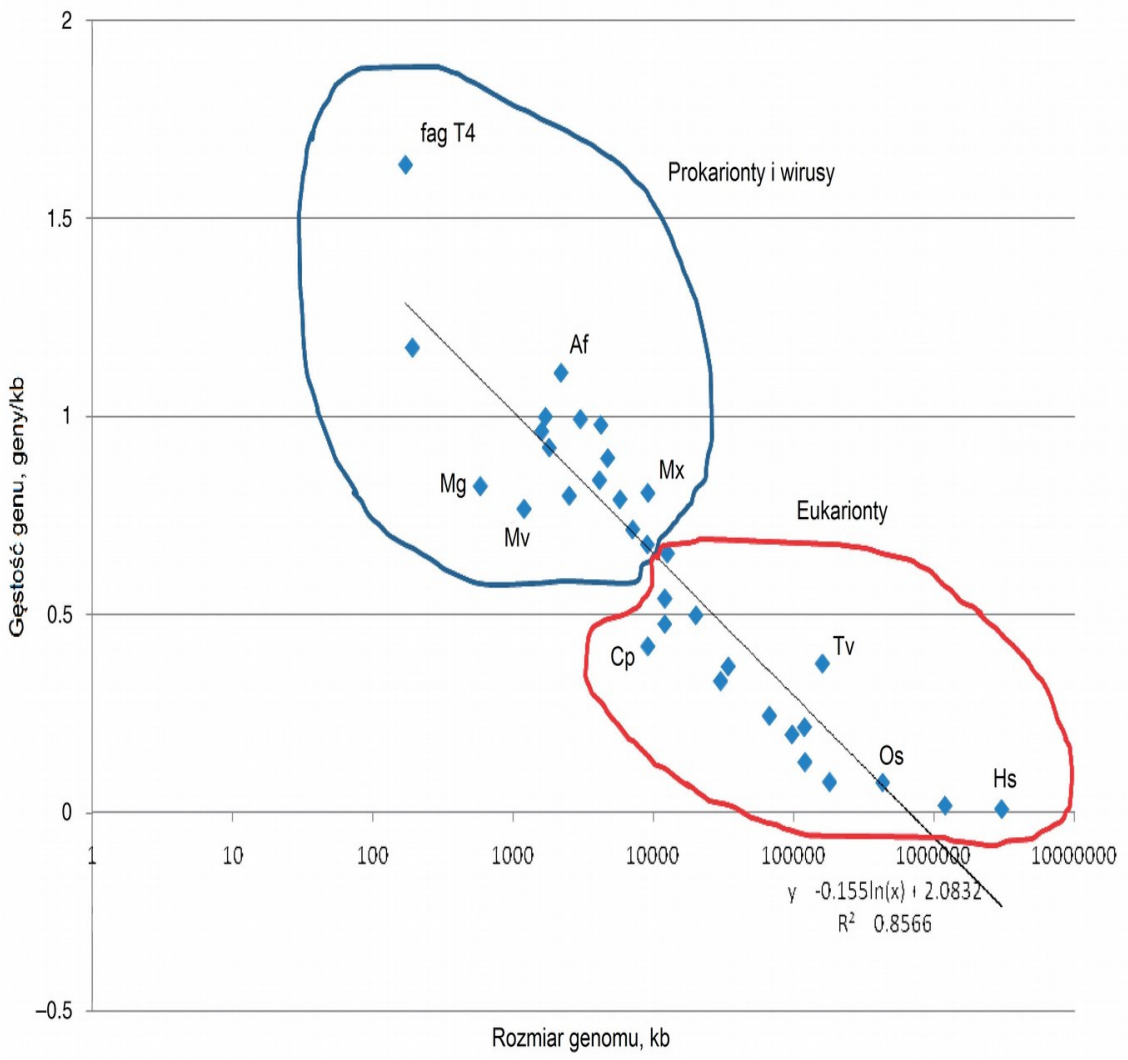

Rys. 2. Zależność między rozmiarem genomów a gęstością genów dla dużych wirusów i różnych komórkowych form życia. Wykres jest semilogarytmiczny. Punkty odpowiadające wybranym organizmom zaznaczono jako: Af, Archaeoglobus fulgidus (archeon); Cp, Cryptosporidium parvum (jednokomórkowy eukariont, Alveolata); Hs, Homo sapiens; Os, Oryza sativa (ryż); Mg, Mycoplasma genitalium (obligatoryjna bakteria pasożytnicza); Mv, mimiwirus; Tv, Trichomonas vaginalis (jednokomórkowy eukariont, Excavata).

Wziąwszy pod uwagę badania nad ewolucją w skali genomu, kolejny ciąg ważnych pytań dotyczy rozkładu współczynników selekcji po genomach: jaka część niekodującego DNA jest naprawdę śmieciowa, jaką presję wywiera dobór

„The Origins of Genome Complexity”, Science 2003, vol. 302, s. 1401-1404; Michael Lynch, "The Frailty of Adaptive Hypotheses for the Origins of Organismal Complexity", Proceedings of the National Academy of Sciences USA 2007, vol. 104, suppl. 1, s. 8597-8604. 
oczyszczający na różne geny i jak często rzeczywiście oddziałuje dobór pozytywny (darwinowski)? Chociaż pomiar doboru dla indywidualnych genów, a tym bardziej dla indywidualnych miejsc, szczególnie w regionach niekodujących, stanowi nie lada wyzwanie techniczne, ${ }^{134}$ pojawiło się kilka analiz dotyczących całych genomów. Szeroko zakrojona analiza ludzkiego zestawu białek, łącząca dane na temat patogenetycznych mutacji, niesynonimicznych SNP i rozbieżności w przypadku ludzkich i szympansich ortologów, umożliwiła obliczenie, że tylko w wypadku $\sim 12 \%$ reszt aminokwasowych $s<10^{-5}$, natomiast blisko połowa miejsc ma wartości między $10^{-4}$ a $10^{-2}$. ${ }^{135}$ Tak więc większość sekwencji białkowych wydaje się podlegać dość silnemu działaniu doboru oczyszczającego. Uzupełniające się $\mathrm{z}$ tą analizą badanie, dotyczące ewolucji reżimów wielu grup blisko spokrewnionych bakterii i archeonów, także ujawniło zazwyczaj silne działanie doboru oczyszczającego. Przy tym odnotowane w całych genomach średnie wartości stosunków $\mathrm{d} N / \mathrm{d} S$ (stosunek tempa substytucji nukleotydów niesynonimicznych względem synonimicznych, który jest tradycyjną miarą selekcji w przypadku sekwencji kodujących białka) wynoszą między 0,02 a $0,2\left(\mathrm{~d} N / \mathrm{d} S<<1\right.$ to sygnatura doboru oczyszczającego). ${ }^{136}$

Zakrojone na całe genomy badania pozytywnego doboru (mierzonego jako specyficzny dla genów stosunek $\mathrm{d} N / \mathrm{d} S$ ) w genach kodujących białka u sześciu gatunków ssaków ujawniły $\sim 400$ genów $(2,5 \%)$, które najwyraźniej doświadczyły doboru pozytywnego w przynajmniej jednej gałęzi drzewa filogenetycznego analizowanych gatunków. Wartości dla większości poszczególnych gałęzi były bardzo małe. ${ }^{137}$ Szacunki te, mimo iż są konserwatywne, pokazują, że przynajmniej u ssaków oddziaływanie doboru pozytywnego na całą sekwencję

\footnotetext{
${ }^{134}$ Por. Martin Kreitman, „Methods to Detect Selection in Populations with Applications to the Human", Annual Review of Genomics and Human Genetics 2000, vol. 1, s. 539-559; Jianzhi Zhang, „Frequent False Detection of Positive Selection by the Likelihood Method with BranchSite Models”, Molecular Biology and Evolution 2004, vol. 21, s. 1332-1339.

${ }^{135}$ Por. Lev Y. Yampolsky, Fyodor A. Kondrashov, and Alexey S. Kondrashov, „Distribution of the Strength of Selection Against Amino Acid Replacements in Human Proteins", Human Molecular Genetics 2005, vol. 14, s. 3191-3201.

${ }^{136}$ Por. Novichrov, Wolf, Dubchak, and Koonin, „Trends in Prokaryotic Evolution...”.

${ }^{137}$ Por. Carolin Kosiol, Tomáš VinaŘ, Rute R. DA FonseCA, Melissa J. Hubisz, Carlos D. Bustamante, Rasmus Nielsen, and Adam Siepel, „Patterns of Positive Selection in Six Mammalian Genomes", PLoS Genetics 2008, vol. 4, e1000144.
} 
genów jest dość rzadkie, chociaż w wielu genach, które na ogół podlegają doborowi oczyszczającemu, prawdopodobnie występują też miejsca powstałe w wyniku działania doboru pozytywnego. Szeroko zakrojone analizy miejsc kodujących aminokwasy ${ }^{*}$ w 12 genomach Drosophila przyniosły bardzo odmienne wyniki, co wskazuje, że znaczna część, a być może większość substytucji aminokwasów podlega doborowi pozytywnemu, aczkolwiek korzystne skutki większości tych substytucji wydają się dość niewielkie. ${ }^{138}$ Zwłaszcza rozkład miejsc podlegających doborowi pozytywnemu jest silnie nielosowy pośród funkcjonalnych kategorii genów, zaś szczególnie wrażliwe na działanie doboru pozytywnego są geny związane $\mathrm{z}$ odpornością i innymi funkcjami obronnymi, reprodukcją oraz percepcją zmysłową. Wygląda na to, że rozkład ten był stabilny u bardzo odmiennych zwierząt, $w$ tym u ssaków, much i nicieni. ${ }^{139}$

Palącą kwestią w badaniach ewolucyjnych nacelowanych na całe genomy, zwłaszcza jeśli chodzi o ssaki z ich ogromnymi genomami, jest to, jaka część niekodującego DNA jest „naprawdę” śmieciowa i jaka jego część podlega jeszcze nieznanym wymogom funkcjonalnym. Możliwość, że pomimo braku wykrywalnego utrwalenia ewolucyjnego duża część, o ile nie większość, ludzkiego DNA ma $\mathrm{w}$ istocie znaczenie funkcjonalne $\mathrm{i}$ tym samym podlega doborowi, jest często dyskutowana, zwłaszcza w świetle wyników pokazujących, że bardzo duża część genomu ulega transkrypcji. ${ }^{140}$ Odkrycie, że tak zwane ultrakonser-

\footnotetext{
* (Przyp. thum.) Miejsca kodujące aminokwasy — skrót myślowy Autora, dotyczący sekwencji w obrębie badanych genów odpowiadających poszczególnym aminokwasom w polipeptydach kodowanych przez te geny.

${ }^{138}$ Por. Andrew G. Clark, Michael B. Eisen, Douglas R. Smith, Casey M. Bergman, Brian Oliver, Therese A. Markow, Thomas C. Kaufman, Manolis Kellis, William Gelbart, Venky N. Iyer et al., „Evolution of Genes and Genomes on the Drosophila Phylogeny”, Nature 2007, vol. 450, s. 203-218; Stanley A. Sawyer, John Parsch, Zhi Zhang, and Daniel L. Hartl, „Prevalence of Positive Selection Among Nearly Neutral Amino Acid Replacements in Drosophila", Proceedings of the National Academy of Sciences USA 2007, vol. 104, s. 6504-6510.

${ }^{139}$ Por. Kosiol, Vinař, da Fonseca, Hubisz, Bustamante, Nielsen, and Siepel, „Patterns of Positive Selection...”; Clark, Eisen, Smith, Bergman, Oliver, Markow, Kaufman, Kellis, Gelbart, Iyer et al., „Evolution of Genes...”; Cristian I. Castillo-Davis, Fyodor A. Kondrashov, Daniel L. HartL, and Rob J. Kulathinal, „The Functional Genomic Distribution of Protein Divergence in Two Animal Phyla: Coevolution, Genomic Conflict, and Constraint”, Genome Research 2004, vol. 14, s. 802-811.

${ }^{140}$ Por. Emile ZuckerkandL, „Why So Many Noncoding Nucleotides?: The Eukaryote Genome as an Epigenetic Machine", Genetica 2002, vol. 115, s. 105-129; Michael PHEASANT and
} 
watywne sekwencje, które wydają się podlegać niezwykle silnemu doborowi oczyszczającemu, ${ }^{141}$ jest zgodne z tą ideą. Ponadto znaczna część „śmieciowego" DNA może być zaangażowana w funkcjonalne role, które pociągają za sobą tylko ograniczone utrwalanie sekwencji, ale są ważne szczególnie dla utrzymywania i reorganizowania struktury chromatyny, jak w przypadku regionów przyłączeniowych pełniących funkcję rusztowania/matrycy (SAR/MAR). ${ }^{142} \mathrm{Nie}-$ mniej niedawno przeprowadzona, dotycząca całych genomów analiza rozkładu insercji i delecji (porównanie genomów człowieka, myszy i psa) wskazuje, że tylko $\sim 3 \%$ ludzkiej euchromatyny DNA podlega wymogom selekcyjnym. ${ }^{143}$ Zważywszy na to, że sekwencje kodujące białka stanowią jedynie $\sim 1,2 \%$ euchromatyny, wyniki te wskazują, że większość sekwencji DNA o znaczeniu funkcjonalnym u ssaków nie koduje białek, lecz potwierdzają też wczesne przypuszczenia, iż większa część ludzkiego genomu jest niefunkcjonalna, czyli mimo wszystko śmieciowa. ${ }^{144}$ Oczywiście należy pamiętać o tym, że każda definicja tego, co śmieciowe, jest warunkowa, to znaczy niegdysiejsze śmieci jutro mogą zostać zwerbowane do pełnienia funkcjonalnej roli. Natomiast międzygatunkowe porównania niekodujących regionów genomowych u Drosophila wskazują, że większość (70\% lub więcej nukleotydów) tych sekwencji wyewoluowała, podlegając wymogom selekcyjnym, a znaczna część (do 20\%) najwy-

John S. Matтick, „Raising the Estimate of Functional Human Sequences”, Genome Research 2007, vol. 17, s. 1245-1253; Paulo P. Amaral, Marcel Dinger, Tim R. Mercer, and John S. MatTICK, „The Eukaryotic Genome as an RNA Machine”, Science 2008, vol. 319, s. 1787-1789.

${ }^{141}$ Por. Gill Bejerano, Michael Pheasant, Igor Makunin, Stuart Stephen, W. James Kent, John S. Mattick, and David Haussler, „Ultraconserved Elements in the Human Genome”, Science 2004, vol. 304, s. 1321-1325; Sol Katzman, Andrew D. Kern, Gill Bejerano, Ginger Fewell, Lucinda Fulton, Richard K. Wilson, Sofie R. Salama, and David Haussler, „Human Genome Ultraconserved Elements Are Ultraselected", Science 2007, vol. 317, s. 915.

${ }^{142}$ Por. Galina V. Glazko, Eugene V. Koonin, Igor B. Rogozin, and Svetlana A. Shabalina, „A Significant Fraction of Conserved Noncoding DNA in Human and Mouse Consists of Predicted Matrix Attachment Regions", Trends in Genetics 2003, vol. 19, s. 119-124; Amelia K. LiNnemann, Adrian E. Platts, and Stephen A. Krawetz, „Differential Nuclear Scaffold/Matrix Attachment Marks Expressed Genes", Human Molecular Genetics 2009, vol. 18, s. 645-654.

${ }^{143}$ Por. Gerton Lunter, Chris P. Ponting, and Jotun Hein, „Genome-Wide Identification of Human Functional DNA Using a Neutral Indel Model”, PLoS Computational Biology 2006, vol. 2 , e5.

${ }^{144}$ Por. Doolittle and SAPIEnZA, „Selfish Genes...”; Orgel and Crick, „Selfish DNA...”. 
raźniej podlega wpływowi doboru pozytywnego. ${ }^{145}$ Bez wątpienia badania te opierają się na różnych upraszczających założeniach (których nie mogę tu szczegółowo omówić), tak więc do wniosku o dużych różnicach w reżimach selekcyjnych między różnymi liniami rodowymi należy podchodzić z ostrożnością i trzeba poddać go dalszej weryfikacji. Niemniej sam fakt, że organizmy o porównywalnych rozmiarach zestawów genów i poziomach złożoności organizacyjnej, takie jak owady, z jednej strony, i ssaki, z drugiej, tak radykalnie różnią się gęstością genów i ilością domniemanych genomowych „śmieci” (por. rysunek 2), wskazuje, że ich genomy ewoluują, podlegając różnym naciskom selekcyjnym.

Badania wzajemnej zależności procesów neutralnych, doboru oczyszczającego i doboru pozytywnego wciąż znajdują się na wczesnym etapie. Zbiór zestawów blisko spokrewnionych genomów z różnych taksonów, który ma istotne znaczenie dla tej analizy, jest obecnie mały, chociaż szybko się powiększa, a metody odróżniania różnych trybów ewolucji ciągle są aktywnie opracowywane. Niemniej nawet dostępne już wyniki zupełnie jasno wskazują, że wkład każdego z tych czynników jest wysoce zmienny pośród organizmów, w zależności od rzeczywistego rozmiaru populacji, charakterystycznego tempa mutacji i rekombinacji, a całkiem prawdopodobne, że nie odkryto jeszcze wkładu innych czynników.

\section{Duplikacja genów i genomów: glówna ścieżka genomowej innowacji}

Analiza licznych sekwencji genomów potwierdziła wysnutą przez Ohno wizję duplikacji genów jako głównego mechanizmu ewolucji, ${ }^{146}$ być może nawet w większym stopniu niż przewidywał twórca tej koncepcji. Większa część genów w większości genomów komórkowych form życia (z wyjątkiem najmniejszych genomów obligatoryjnych pasożytów) posiada paralogi wskazujące na to,

\footnotetext{
${ }^{145}$ Por. Peter Andolfatto, „Adaptive Evolution of Non-Coding DNA in Drosophila”, Nature 2005, vol. 437, s. 1149-1152; Daniel L. Halligan and Peter D. Keightley, „Ubiquitous Selective Constraints in the Drosophila Genome Revealed by a Genome-Wide Interspecies Comparison”, Genome Research 2006, vol. 16, s. 875-884; Penelope R. Haddrill, Doris Bachtrog, and Peter Andolfatto, „Positive and Negative Selection on Noncoding DNA in Drosophila simulans”, Molecular Biology and Evolution 2008, vol. 25, s. 1825-1834.

${ }^{146}$ Por. Ohno, Evolution by Gene Duplication....
} 
że w pewnym momencie ewolucji nastąpiła duplikacja, ${ }^{147}$ a wiele genów należy do dużych rodzin paralogów, z którymi wiąże się charakterystyczny rozkład wykładniczy odnośnie do liczby ich członków. ${ }^{148}$ Jeśli chodzi o wkład duplikacji w powstawanie nowych genów, należy zauważyć, że dysponujemy niewieloma świadectwami powstania genów de novo z sekwencji niekodujących, chociaż geny mogą się rozrastać dzięki werbowaniu małych, przyległych odcinków niekodujących sekwencji. ${ }^{149}$ Kusząca jest więc generalizacja, zgodnie z którą duplikacja genów jest nie tylko ważną, ale i dominującą ścieżką powstawania nowych genów. Należy jednak dodać, że po duplikacji często następuje przyspieszona ewolucja sekwencji, jak również przemodelowanie genu - jest to tryb ewolucji zacierający wykrywalne związki z pierwotnym źródłem.

Idea Ohno na temat eliminacji lub osłabienia doboru po duplikacji genu, dopuszczająca ewolucję mogącą tworzyć funkcjonalne nowości, również została potwierdzona przez dane genomiki porównawczej, chociaż towarzyszył temu ważny zwrot wypadków. Argumentowano na poziomie teoretycznym, a następnie wykazano drogą empirycznych pomiarów presji selekcyjnej wywieranej na niedawno zduplikowane sekwencje genów, że osłabienie doboru oczyszczającego było najprawdopodobniej symetryczne i wpływało na obie kopie w mniej lub bardziej równym stopniu. ${ }^{150}$ Tak więc powszechniejszą ścieżką ewolucji zduplikowanych genów może nie być neofunkcjonalizacja postulowana przez Ohno,

\footnotetext{
${ }^{147}$ Por. Lynch, The Origins of Genome Architecture...; Koonin, Mushegian, and Rudd, „Sequencing and Analysis...".

${ }^{148}$ Por. Martijn A. Huynen and Erik van Nimwegen, „The Frequency Distribution of Gene Family Sizes in Complete Genomes", Molecular Biology and Evolution 1998, vol. 15, s. 583-589; Georgy P. Karev, Yuri I. Wolf, Andrey Y. Rzhetsky, Faina S. Berezovskaya, and Eugene V. KooNIN, „Birth and Death of Protein Domains: A Simple Model of Evolution Explains Power Law Behavior", BMC Evolutionary Biology 2002, vol. 2, no. 18. Por. też poniższe omówienie.

${ }^{149} \mathrm{Na}$ przykład z intronu (por. Fyodor A. Kondrashov and Eugene V. Koonin, „Evolution of Alternative Splicing: Deletions, Insertions and Origin of Functional Parts of Proteins from Intron Sequences", Trends in Genetics 2003, vol. 19, s. 115-119). Powstanie zupełnie nowego genu tą drogą wydaje się zjawiskiem wyjątkowym (por. Manyuan Long, Esther BEtRán, Kevin Thornton, and Wen WANG, ,The Origin of New Genes: Glimpses from the Young and Old”, Nature Reviews Genetics 2003, vol. 4, s. 865-875).

${ }^{150}$ Por. Michael Lynch and John S. Conery, „The Evolutionary Fate and Consequences of Duplicate Genes”, Science 2000, vol. 290, s. 1151-1155; Fyodor A. KondRashov, Igor B. Rogozin, Yuri I. Wolf, and Eugene V. Koonin, „Selection in the Evolution of Gene Duplications”, Genome Biology 2002, vol. 3, RESEARCH0008.
} 
lecz subfunkcjonalizacja, w której nowej paralogi zachowują odrębne podzbiory pierwotnych funkcji genu ancestralnego, podczas gdy reszta funkcji degeneruje się w sposób zróżnicowany. ${ }^{151}$ Bardziej wyrafinowane analizy zdają się wskazywać, że oba reżimy ewolucji mogą zachodzić na różnych stadiach historii genów paralogowych, przy czym szybka subfunkcjonalizacja zachodząca bezpośrednio po duplikacji następowała po dalszej, wolniejszej neofunkcjonalizacji. ${ }^{152}$

Duplikacja genów następuje przez cały okres ewolucji każdej linii rodowej, ale tempo duplikacji nie jest jednakowe w dużych skalach ewolucyjnych. Przejściom organizacyjnym w ewolucji zdają się więc towarzyszyć eksplozje duplikacji genów, umożliwione, jak można przypuszczać, przez słaby dobór oczyszczający podczas następowania populacyjnych wąskich gardeł (por. niżej). Być może najlepiej ilustruje to powstanie eukariontów, któremu towarzyszyła masowa fala duplikacji, co utworzyło charakterystyczny, wielo-jednoznaczny, współortologowy związek między genami eukariontów a ich prokariotycznymi przodkami. ${ }^{153}$ Podobnie sądzi się, że zróżnicowana duplikacja grup genów Hox i innych regulatorów rozwoju odgrywała decydującą rolę w procesie różnicowania się typów zwierząt. ${ }^{154}$ Możliwe, że najdramatyczniejsze przypadki „saltacyjnej” duplikacji genów obejmowały duplikację całych genomów (WGD - whole-

${ }^{151}$ Por. Michael Lynch and Allan Force, ,The Probability of Duplicate Gene Preservation by Subfunctionalization", Genetics 2000, vol. 154, s. 459-473; Michael LyNCH and Vaishali Katsu, „The Altered Evolutionary Trajectories of Gene Duplicates”, Trends in Genetics 2004, vol. 20, s. 544-549.

${ }^{152}$ Por. Xionglei He and Jianzhi ZHANG, „Rapid Subfunctionalization Accompanied by Prolonged and Substantial Neofunctionalization in Duplicate Gene Evolution”, Genetics 2005, vol. 169, s. 1157-1164; Devin R. Scannell and Kenneth H. Wolfe, „A Burst of Protein Sequence Evolution and a Prolonged Period of Asymmetric Evolution Follow Gene Duplication in Yeast", Genome Research 2008, vol. 18, s. 137-147; Gavin C. Conant and Kenneth H. Wolfe, „Turning a Hobby into a Job: How Duplicated Genes Find New Functions", Nature Reviews Genetics 2008, vol. 9, s. 938-950.

${ }^{153}$ Por. Kira S. Makarova, Yuri I. Wolf, Sergey L. Mekhedov, Boris G. Mirkin, and Eugene V. Koonin, „Ancestral Paralogs and Pseudoparalogs and Their Role in the Emergence of the Eukaryotic Cell”, Nucleic Acids Research 2005, vol. 33, s. 4626-4638.

${ }^{154}$ Por. Simone Hoegg and Axel Meyer, „Hox Clusters as Models for Vertebrate Genome Evolution”, Trends in Genetics 2005, vol. 21, s. 421-424; Gunte P. WaGner, Chris AmEmiYa, and Frank Ruddle, „Hox Cluster Duplications and the Opportunity for Evolutionary Novelties”, Proceedings of the National Academy of Sciences USA 2003, vol. 100, s. 14603-14606. 
genome duplication). ${ }^{155}$ Podążając za pierwotną hipotezą Ohno, analiza genomów wykazała ślady niezależnej WGD zachowane w rozkładzie rozmiarów rodzin genów paralogowych lub pozycji paralogowych regionów w genomie, pomimo rozległej utraty genów po WGD u drożdży, ${ }^{156}$ strunowców ${ }^{157}$ i roślin. ${ }^{158}$ Pod względem mechanicznym duża przewaga WGD u eukariontów może nie być szczególnie zaskakująca, ponieważ jest skutkiem dobrze znanego, powszechnego zjawiska genetycznego - poliploidyzacji. Ewolucyjne konsekwencje WGD okazują się jednak doniosłe, gdyż zdarzenia te stwarzają możliwość jednoczesnej szybkiej sub/neofunkcjonalizacji w całym zestawie genów organizmu. ${ }^{159} \mathrm{~W}$ szczególności uważa się, że grało kluczową rolę w początkowej radiacji strunowców. ${ }^{160}$ Trudno wykluczyć możliwość, że bardziej niedawne WGD nie są już łatwo wykrywalne ze względu na liczne utraty genów, które zagłuszają sygnał WGD. Zwłaszcza eksplozje duplikacji, które nastąpiły po eukariogenezie, lecz poprzedzają ostatniego wspólnego przodka istniejących obecnie

\footnotetext{
${ }^{155}$ Por. Michael Freeling, „The Evolutionary Position of Subfunctionalization, Downgraded”, Genome Dynamics 2008, vol. 4, s. 25-40.

${ }^{156}$ Por. Devin R. Scannell, Geraldine Butler, and Kenneth H. Wolfe, „Yeast Genome Evolution - The Origin of the Species”, Yeast 2007, vol. 24, s. 929-942; Kenneth H. Wolfe and Denis C. ShiELDS, „Molecular Evidence for an Ancient Duplication of the Entire Yeast Genome”, Nature 1997, vol. 387, s. 708-713.

${ }^{157}$ Por. Paramvir Dehal and Jeffrey L. Boore, „Two Rounds of Whole Genome Duplication in the Ancestral Vertebrate”, PLoS Biology 2005, vol. 3, e314; Dannie Durand, „Vertebrate Evolution: Doubling and Shuffling with a Full Deck", Trends in Genetics 2003, vol. 19, s. 2-5; Aoife McLysaght, Karsten Hokamp, and Kenneth H. Wolfe, „Extensive Genomic Duplication During Early Chordate Evolution", Nature Genetics 2002, vol. 31, s. 200-204; Georgia Panopoulou, Steffen Hennig, Detlef Groth, Antje Krause, Albert J. Poustra, Ralf Herwig, Martin Vingron, and Hans Lehrach, „New Evidence for Genome-Wide Duplications at the Origin of Vertebrates Using an Amphioxus Gene Set and Completed Animal Genomes", Genome Research 2003, vol. 13, s. 1056-1066.

${ }^{158}$ Por. Douglas E. Soltis, Charles D. Bell, Sangtae Kim, and Pamela S. Soltis, „Origin and Early Evolution of Angiosperms", Annals of the New York Academy of Sciences 2008, vol. 1133, s. 3-25; Gerald A. Tuskan, Stephen Difazio, Stefan Jansson, J. Bohlmann, Igor Grigoriev, Uffe Hellsten, Nicholas Putnam, S. Ralph, Stephane Rombauts, Asaf Salamov et al., „The Genome of Black Cottonwood, Populus trichocarpa (Torr. \& Gray)", Science 2006, vol. 313, s. 1596-1604.

${ }^{159}$ Por. Marie SÉmon and Kenneth H. Wolfe, „Consequences of Genome Duplication”, Current Opinion in Genetics and Development 2007, vol. 17, s. 505-512.

${ }^{160}$ Por. Dehal and Boore, „Two Rounds of Whole Genome Duplication...”.
} 
eukariontów, mogły być skutkiem pierwszej WGD w ewolucji eukariontów. ${ }^{161}$

Zważywszy na szerokie występowanie WGD w wielu liniach rodowych eukariontów, warto zauważyć, że jak dotąd żadnych takich zdarzeń nie wykryto w ramach analizy licznych dostępnych genomów prokariontów, chociaż wielokrotnie obserwowano przejściową poliploidalność. ${ }^{162}$ Jak można przypuszczać, brak wykrywalnej WGD u prokariontów ma związek ze skutecznym doborem oczyszczającym, który działa w dużych populacjach prokariontów (por. niżej) i prowadzi do szybkiej eliminacji zduplikowanych genów, która zatarłaby ślady WGD, gdyby takie zdarzenie nastąpiło.

Na poziomie ogólnych koncepcji biologii ewolucyjnej, które mam tu głównie na myśli, genomowe badania nad duplikacją genów prowadzą co najmniej do dwóch istotnych uogólnień. Po pierwsze, wykazanie zasadniczego ewolucyjnego znaczenia duplikacji, wliczając $w$ to duplikacje dużych regionów genomów i całych genomów, to właściwie gwóźdź do trumny gradualizmu darwinowskiego: nawet pojedynczą duplikację genu trudno uznać za nieskończenie małą zmianę, natomiast WGD kwalifikuje się jako prawdziwe zdarzenie saltacyjne. Po drugie, nadrzędność duplikacji genu, w połączeniu z dalszą (niekiedy szybką) dywersyfikacją paralogów jako drogą powstawania nowych genów, wzmacnia metaforę ewolucji jako majsterkowicza: ewolucja wyraźnie przejawia tendencję do tworzenia nowych funkcjonalnych mechanizmów, majstrując przy starych mechanizmach po wykonaniu kopii zapasowej, nie zaś tworząc nowości od zera.

\section{Powstawanie i ewolucja zlożoności genomów: paradygmat nieselekcjonistyczny i błędność idei postępu ewolucyjnego}

Bez wątpienia wielokomórkowe eukarionty, takie jak zwierzęta i rośliny, cechuje znacznie większa złożoność organizacyjna niż jednokomórkowe formy

\footnotetext{
${ }^{161}$ Por. Makarova, Wolf, Mekhedov, Mirkin, and Koonin, „Ancestral Paralogs and Pseudoparalogs...".

${ }^{162}$ Por. Jennifer E. Mendell, Kendall D. Clements, J. Howard Choat, and Esther R. Angert, „Extreme Polyploidy in a Large Bacterium”, Proceedings of the National Academy of Sciences USA 2008, vol. 105, s. 6730-6734; Deborah M. Tobiason and H. Steven SeIFert, „The Obligate Human Pathogen, Neisseria gonorrhoeae, Is Polyploid”, PLoS Biology 2006, vol. 4, e185.
} 
życia. W duchu Nowoczesnej Syntezy złożoność tę postrzega się na ogół jako skutek licznych zmian przystosowawczych napędzanych przez dobór naturalny, a tym samym można ją uznawać za przejaw ,postępu” w ewolucji. Korespondencja między złożonością organizacyjną a złożonością genomową nie jest łatwa do zdefiniowania. Prosta i możliwa do przyjęcia definicja może skupiać się na liczbie nukleotydów przenoszących funkcjonalną informację, to jest na które oddziałuje dobór. ${ }^{163} \mathrm{~W}$ świetle tej definicji genomy wielokomórkowych eukariontów są oczywiście znacznie bardziej złożone od genomów form jednokomórkowych, a większa złożoność genomowa przekłada się też na złożoność funkcjonalną.

Dobitnym tego przykładem jest alternatywny splicing, to jest kluczowy funkcjonalny mechanizm w złożonych organizmach, takich jak ssaki, u których tworzy kilkakrotnie więcej białek niż jest genów kodujących białka ${ }^{164}$ (tak więc faktu, że ludzie mają $\sim 20000$ genów w porównaniu z $\sim 10000$ genów u bakterii Myxococcus xanthus, nie należy przekładać na twierdzenie, że „ludzki proteom jest dwukrotnie bardziej złożony od proteomu bakterii”: prawdziwa różnica więcej zawdzięcza alternatywnemu splicingowi). Alternatywny splicing jest możliwy dzięki słabym sygnałom splicingowym, które są przetwarzane lub pomijane przez spliceosom z porównywalnymi częstościami. ${ }^{165} \mathrm{~W}$ pewnym sensie mające funkcjonalne znaczenie przypadki alternatywnego splicingu są zakodowane w tych łączach splicingowych i do pewnego stopnia w dodatkowych sekwencjach intronów. Czy jednak alternatywny splicing wyewoluował jako funkcjonalna adaptacja? $\mathrm{Z}$ całym prawdopodobieństwem - nie. $\mathrm{W}$ istocie wykazano, że genomy bogate $\mathrm{w}$ introny zwykle mają słabe sygnały splicingowe, podczas gdy genomy mające mało intronów (przeważnie genomy jednokomórkowych

\footnotetext{
${ }^{163}$ Por. Christoph Adami, „What is Complexity?”, BioEssays 2002, vol. 24, s. 1085-1094; Eugene V. Koonin, „A Non-Adaptationist Perspective on Evolution of Genomic Complexity Or the Continued Dethroning of Man”, Cell Cycle 2004, vol. 3, s. 280-285.

${ }^{164}$ Por. Rotem Sorek, Ron Shamir, and Gil Ast, „How Prevalent Is Functional Alternative Splicing in the Human Genome?", Trends in Genetics 2004, vol. 20, s. 68-71; Irena I. ArtamoNOva and Mikhail S. Gelfand, „Comparative Genomics and Evolution of Alternative Splicing: The Pessimists' Science”, Chemical Review 2007, vol. 107, s. 3407-3430; Jung Woo PARK and Brenton R. Graveley, „Complex Alternative Splicing”, Advances in Experimental Medicine and Biology 2007, vol. 623, s. 50-63.

${ }^{165}$ Por. Douglas L. Black, „Mechanisms of Alternative Pre-Messenger RNA Splicing”, Annual Review of Biochemistry 2003, vol. 72, s. 291-336.
} 
eukariontów) mają sztywne łącza splicingowe, które przypuszczalnie zapewniają wysoką wierność splicingu. ${ }^{166}$ Niedawno przeprowadzone, szczegółowe badania wykazały niską precyzję splicingu u organizmów bogatych w introny, przez co powstają liczne warianty będące rezultatem błędnego splicingu, które w większości są niszczone za pośrednictwem wykrywającego nonsensowność systemu rozpadu (NMD - nonsense-mediated decay). ${ }^{167}$ Ewolucyjne rekonstrukcje stanowczo wskazują, że pradawne eukarionty, w tym ostatni wspólny przodek istniejących dziś form, miały duże gęstości intronów porównywalne ze współczesnymi genomami bogatymi w introny, takimi jak u kręgowców, ${ }^{168} \mathrm{i}-$ w konsekwencji - miały słabe sygnały splicingowe przynoszące liczne alternatywne transkrypty. ${ }^{169}$ Utrwalenie maszynerii NMD u wszystkich eukariontów ${ }^{170}$ w pełni wpisuje się w ramy tej hipotezy. Wydaje się więc, że alternatywny splicing pojawił się jako ,genomowy defekt”, którego omawiane organizmy nie mogły się pozbyć, przypuszczalnie z powodu działania doboru oczyszczającego, i wykształciły one specjalny mechanizm, który potrafił sobie z tym poradzić, mianowicie NMD. Stopniowo wykształciły także sposoby używania tego „naroża łuku" do pełnienia wielu funkcji.

Powyższe ujęcie pochodzenia alternatywnego splicingu może stanowić wyraz nieadaptacjonistycznej, populacyjno-genetycznej teorii ewolucji złożoności

\footnotetext{
${ }^{166}$ Por. Manuel Irimia, David Penny, and Scott W. Roy, „Coevolution of Genomic Intron Number and Splice Sites”, Trends in Genetics 2007, vol. 23, s. 321-325.

${ }^{167}$ Por. Olivier Jaillon, Khaled Bounouche, Jean-François Gout, Jean-Marc Aury, Benjamin Noel, Baptiste Saudemont, Mariusz Nowacki, Vincent Serrano, Betina M. Porcel, Béatrice SÉGURENS et al., „Translational Control of Intron Splicing in Eukaryotes”, Nature 2008, vol. 451, s. 359-362.

${ }^{168}$ Por. Scott W. Roy, „Intron-Rich Ancestors”, Trends in Genetics 2006, vol. 22, s. 468-471; Liran Carmel, Yuri I. Wolf, Igor B. Rogozin, and Eugene V. Koonin, „Three Distinct Modes of Intron Dynamics in the Evolution of Eukaryotes", Genome Research 2007, vol. 17, s. 1034-1044; Miklós CsüRös, Igor B. Rogozin, and Eugene V. Koonin, „Extremely Intron-Rich Genes in the Alveolate Ancestors Inferred with a Flexible Maximum-Likelihood Approach", Molecular Biology and Evolution 2008, vol. 25, s. 903-911.

${ }^{169}$ Por. Irimia, Penny, and Roy, „Coevolution of Genomic Intron...”.

${ }^{170}$ Por. Michael Lynch and Avinash Kewalramani, „Messenger RNA Surveillance and the Evolutionary Proliferation of Introns”, Molecular Biology and Evolution 2003, vol. 20, s. 563 571.
} 
genomowej, którą przedstawił niedawno Michael Lynch. ${ }^{171} \mathrm{~W}$ poprzedniej części poczyniłem już aluzję do tego, że główną zasadą tej teorii jest teza, iż zmiany genetyczne prowadzące do wzrostu złożoności, takie jak duplikacje genów lub insercje intronów, są nieznacznie szkodliwe i dlatego mogą zostać utrwalone w dość szybkim tempie tylko wówczas, gdy dobór oczyszczający w populacji jest słaby. Zatem, zważywszy na to, że siła doboru oczyszczającego jest proporcjonalna do rzeczywistego rozmiaru populacji, znaczny wzrost złożoności genomowej jest możliwy jedynie podczas populacyjnych wąskich gardeł. Zgodnie $\mathrm{z}$ tą koncepcją złożoność genomowa nie jest pierwotnie przystosowawcza, lecz powstaje za sprawą neutralnych procesów ewolucyjnych, gdy dobór oczyszczający nie jest skuteczny. Innymi słowy, punktem wyjścia kompleksyfikacji jest „genomowy syndrom”, chociaż złożone cechy („naroża łuków”) są następnie werbowane do pełnienia różnych funkcji i zaczynają podlegać działaniu doboru. Natomiast w odnoszących sukcesy, dużych populacjach, jak w przypadku wielu prokariontów, dobór oczyszczający jest tak intensywny, że żaden wzrost złożoności genomowej nie jest realny i bardziej prawdopodobne jest kurczenie się genomu.

Oczywiście istnieją wyjątki od tych zasad, na przykład genomy bakterii liczące ponad 12000 genów, ${ }^{172}$ genomy wirusów z mocno namnożonymi zduplikowanymi genami ${ }^{173}$ oraz genomy jednokomórkowych eukariontów (na przykład Chlamydomonas ${ }^{174}$ lub Trichomonas ${ }^{175}$ ), które — wedle większości kryte-

\footnotetext{
${ }^{171}$ Por. LynCH, The Origins of Genome Architecture...; LynCH and ConERY, „The Origins of Genome Complexity...”; LyNCH, „The Frailty of Adaptive Hypotheses...”.

${ }^{172}$ Por. Susanne Schneiker, Olena Perlova, Olaf Kaiser, Klaus Gerth, Aysel Alici, Matthias O. Altmeyer, Daniela Bartels, Thomas Bekel, Stefan Beyer, Edna Bode et al., „Complete Genome Sequence of the Myxobacterium Sorangium cellulosum", Nature Biotechnolology 2007, vol. 25, s. 1281-1289.

${ }^{173}$ Por. Iyer, BalaJ, Koonin, and Aravind, „Evolutionary Genomics...”.

${ }^{174}$ Por. Sabeeha S. Merchant, Simon E. Prochnik, Olivier Vallon, Elizabeth H. Harris, Steven J. Karpowicz, George B. Witman, Astrid Terry, Asaf Salamov, Lilian K. Fritz-Laylin, Laurence Maréchal-Drouard et al., „The Chlamydomonas Genome Reveals the Evolution of Key Animal and Plant Functions", Science 2007, vol. 318, s. 245-250.

${ }^{175}$ Por. Jane M. Carlton, Robert P. Hirt, Joana C. Silva, Arthur L. Delcher, Michael Schatz, Qi Zhao, Jennifer R. Wortman, Shelby L. Bidwell, U. Cecilia M. Alsmark, Sébastien Besteiro et al., „Draft Genome Sequence of the Sexually Transmitted Pathogen Trichomonas vaginalis", Science 2007, vol. 315, s. 207-212.
} 
riów - są równie złożone, jak genomy wielokomórkowych zwierząt lub roślin. Ponadto niektóre genomy prokariontów (na przykład Sulfolobus solfataricus należącego do Crenarchaeota ${ }^{176}$ ) i genomy jednokomórkowych eukariontów (na przykład Trichomonas vaginalis ${ }^{177}$ ) są jednymi z posiadających najwyższą zawartość elementów przestawialnych. Najwyraźniej wynik ewolucji genomów zależy od równowagi między presją doboru oczyszczającego, który sam jest zależny od rozmiaru populacji, tempa mutacji, intensywności procesów rekombinacyjnych i aktywności elementów samolubnych, a adaptacją do szczególnych siedlisk. ${ }^{178}$ Pewna atrakcyjna hipoteza głosi, że — przynajmniej u prokariontów — górna granica liczby genów w genomie (dobry zastępnik złożoności genomowej) determinowana jest przez „koszty regulacyjne (biurokratyczne)”. ${ }^{179}$ Istnienie takich kosztów jest sugerowane przez godną uwagi obserwację, że różne funkcjonalne klasy genów mają różne skalowania ze względu na całkowitą liczbę genów w genomie. Zwłaszcza geny regulatorowe (takie jak represory i aktywatory transkrypcji) wykazują (niemal) skalowanie do drugiej potęgi. ${ }^{180}$ Jak można przypuszczać, przy pewnym stosunku liczby regulatorów do liczby regulowanych genów, być może bliskim 1:1, obciążenie regulatorów staje się nie do utrzymania. Tak więc ewolucja złożoności genomowej niewątpliwie zależna jest od złożonej kombinacji procesów stochastycznych (neutralnych) i adaptacyj-

\footnotetext{
${ }^{176}$ Por. Qunxin She, Rama K. Singh, Fabrice Confalonieri, Yvan Zivanovic, Ghislaine Allard, Mariana J. Awayez, Christina C.-Y. Chan-Weiher, Ib Groth Clausen, Bruce A. Curtis, Anick De Moors et al., „The Complete Genome of the Crenarchaeon Sulfolobus solfataricus P2”, Proceedings of the National Academy of Sciences USA 2001, vol. 98, s. 7835-7840.

${ }^{177}$ Por. Carlton, Hirt, Silva, Delcher, Schatz, Zhao, Wortman, Bidwell, Alsmark, Besteiro et al., „Draft Genome Sequence...”.

${ }^{178}$ Por. Koonin, „Evolution of Genome Architecture...”.

${ }^{179}$ Por. Koonin and Wolf, „Genomics of Bacteria and Archaea: The Emerging Generalizations After 13 Years...”; Erik van Nimwegen, „Scaling Laws in the Functional Content of Genomes", w: Eugene V. Koonin, Yuri I. Wolf, and Georgy P. Karev (eds.), Power Laws, Scale-Free Networks and Genome Biology, Landes Bioscience, Georgetown, Texas 2006, s. 236-253; Juan A.G. Ranea, Alastair Grant, Janet M. Thornton, and Christine A. Orengo, „Microeconomic Principles Explain an Optimal Genome Size in Bacteria”, Trends in Genetics 2005, vol. 21, s. 21-25.

${ }^{180}$ Por. Koonin and Wolf, „Genomics of Bacteria and Archaea: The Emerging Generalizations After 13 Years...”; van Nimwegen, „Scaling Laws...”; Erik van Nimwegen, „Scaling Laws in the Functional Content of Genomes", Trends in Genetics 2003, vol. 19, s. 479-484; Luke E. ULRich, Eugene V. Koonin, and Igor B. Zhulin, „One-Component Systems Dominate Signal Transduction in Prokaryotes", Trends in Microbiology 2005, vol. 13, s. 52-56.
} 
nych. Okazuje się jednak, że zgodnie z obecnie najspójniejszą, prostą hipotezą zerową ewolucji genomów rozbudowa genomu, warunek wstępny kompleksyfikacji, nie jest skutkiem adaptacji, lecz konsekwencją słabego doboru oczyszczającego.

Kolejne wielkie pytanie, jakie należy zadać odnośnie do problemu złożoności, zarówno organizacyjnej, jak i genomowej, jest następujące: czy w trakcie $\sim 3,5$ miliarda lat ewolucji życia na Ziemi istniał spójny trend ku wzrostowi złożoności? Najprawdopodobniejsza odpowiedź brzmi „nie”. Nawet bardzo konserwatywne rekonstrukcje ancestralnych genomów archeonów i bakterii wskazują, że te genomy były porównywalne rozmiarami i złożonością do genomów względnie prostych form współczesnych. ${ }^{181}$ Ponadto rekonstrukcje przeprowadzone dla pewnych indywidualnych grup, nie tylko pasożytów, wskazują na utratę genów i kurczenie się genomów jako dominujący trend ewolucji. ${ }^{182}$ Zważywszy na to, że liczne grupy prokariontów niewątpliwie wymarły w toku dziejów życia, istnieją wszelkie powody do uznania, że - nawet przed radiacją wszystkich znanych dzisiaj dużych linii rodowych — rozkład rozmiarów genów i średniej złożoności prokariontów był (niemal) taki sam jak obecnie. Oczywiście można sobie wyobrazić, że najbardziej złożone formy, jakie znamy, powstały w przebiegu ewolucji względnie późno, ale - gdyby rzeczywiście tak było - dałoby się to wyjaśnić działaniem procesów czysto stochastycznych, biorąc pod uwagę fakt, że życie, w etapach poprzedzających ewolucję LUCAS, musiało wywodzić się „, tak prostego początku”. ${ }^{183}$

W tym samym duchu odkrycie dużych i złożonych genomów u zwierząt macierzystych (to jest zwierząt o promienistej symetrii, takich jak parzydełkowce, które oddzieliły się od pnia ewolucji wielokomórkowców przed powstaniem

\footnotetext{
${ }^{181}$ Por. Snel, Bork, and Huynen, „Genomes in Flux...”; Mirkin, Fenner, Galperin, and KooNIN, „Algorithms for Computing...”; KunIN and OuzounIs, „The Balance of Driving Forces...”; Makarova, Sorokin, Novichkov, Wolf, and Koonin, „Clusters of Orthologous Genes...”.

${ }^{182}$ Por. Kira S. Makarova, Alexei I. Slessarev, Yuri I. Wolf, Alexander V. Sorokin, Boris G. Mirkin, Eugene V. Koonin, Andrey Pavlov, N. Pavlova, V. Karamychev, N. Polouchine et al., "Comparative Genomics of the Lactic Acid Bacteria", Proceedings of the National Academy of Sciences USA 2006, vol. 103, s. 15611-15616.

${ }^{183}$ Por. Darwin, O powstawaniu gatunków..., s. 450; Stephen Jay Gould, Full House: The Spread of Excellence from Plato to Darwin, Three Rivers Press, New York 1997.
} 
zwierząt dwubocznie symetrycznych ${ }^{184}$ ) wskazuje, że w trakcie ewolucji wielokomórkowców nastąpił niewielki, lub nawet zerowy, wzrost złożoności genomowej (aczkolwiek wrosła złożoność organizacyjna). Najbardziej dominującym procesem ewolucyjnym była zaś nawracająca utrata genów w różnych liniach rodowych.

Z pewnością znane są epizody dużych wzrostów złożoności, jak na przykład przy powstaniu eukariontów i form wielokomórkowych, by wymienić oczywiste przypadki. Nie wydają się one jednak stanowić części spójnego gradualistycznego trendu, lecz są jednostkowymi, mniej lub bardziej katastroficznymi zdarzeniami inicjowanymi przez rzadkie, przypadkowe zjawiska, takie jak oswojenie endosymbionta w wypadku powstania eukariontów.

Ogólnie rzecz biorąc, teoretyczne i empiryczne badania ewolucji złożoności genomowej wskazują, że w dziejach życia nie istniał żaden trend ku kompleksyfikacji i że gdy złożoność znacznie wzrasta, nie jest to skutek adaptacji. Jest to natomiast konsekwencja słabego doboru oczyszczającego, który — choć może wydawać się to paradoksalne - sam w sobie stanowi znamienną oznakę niepowodzenia ewolucji. Wydaje się, że te ustalenia wystarczą do odrzucenia idei „postępu” ewolucyjnego, co sugerowano wcześniej na ogólniejszych podstawach.

\section{Genomika funkcjonalna, biologia systemowa i determinanty tempa ewolucji genów}

Tak jak ostatnia dekada dwudziestego wieku była erą genomiki, podczas której liczbę sekwencji genomowych przekształcono w nową jakość, umożliwiając nowe uogólnienia, jak „wyrwanie z korzeniami” drzewa życia, tak pierwsza dekada kolejnego stulecia stała się erą genomiki funkcjonalnej i biologii systemowej. Dyscypliny te przynoszą coraz to wiarygodniejsze dane nowego typu, które zaczęły wypełniać rażącą dotąd lukę między genotypem a fenotypem organizmów (od tej chwili będę je nazywać zmiennymi fenomowymi). Zmienne

\footnotetext{
${ }^{184}$ Por. Putnam, Srivastava, Hellsten, Dirks, Chapman, Salamov, Terry, Shapiro, Lindquist, Kapitonov et al., „Sea Anemone Genome...”; Miller and Ball, „Cryptic Complexity Captured...”; Srivastava, Begovic, Chapman, Putnam, Hellsten, Kawashima, Kuo, Mitros, Salamov, CARPenter et al., „The Trichoplax Genome...”.
} 
fenomowe to między innymi utworzone na podstawie analizy całych genomów profile poziomów ekspresji genów, pełne mapy interakcji białko-białko i interakcji genetycznych, informacje o skutkach nokautowania genów (zbędność genów definiowana zwykle jako istotność danego genu dla wzrostu na bogatych pożywkach). ${ }^{185}$ Pierwsze analizy porównawcze, które stały się możliwe, gdy uzyskano dostateczne informacje o ekspresji genów u wielu organizmów, ujawniły wzajemną zależność między procesami neutralnymi a selekcyjnymi. Chociaż poziomy ekspresji między genami ortologowymi u ludzi i myszy ukazują znaczące utrwalenie (w porównaniu z losowymi parami genów), rozbieżność w ekspresji jest wyraźniejsza niż między białkowymi sekwencjami ortologów. ${ }^{186} \mathrm{~A}$ więc mimo że - ogólnie mówiąc - ewolucja ekspresji genów jest podobna do ewolucji sekwencji w tym, że dobór oczyszczający stanowi główną siłę ograniczającą, ${ }^{187}$ autentycznie neutralny, swobodny składnik prawdopodobnie pełni większą rolę w ewolucji ekspresji.

Połączona analiza nowej klasy zmiennych fenomowych opisanych przez biologię systemową oraz miar ewolucji genów, takich jak tempo ewolucji sekwencji i skłonność do utraty genów, ukazała dość niespodziewaną strukturę korelacji (por. rysunek 3A). ${ }^{188}$ Pomimo intuicyjnego związku między tempem ewolucji a zbędnością genów (,ważne” geny powinny ewoluować wolniej od mniej ważnych ${ }^{189}$ ), wykryto jedynie (w najlepszym wypadku) słaby związek

\footnotetext{
${ }^{185}$ Por. Koonin and Wolf, „Evolutionary Systems Biology: Links Between Gene Evolution and Function...”; Koonin and WoLf, „Evolutionary Systems Biology...”.

${ }^{186}$ Por. I. King Jordan, Leonardo Mariño-Ramírez, and Eugene V. Koonin, „Evolutionary Significance of Gene Expression Divergence”, Gene 2005, vol. 345, s. 119-126; Ben-Yang LiaO and Jianzhi Zhang, „Evolutionary Conservation of Expression Profiles Between Human and Mouse Orthologous Genes”, Molecular Biology and Evolution 2006, vol. 23, s. 530-540.

${ }^{187}$ Por. Philipp Khaitovich, Wolfgang Enard, Michael Lachmann, and Svante Pä̈̈вo, „Evolution of Primate Gene Expression", Nature Reviews Genetics 2006, vol. 7, s. 693-702.

${ }^{188}$ Por. Koonin and Wolf, „Evolutionary Systems Biology: Links Between Gene Evolution and Function..."; Dmitri M. Krylov, Yuri I. Wolf, Igor B. Rogozin, and Eugene V. Koonin, „Gene Loss, Protein Sequence Divergence, Gene Dispensability, Expression Level, and Interactivity Are Correlated in Eukaryotic Evolution”, Genome Research 2003, vol. 13, s. 2229-2235; Yuri I. Wolf, Liran CARMel, and Eugene V. Koonin, „Unifying Measures of Gene Function and Evolution”, Proceedings of the Royal Society of London B: Biological Sciences 2006, vol. 273, s. $1507-1515$.

${ }^{189}$ Por. Allan C. Wilson, Steven S. Carlson, and Thomas J. White, „Biochemical Evolution”, Annual Review of Biochemistry 1977, vol. 46, s. 573-639.
} 
między tymi zmiennymi. ${ }^{190}$ Związek między tempem ewolucji a funkcjonalnym znaczeniem danego genu zasługuje na dalsze badania, ponieważ wyczerpująca analiza ukazuje mierzalny fenotypowy efekt znokautowania prawie każdego genu drożdży w pewnych warunkach. ${ }^{191}$ Niezależnie jednak od wyniku takich badań, związek ten jest najwyraźniej subtelny, nawet jeśli okaże się silny. Natomiast najsilniejszą korelację we wszystkich porównaniach zmiennych ewolucyjnych i fenomowych dostrzeżono między poziomem ekspresji genów a tempem ewolucji sekwencji lub skłonnością do utraty genów: geny o wysokiej ekspresji rzeczywiście mają tendencję do znacznie szybszej ewolucji niż geny o niskiej ekspresji. ${ }^{192}$ Odkrycie to wzmacniają obserwacje pozytywnej korelacji między dywergencją sekwencji a dywergencją profilów ekspresji pośród ludzkich i mysich genów ortologowych ${ }^{193}$ oraz stosunkowo niskiego tempa dywergencji profilów ekspresji genów cechujących się wysoką ekspresją. ${ }^{194}$

Ogólną strukturę korelacji między zmiennymi ewolucyjnymi a fenomowymi zwięźle ujmuje pojęcie „statusu” genów w genomie. ${ }^{195}$ Geny o wysokim statusie ewoluują wolniej, rzadziej są tracone w toku ewolucji i zwykle cechują się wysoką ekspresją, wchodząc w wiele interakcji białko-białko i interakcji genetycznych i mając liczne paralogi (por. rysunek 3B). Należy jednak zauważyć, że pomimo tego obserwowanego uporządkowania w strukturze korelacji, wszystkie

\footnotetext{
${ }^{190}$ Por. Laurence D. Hurst and Nick G.C. SмIтн, „Do Essential Genes Evolve Slowly?”, Current Biology 1999, vol. 9, s. 747-750; Aaron E. HIRSH and Hunter B. Fraser, „Protein Dispensability and Rate of Evolution”, Nature 2001, vol. 411, s. 1046-1049; I. King JoRDan, Igor B. Rogozin, Yuri I. Wolf, and Eugene V. Koonin, „Essential Genes Are More Evolutionarily Conserved Than Are Nonessential Genes in Bacteria”, Genome Research 2002, vol. 12, s. 962-968.

${ }^{191}$ Por. Maureen E. Hillenmeyer, Eula Fung, Jan Wildenhain, Sarah E. Pierce, Shawn Hoon, William Lee, Michael Proctor, Robert P. St. Onge, Mike Tyers, Daphne Koller et al., „The Chemical Genomic Portrait of Yeast: Uncovering a Phenotype for All Genes”, Science 2008, vol. 320, s. 362-365.

${ }^{192}$ Por. Krylov, Wolf, Rogozin, and Koonin, „Gene Loss...”; Csaba PÁl, Balázs PAPp, and Laurence D. Hurst, „Highly Expressed Genes in Yeast Evolve Slowly”, Genetics 2001, vol. 158, s. $927-931$

${ }^{193}$ Por. Liao and Zhang, „Evolutionary Conservation...”.

${ }^{194}$ Por. Ben-Yang Liao and Jianzhi Zhang, „Low Rates of Expression Profile Divergence in Highly Expressed Genes and Tissue-Specific Genes During Mammalian Evolution”, Molecular Biology and Evolution 2006, vol. 23, s. 1119-1128.

${ }^{195}$ Por. Wolf, CARmel, and Koonin, „Unifying Measures...”.
} 
korelacje są względnie słabe i ich siła nie rośnie znacznie w miarę udoskonalania jakości danych. ${ }^{196}$ Obserwacje te wskazują na wielorakość determinantów przebiegu ewolucji genów i prowadzą do przypuszczenia, że istotnym czynnikiem może być prawdziwie losowy, stochastyczny szum.

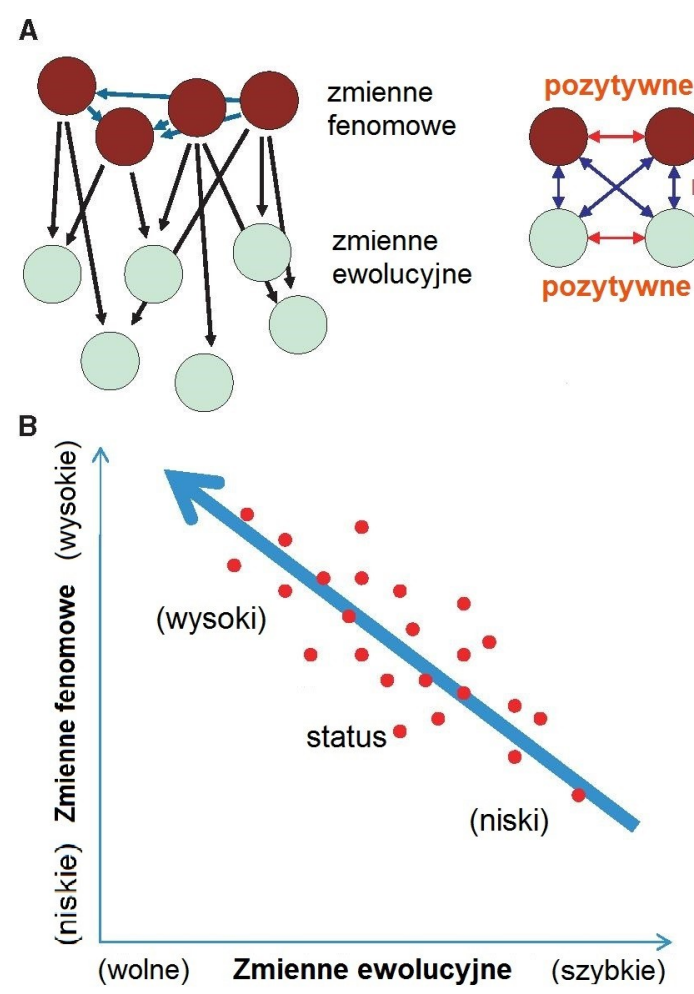

Rys. 3. Genomika ewolucyjna i biologia systemowa. (A) Zmienne ewolucyjne i fenomowe. Zmienne fenomowe postrzega się jako wzajemnie od siebie zależne i wpływające na zmienne ewolucyjne (po lewej). Pozytywne korelacje przedstawione są za pomocą czerwonych strzałek, a korelacje negatywne za pomocą strzałek niebieskich. (B) Pojęcie statusu genu. Czerwone punkty schematycznie przedstawiają rozrzut danych.

Pojawienie się związku między tempem ewolucji sekwencji jako najbardziej wyróżniający się związek między zmiennymi ewolucyjnymi a fenomowymi do-

${ }^{196}$ Por. Krylov, Wolf, Rogozin, and Koonin, „Gene Loss...”; Wolf, Carmel, and Koonin, „Unifying Measures...”. 
prowadziło do nowej koncepcji głównych determinantów ewolucji białek. W erze przedgenomicznej na ogół zakładano, że tempo ewolucji sekwencji powinno być funkcją, po pierwsze, wewnętrznych ograniczeń strukturalno-funkcjonalnych, które wpływają na dane białko, i, po drugie, znaczenia biologicznej roli tego białka w organizmie. ${ }^{197}$ Wraz z nastaniem biologii systemowej uświadomiono sobie, że zmienne fenomowe, zwłaszcza ekspresja genów, mogą być równie lub nawet bardziej ważne niż czynniki rozważane tradycyjnie. ${ }^{198}$ Stąd wzięła się hipoteza Błędnego Sfałdowania Wywołanego Błędną Translacją (MIM - Mistranslation-Induced Misfolding), zgodnie z którą poziom ekspresji lub, ściślej rzecz biorąc, tempo zdarzeń translacyjnych rzeczywiście stanowi dominujące uwarunkowanie tempa ewolucji sekwencji. Za przyczynę kowariancji między tempem ewolucji sekwencji a poziomem ekspresji uznaje się selekcję w kierunku odporności na błędne fałdowanie białek, której znaczenie wzrasta dla białek o wysokiej ekspresji ze względu na szkodliwe skutki błędnie sfałdowanych białek. ${ }^{199}$ Hipoteza MIM może dodatkowo thumaczyć dość zagadkową, ale spójną i silną pozytywną korelację między tempem ewolucji w synonimicznych i niesynonimicznych pozycjach (odpowiednio - $\mathrm{d} N \mathrm{i} \mathrm{d} S$ ) sekwencji kodujących białka. ${ }^{200} \mathrm{~W}$ rzeczy samej, ta korelacja jest prawdopodobnie konsekwencją powolnej ewolucji w obu tych klasach miejsc w genach o wysokiej ekspresji, która to ewolucja — w przypadku miejsc synonimicznych — jest zapewne spowodowana przez selekcję kodonów minimalizujących błędną translację. ${ }^{201}$

${ }^{197}$ Por. Wilson, CARLSON, and White, „Biochemical Evolution...”.

${ }^{198}$ Por. Csaba PÁL, Balázs PAPP, and Martin J. Lercher, „An Integrated View of Protein Evolution”, Nature Reviews Genetics 2006, vol. 7, s. 337-348; James O. McInerneY, „The Causes of Protein Evolutionary Rate Variation", Trends in Ecology and Evolution 2006, vol. 21, s. 230-232.

${ }^{199}$ Por. D. Allan Drummond, Jesse D. Bloom, Christoph Adami, Claus O. Wilke, and Frances H. Arnold, „Why Highly Expressed Proteins Evolve Slowly”, Proceedings of the National Academy of Sciences USA 2005, vol. 102, s. 14338-14343; D. Allan Drummond, Alpan Raval, and Claus O. WILKe, „A Single Determinant Dominates the Rate of Yeast Protein Evolution”, Molecular Biology and Evolution 2006, vol. 23, s. 327-337.

${ }^{200}$ Por. Wojciech MakaŁowski and Mark S. Boguski, „Evolutionary Parameters of the Transcribed Mammalian Genome: An Analysis of 2,820 Orthologous Rodent and Human Sequences", Proceedings of the National Academy of Sciences USA 1998, vol. 95, s. 9407-9412.

${ }^{201}$ Por. I. King Jordan, Leonardo Mariño-Ramírez, Yuri I. Wolf, and Eugene V. Koonin, „Conservation and Coevolution in the Scale-Free Human Gene Coexpression Network”, Molecular Biology and Evolution 2004, vol. 21, s. 2058-2070; D. Allan Drummond and Claus O. WiLKe, „Mistranslation-Induced Protein Misfolding as a Dominant Constraint on Coding-Sequence Evo- 
Szczegółowe symulacje komputerowe ewolucji białek wskazują, że szkodliwy skutek błędnie zwiniętych białek rzeczywiście może wystarczyć do wyjaśnienia obserwowanej kowariancji poziomu ekspresji i tempa ewolucji sekwencji. ${ }^{202}$ Analiza ewolucji białek wielodomenowych ukazała znaczną homogenizację tempa ewolucji specyficznego dla domen w porównaniu z tą samą parą domen u odrębnych białek. Jak można przypuszczać, da się to przypisać wyrównanemu tempu translacji, jednak duże różnice między tempem ewolucji specyficznym dla domen utrzymywały się nawet w przypadku białek wielodomenowych. ${ }^{203}$ W ten sposób dochodzimy do uogólnionej hipotezy MIM, zgodnie z którą tempo ewolucji białek zależy głównie od dwóch czynników:

i. Wewnętrznej odporności na błędne fałdowanie, która jest zależna od charakterystycznej trwałości i projektowalności danego białka (domeny).

ii. Tempa translacji, które można postrzegać jako amplifikator kosztów dostosowania towarzyszących błędnemu fałdowaniu i — odpowiednio — jako amplifikator selekcji w kierunku odporności na błędne przyłączenie aminokwasów.

Ewolucyjna biologia systemowa ujawniła nową warstwę związków między ewolucją a funkcjonowaniem genomu. Staje się jasne, że procesy łączące genom i fenotyp organizmu, zwłaszcza ekspresja genów, prowadzą do istotnego sprzężenia zwrotnego w ewolucji genów. Tempo ewolucji genów kodujących białka może zależeć bardziej od ograniczeń związanych z zapobieganiem szkodliwym skutkom błędnego sfałdowania niż od ograniczeń towarzyszących specyficznym funkcjom białek.

\section{Powszechniki ewolucji genomów}

Genomika porównawcza i biologia systemowa zapewniają ogromną liczbę

\footnotetext{
lution”, Cell 2008, vol. 134, s. 341-352.

${ }^{202}$ Por. DRummond and WILKE, „Mistranslation-Induced Protein Misfolding...”.

${ }^{203}$ Por. Maxim Y. Wolf, Yuri I. Wolf, and Eugene V. Koonin, „Comparable Contributions of Structural-Functional Constraints and Expression Level to the Rate of Protein Sequence Evolution", Biology Direct 2008, vol. 3, no. 40.
} 
danych, a to bogactwo informacji aż prosi się o poszukiwanie wzorców i prawidłowości. W istocie odkryto różne takie prawidłowości, które są rozpowszechnione i mogą być nawet uniwersalne w całym przebiegu ewolucji życia. W poprzedniej części omówiłem jeden z takich wyraźnych powszechników — negatywną korelację między tempem ewolucji sekwencji genów a poziomem ekspresji - występujący najwyraźniej u wszystkich organizmów, dla których posiadamy odpowiednie dane, i zmuszający do ponownej oceny czynników wpływających na ewolucję genów. ${ }^{204}$

Inne potencjalne, ważne prawidłowości przybierają postać utrwalonych rozkładów zmiennych ewolucyjnych i funkcjonalnych. Co uderzające, ustalono, że rozkłady tempa ewolucji sekwencji genów ortologowych między blisko spokrewnionymi genomami są bardzo podobne w różnych taksonach. ${ }^{205}$ Po standaryzacji rozkłady te są praktycznie nieodróżnialne u bakterii, archeonów i eukariontów, a ich najlepszym przybliżeniem jest rozkład logarytmicznie normalny (por. rysunek 4A). Zważywszy na radykalne różnice w złożoności genomowej i architekturze (por. wyżej), jak również na biologię tych organizmów, to, że rozkłady tempa są niemal identyczne, jest zaskakujące i domaga się wyjaśnienia poprzez odwołanie do uniwersalnych czynników wpływających na ewolucję genomów. Omówiona wyżej odporność na błędne fałdowanie białek wydaje się dobrym kandydatem na taki uniwersalny czynnik, chociaż należy jeszcze opracować ilościowe modele wyjaśniające rozkłady tempa.

Jak wspomniałem wyżej, duplikacja genów kształtuje wszystkie genomy, zaś rozkład rozmiaru rodzin we wszystkich zsekwencjonowanych genomach jest zgodny z rozkładem wykładniczym, przy czym jedyną zauważalną różnicę stanowi wykładnik. ${ }^{206}$ Tak więc rozkład ten wydaje się powszechnikiem ewolucji genomów. Ponadto dobrze mu odpowiada prosty model narodzin i śmierci odnośnie do ewolucji genów, w którym mowa jest o zrównoważonym tempie na-

\footnotetext{
${ }^{204}$ Por. Drummond and WiLKE, „Mistranslation-Induced Protein Misfolding...”.

${ }^{205}$ Por. Nick V. Grishin, Yuri I. Wolf, and Eugene V. Koonin, „From Complete Genomes to Measures of Substitution Rate Variability Within and Between Proteins", Genome Research 2000, vol. 10, s. 991-1000.

${ }^{206}$ Por. Huynen and van Nimwegen, „The Frequency Distribution...”; Karev, Wolf, Rzhetsky, Berezovskaya, Koonin, „Birth and Death of Protein Domains...”.
} 
rodzin i śmierci przy braku bezpośredniego wpływu jakiejkolwiek formy selekcji (por. rysunek 4B). ${ }^{207}$

Skalowanie niezrównoważone funkcjonalnych klas genów przy wspomnianym wyżej rozmiarze genomu wskazuje na istnienie całego zbioru fundamentalnych stałych ewolucji. Stosunki tempa duplikacji do tempa eliminacji genów, które określają wykładniki rozkładu wykładniczego dla każdej klasy genów, wydają się takie same dla wszystkich linii rodowych prokariontów i niezmiennicze w czasie, a związku z tym funkcjonalne klasy genów najwyraźniej posiadają uniwersalne ,potencjały ewolucyjne”. ${ }^{208}$

Wyraźna uniwersalność tych i innych podstawowych cech ewolucji genomów wskazuje, że względnie proste nieselekcjonistyczne modele mogą wystarczyć do utworzenia ramy ogólnej teorii ewolucji, w której dobór oczyszczający zapewniałby warunki brzegowe (ograniczenia), zaś pozytywny, darwinowski dobór (adaptacja) jawiłby się jako ilościowo skromny, choćby nawet i kluczowy pod względem funkcjonalnym, modulator procesu ewolucji.

\section{Wnioski}

200 lat od narodzin Darwina, 150 lat od publikacji jego O powstawaniu gatunków i 50 lat od skonsolidowania Nowoczesnej Syntezy analiza porównawcza setek genomów należących do wielu różnych taksonów oferuje niespotykane możliwości testowania przypuszczeń (neo)darwinizmu i odszyfrowania mechanizmów ewolucji. Genomika porównawcza ujawniła uderzającą różnorodność procesów ewolucyjnych, co było niewyobrażalne w erze przedgenomicznej. Poza mutacjami punktowymi, które można utożsamić z „maleńkimi przekształceniami”, o jakich mówił Darwin, duży wkład w ewolucję genomów zapewniają duplikacje genów i całych genomów, duże delecje, w tym utrata genów lub grup genów, horyzontalny transfer genów i całych regionów genomu, różne typy przeorganizowania genomów oraz interakcje między genomami ko-

\footnotetext{
${ }^{207}$ Por. Karev, Wolf, Rzhetsky, Berezovskaya, Koonin, „Birth and Death of Protein Domains...”; Eugene V. Koonin, Yuri I. Wolf, and Georgy P. Karev, „The Structure of the Protein Universe and Genome Evolution", Nature 2002, vol. 420, s. 218-223.

${ }^{208}$ Por. van Nimwegen, „Scaling Laws...”; Nacho Molina and Erik van Nimwegen, „The Evolution of Domain-Content in Bacterial Genomes”, Biology Direct 2008, vol. 3, no. 51.
} 
mórkowych form życia a rozmaitymi samolubnymi elementami genetycznymi. Ważnym składnikiem wyłaniającego się krajobrazu ewolucji genomów nadal jest klasyczny, darwinowski dobór naturalny, lecz jest to krajobraz znacznie bardziej pluralistyczny i złożony niż przewidywała prosta wizja Darwina wzmocniona przez Nowoczesną Syntezę. ${ }^{209}$ Większość sekwencji we wszystkich genomach ewoluuje pod presją doboru oczyszczającego lub — w przypadku organizmów posiadających największe genomy - neutralnie, przy czym tylko mała część mutacji rzeczywiście jest, wbrew przewidywaniom Darwina, korzystna i utrwalana przez dobór naturalny. Ponadto względny wkład różnych sił ewolucyjnych bardzo różni się między liniami rodowymi organizmów, głównie ze względu na różnice w strukturze populacji.

Genomika ewolucyjna skutecznie obaliła prostą koncepcję drzewa życia, ujawniając dynamiczny, posiatkowany charakter ewolucji, w której główną rolę odgrywają HGT, fuzja genomów oraz interakcje między genomami komórkowych form życia a różnymi samolubnymi elementami genetycznymi. W świetle tego dynamicznego światopoglądu każdy genom stanowi palimpsest, zróżnicowaną kolekcję genów o różnych losach ewolucyjnych i bardzo różniących się prawdopodobieństwami ich utraty, transferu lub zduplikowania. Tak więc drzewo życia staje się siecią lub być może — najstosowniej — lasem życia składającym się z drzew, krzaków, gąszczu lian i oczywiście licznych martwych pni i gałęzi. Otwartą kwestią pozostaje, czy da się ocalić drzewo życia jako główny trend ewolucji wielu utrwalonych genów, czy też koncepcję tę należy zupełnie porzucić na rzecz idei lasu życia. ${ }^{210}$

Tabela 1 przedstawia status głównych twierdzeń klasycznej biologii ewolucyjnej w erze genomiki ewolucyjnej i biologii systemowej. Wszystkie klasyczne koncepcje uległy przekształceniu, zmieniając się w znacznie bardziej złożone, pluralistyczne opisy procesu ewolucji. ${ }^{211}$ Opiszmy tę zmianę możliwie najogól-

\footnotetext{
${ }^{209}$ Por. Lynch, The Origins of Genome Architecture...; Lynch, „The Frailty of Adaptive Hypotheses...".

${ }^{210}$ Por. Maureen A. O’Malley and Yan Boucher, „Paradigm Change in Evolutionary Microbiology”, Studies in History and Philosophy of Science Part C: Studies in History and Philosophy of Biological and Biomedical Sciences 2005, vol. 36, s. 183-208.

${ }^{211}$ Por. Rose and OAKLeY, „The New Biology...”.
} 
A
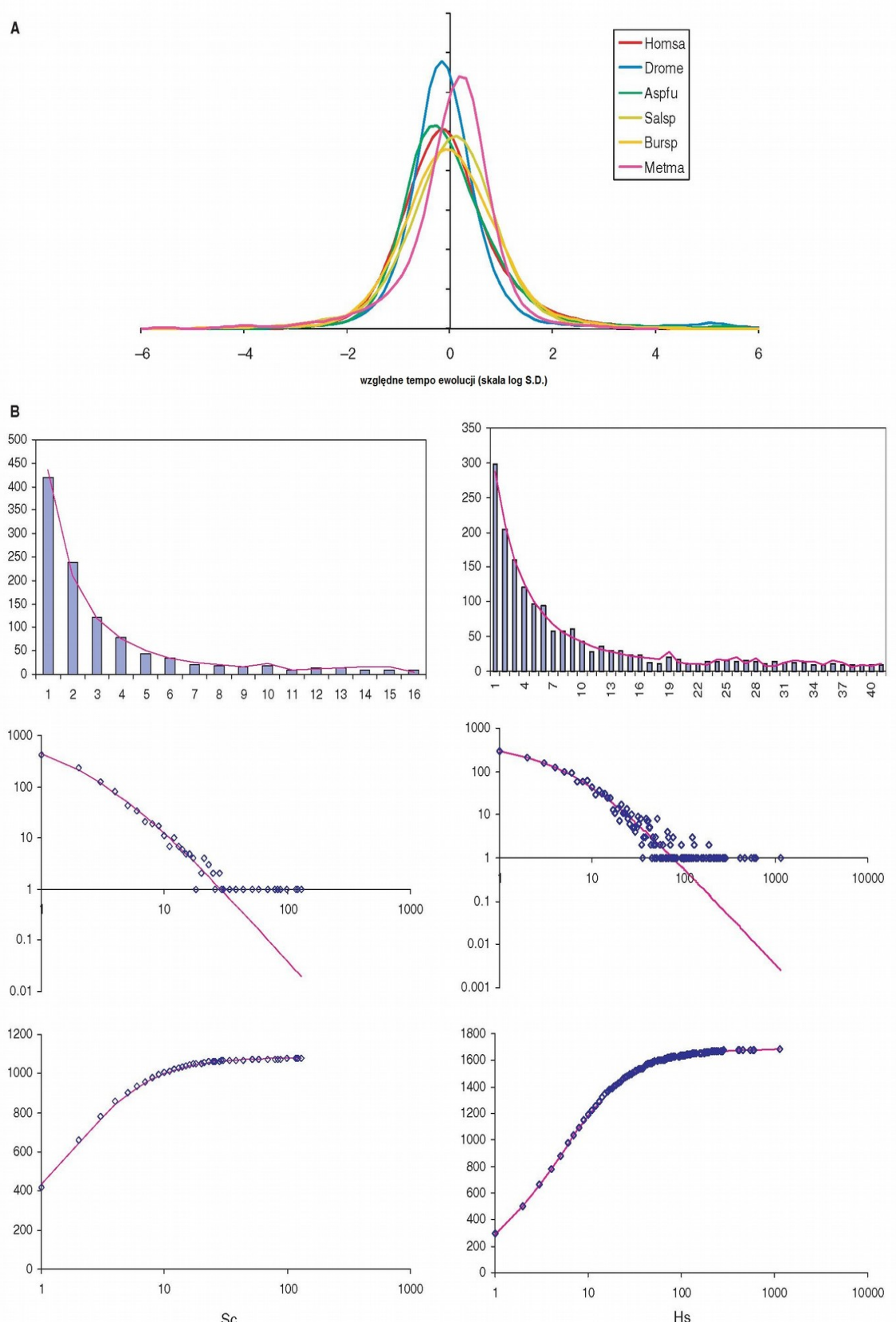
Rys. 4. Powszechniki ewolucji. (A) Rozkłady tempa ewolucji między ortologami w parach genomów bakterii, archeonów i eukariontów. Ewolucyjne odległości między porównywanymi sekwencjami nukleotydów genów ortologowych obliczono przy użyciu poprawki Jukesa-Cantora i tak znormalizowano, aby średnia każdego rozkładu była równa 0 , zaś standardowe odchylenie wynosiło 1 . Wykres jest semilogaryt miczny. Metma - Methanococcus maripaludis C5 versus M. maripaludis C7 (Euryarcheony); Bursp - Burkholderia cenocepacia MC0-3 versus B. vietnamiensis G4 (Proteobakterie); Salsp - Salinispora arenicola CNS-205 versus S. tropica CNB-440 (Aktynobakterie). Wszystkie sekwencje pochodzą z bazy danych NCBI RefSeq. Krzywe gęstości prawdopodobieństwa otrzymano za pomocą ziarnistego rozmycia gaussowskiego pojedynczych punktów danych. (B) Dostosowanie empirycznych rozkładów rozmiarów rodzin genów paralogowych do zrównoważonego modelu narodzin i śmierci. Pokazane wyniki dotyczą drożdży Saccharomyces cerevisiae (Sc, po lewej) i ludzi (Hs, po prawej). Górne wykresy przedstawiają słupkowe rozkłady rozmiarów rodzin genów paralogowych; środkowe wykresy ukazują rozkłady rozmiarów rodzin genów paralogowych wyrażone podwójnymi współrzędnymi logarytmicznymi; dolne wykresy pokazują funkcję kumulatywnego rozkładu rozmiarów rodzin genów paralogowych. Linie przedstawiają przewidywania zrównoważonego modelu narodzin i śmierci. Rysunek zaczerpnięto z: Karev, Wolf, Rzhetsky, BerezovsKaya, and Koonin, „Birth and Death of Protein Domains...".

niej: najważniejsze spostrzeżenie Darwina na temat wzajemnej zależności przypadku i porządku (uzyskiwanego przez działanie doboru naturalnego) przetrwało, nawet jeśli w nowej, znacznie bardziej złożonej i subtelnej formie, obejmującej szczególny wkład różnych typów procesów losowych i selekcji. Natomiast nacisk na to, by adaptacja była głównym trybem ewolucji — widoczny w $\mathbf{O}$ powstawaniu gatunków, ale zwłaszcza w Nowoczesnej Syntezie - stał się zachowaniem mocno podejrzanym, lub nawet anachronicznym, i ustąpił miejsca nowemu światopoglądowi, który znacznie większe znaczenie nadaje procesom nieadaptacyjnym. ${ }^{212}$

Czy poza zdumiewającą, nieoczekiwaną różnorodnością organizacji genomów i trybów ewolucji, ujawnioną przez genomikę porównawczą, istnieje szansa odkrycia tkwiących u podstaw ogólnych zasad? Czy może jednak jedyną taką zasadą jest kluczowa rola przypadku i przygodności w ewolucji, elegancko ujęta przez Jacoba ${ }^{213}$ w metaforze „ewolucji jako majsterkowania”? Kusi, by zadać nieco ironiczne pytanie: czy Postnowoczesna Synteza jest możliwa do wyobrażenia? A może już znajduje się w zasięgu wzroku?

\footnotetext{
${ }^{212}$ Por. LynCH, „The Frailty of Adaptive Hypotheses...”.

${ }^{213}$ Por. JACOB, „Evolution and Tinkering...”.
} 
Tab. 1. Status głównych twierdzeń darwinizmu i Nowoczesnej Syntezy w świetle genomiki ewolucyjnej ${ }^{\text {a }}$

\section{Twierdzenie} Materiał dla ewolucji dostarczany
jest głównie przez losowe, dziedziczne zmiany

Utrwalanie (rzadkich) korzystnych zmian przez dobór naturalny stanowi główną siłę napędową ewolucji, która na ogół tworzy coraz bardziej złożone cechy przystosowawcze organizmów, a stąd można mówić o postępie jako ogólnym trendzie ewolucji

Zmiany utrwalane przez dobór naturalny są „nieskończenie małe”. Ewolucja ma charakter gradualistyczny

Uniformitarianizm: procesy ewolucyjne były na ogół takie same w trakcie całej ewolucji życia

Całą ewolucję życia można przedstawić jako jedno ,drzewo życia”
Obecny status

Prawda. Repertuar istotnych losowych zmian bardzo się rozrósł, obejmując duplikację genów, regionów genomów i całych genomów; utratę genów i, ogólnie, materiału genetycznego; HGT, w tym masowy przepływ genów w przypadkach endosymbiozy; inwazję samolubnych elementów ruchomych i werbowanie sekwencji z nich; a także więcej

Fałsz. Dobór naturalny (pozytywny) jest ważnym czynnikiem ewolucji, ale stanowi tylko jedna z wielu podstawowych sił i nie jest ilościowo dominujący, ponieważ to procesy neutralne połączone $\mathrm{z}$ działaniem doboru oczyszczajacego dominuja w procesie ewolucji. Złożoność genomowa prawdopodobnie wyewoluowała jako „genomowy syndrom” spowodowany słabym doborem oczyszczającym w małych populacjach, nie zaś jako adaptacja. Nie istnieje żaden spójny trend ku wzrastaniu złożoności w procesie ewolucji, a pojęcie postępu ewolucyjnego nie ma żadnych podstaw

Fałsz. Nawet duplikacje i HGT pojedynczych genów, a tym bardziej delecje lub uzyskiwanie większych regionów, przeorganizowania genomów, duplikacje całych genomów $\mathrm{i}$ - w najskrajniejszym przypadku endosymbioza, nie są w żadnej mierze „nieskończenie małe". Gradualizm nie stanowi głównego reżimu ewolucji

W dużej mierze prawda. Jednak najwcześniejsze stadia ewolucji (poprzedzające LUCA) prawdopodobnie obejmowały różne procesy, które nie wystepowały w późniejszej, „normalnej” ewolucji. Wielkie przejścia w ewolucji, takie jak powstanie eukariontów, mogły być skutkiem (naprawde) unikatowych zdarzeń, na przykład endosymbiozy

Fałsz. Odkrycie fundamentalnego wkładu HGT i ruchomych elementów genetycznych w ewolucję genomów unieważnia koncepcję drzewa życia w jej pierwotnym znaczeniu. Drzewa nadal odgrywają jednak rolę istotnych schematów przedstawiajacych ewolucję pojedynczych genów i wielu faz ewolucji w grupach względnie blisko spokrewnionych organizmów. Wciąż istnieje możliwość ocalenia drzewa życia jako głównego trendu ewolucji 
Wszystkie istniejace obecnie formy życia pochodzą od bardzo niewielu, a prawdopodobnie od jednej formy ancestralnej (LUCA)
Prawda. Genomika porównawcza nie pozostawia wątpliwości na temat wspólnoty pochodzenia życia komórkowego. Wskazuje jednak również na to, że LUCA(S) mógł być bardzo odmienny od współczesnych komórek

a Treść sześciu przeanalizowanych tutaj fundamentalnych twierdzeń (neo)darwinizmu jest taka sama jak we Wprowadzeniu. Łączę tu twierdzenia Darwina z O powstawaniu gatunków z twierdzeniami Nowoczesnej Syntezy. Rozróżnienie między nimi jest pouczające, lecz objaśnienie tej kwestii wymaga znacznie pełniejszego ujęcia historycznego. Głębokie, choć być może idiosynkratyczne, omówienie różnic między nimi można znaleźć w: Gould, The Structure of Evolutionary Theory....

Pewne niedawne ustalenia w dziedzinie genomiki ewolucyjnej mogą kandydować do roli uogólnień wyższego rzędu leżących u podstaw różnorodności procesów ewolucyjnych. Być może najdalej idącym z nich jest populacyjnogenetyczna koncepcja ewolucji genomu sformułowana przez Lyncha. ${ }^{214}$ Zgodnie z nią główne cechy genomu kształtowane są nie przez adaptację, lecz przez stochastyczne procesy ewolucyjne, które nieuchronnie zależą od intensywności działania doboru oczyszczającego determinowanego, z kolei, przez rzeczywisty rozmiar populacji i tempo mutacji odpowiednich organizmów. W szczególności złożoność genomów wielokomórkowych eukariontów interpretuje się jako rezultat ewolucji przebiegającej nie, głównie, na zasadzie adaptacji zapewniającej złożoność organizacyjną i funkcjonalną, lecz na zasadzie „,genomowego syndromu" spowodowanego nieskutecznym działaniem doboru oczyszczającego w małych populacjach. Niektóre elementy sekwencji nagromadzane drogą procesów neutralnych są następnie werbowane do pełnienia funkcji biologicznych, które wspólnie, w gruncie rzeczy, prowadzą do ewolucji strukturalnie i funkcjonalnie złożonych organizmów. I odwrotnie: upakowane genomy prokariontów i niektórych jednokomórkowych eukariontów mogą nie być kształtowane przez selekcję w kierunku „usprawniania genomów”, lecz przez skuteczne ulepszanie nawet nieznacznie szkodliwych sekwencji w dużych populacjach. ${ }^{215}$ Nieadaptacjonistyczny pogląd na ewolucję złożoności genomowej nie implikuje oczywiście, że żadne złożone cechy nigdy nie ewoluują jako bezpośrednie adaptacje lub że usprawnianie genomów nigdy nie może stanowić głównej siły napędowej

\footnotetext{
${ }^{214}$ Por. LYNCH, The Origins of Genome Architecture....

${ }^{215}$ Por. Koonin and Wolf, „Genomics of Bacteria and Archaea: The Emerging Generalizations After 13 Years...".
} 
ewolucji genomów. Sądzę jednak, że dane empiryczne zgromadzone w ramach genomiki ewolucyjnej wystarczają do wymuszenia zmiany centralnej hipotezy zerowej co do ewolucji genomów z adaptacjonistycznej na neutralistyczną, przy czym ciężar dowodu spada na zwolenników koncepcji wszechobecnej adaptacji. ${ }^{216}$

Koncepcja zasadniczo nieadaptacyjnego charakteru ewolucji genomów rzeczywiście zdaje się wpływać na nasze podstawowe rozumienie znaczenia utrwalania cech genomowych. Oto świetny przykład: dość zagadkowe utrwalenie pozycji dużej części intronów w trakcie ewolucji eukariontów może nie być konsekwencją działania silnego doboru oczyszczającego, który powodowałby eliminację wariantów z utraconymi odpowiednimi intronami (jest to domyślna interpretacja sugerowana przez samo pojęcie doboru oczyszczającego, w pełni zgodna $z$ teorią neutralną). Przeciwnie, utrwalanie intronów i innych cech genomowych niepełniących ewidentnych funkcji może być konsekwencją działania słabego doboru oczyszczającego w małych populacjach złożonych organizmów, który nie jest w stanie skutecznie usunąć tych elementów. Nie jest to równoznaczne ze stwierdzeniem, że wiele cech genomowych (takich jak pojedyncze geny, reszty aminokwasowe ${ }^{*}$ lub nukleotydy) nie jest utrwalanych podczas ewolucji ze względu na ich znaczenie funkcjonalne. Jest to natomiast sugestia, że nawet to „święte”, główne twierdzenie biologii ewolucyjnej — „to, co ulega utrwaleniu, ma znaczenie funkcjonalne" - nie jest bezwzględnie prawdziwe, zaś alternatywę nieadaptacjonistyczną należy traktować poważnie. Jeżeli uświadomimy sobie ponadto, że kurczenie się genomów jest w ewolucji zjawiskiem co najmniej równie częstym, jak ich rozbudowa, i że wzrost złożoności genomowej nie stanowi głównego trendu ewolucyjnego, to koncepcja nieadaptacyjnej ewolucji genomów implikuje, że można bezpiecznie porzucić ideę postępu ewolucyjnego.

Niekiedy argumentuje się, że ostatnie odkrycia genomiki i biologii systemowej tworzą labirynt związków między różnymi rodzajami danych, które są trudne do rozwiązania w jakiś jednoznaczny sposób, co niweczy nadzieje na odkrycie prostych, „prawopodobnych” prawidłowości i redukuje możliwości badań

\footnotetext{
${ }^{216}$ Por. Koonin, „A Non-Adaptationist Perspective on Evolution...”.

* (Przyp. tłum.) Reszty aminokwasowe - tak zgodnie z oryginałem.
} 
w tych obszarach, które mogłyby doprowadzić do opracowania algorytmów predykcyjnych. ${ }^{217}$ To jednak właśnie ten rodzaj prostych i najwyraźniej uniwersalnych prawidłowości wyłania się z połączonej analizy danych dostarczanych przez genomikę porównawczą i biologię systemową. Rozkład tempa ewolucji w zbiorach genów ortologowych, rozkład rozmiarów rodzin genów paralogowych, negatywna korelacja między poziomem ekspresji a tempem ewolucji sekwencji danego genu, a także inne związki między kluczowymi zmiennymi ewolucyjnymi i fenomowymi zdają się stanowić autentyczne powszechniki ewolucji. Prostota tych uniwersalnych prawidłowości wskazuje na to, że zostały one ukształtowane przez równie proste, podstawowe procesy ewolucyjne, nie zaś przez selekcję w kierunku specyficznych funkcji. W pewnych przypadkach modele takich procesów zostały już opracowane i wykazano, że są one zgodne z danymi. Modele te bądź w ogóle nie obejmują selekcji, bądź nadają jej nową interpretację. Dobry przykład stanowi uogólniona hipoteza błędnego fałdowania wywołanego błędną translacją, która wyjaśnia kowariancję ekspresji genów i tempa ewolucji sekwencji poprzez potraktowanie selekcji w kierunku odporności na błędne fałdowanie jako głównego wyznacznika ewolucji białek. Niespodziewanym następstwem tego modelu jest to, że główną siłą napędową doboru oczyszczającego może nie być utrzymywanie funkcji biologicznej, lecz ochrona przed niespecyficznymi, szkodliwymi skutkami błędnie sfałdowanych białek.

Zarysowane tutaj ustalenia genomiki ewolucyjnej i biologii systemowej wskazują, że chociaż obecnie formułowane są dopiero izolowane elementy nowej, „postnowoczesnej” syntezy biologii ewolucyjnej, synteza taka naprawdę może zostać zrealizowana. Co więcej, jest całkiem prawdopodobne, że ostateczny kształt przyjmie ona długo przed 250 rocznicą narodzin Darwina.

\section{Podziękowania}

Dziękuję Valerianowi Dojli, Allanowi Drummondowi, Davidowi Lipmanowi, Michaelowi Lynchowi, Tanii Senkevich, Clausowi Wilkemu i Yuriemu Wolfowi za wiele pomocnych dyskusji, Tanii Senkevich za krytyczną lekturę

\footnotetext{
${ }^{217}$ Por. Lawrence L. Kelley and Michael Sсотт, „The Evolution of Biology: A Shift Towards the Engineering of Prediction-Generating Tools and Away from Traditional Research Practice", EMBO Reports 2008, vol. 9, s. 1163-1167.
} 
maszynopisu i Yuriemu Wolfowi za pomoc w przygotowaniu rysunków.

\section{Finansowanie}

Wewnętrzne fundusze Department of Health and Human Services (National Institutes of Health, National Library of Medicine). Sfinansowanie opłaty za otwarty dostęp do artykułu: wewnętrzne fundusze Department of Health and Human Services (National Institutes of Health, National Library of Medicine).

Oświadczenie o konflikcie interesów: nie zgłoszono żadnego.

Eugene V. Koonin

\section{Bibliografia}

AdAmi Christoph, „What is Complexity?”, BioEssays 2002, vol. 24, s. 1085-1094.

Amaral Paulo P., Dinger Marcel, Mercer Tim R., and Mattick John S., „The Eukaryotic Genome as an RNA Machine", Science 2008, vol. 319, s. 1787-1789.

Andersson Jan O., „Lateral Gene Transfer in Eukaryotes”, Cellular and Molecular Life Sciences 2005, vol. 62, s. 1182-1197.

Andersson Jan O., Suögren Åsa, Horner David S., Murphy Colleen A., Dyal Patricia L., Svärd Staffan G., Logsdon John M., Jr., Ragan Mark A., Hirt Robert P., and Roger Andrew J., „A Genomic Survey of the Fish Parasite Spironucleus salmonicida Indicates Genomic Plasticity Among Diplomonads and Significant Lateral Gene Transfer in Eukaryote Genome Evolution”, BMC Genomics 2007, vol. 8, no. 51.

Andolfatto Peter, „Adaptive Evolution of Non-Coding DNA in Drosophila”, Nature 2005, vol. 437, s. 1149-1152.

Angly Florent E., Felts Ben, Breitbart Mya, Salamon Peter, Edwards Robert A., Carlson Craig, Chan Amy M., Haynes Matthew, Kelley Scott, Liu Hong et al., „The Marine Viromes of Four Oceanic Regions", PLoS Biology 2006, vol. 4, e368.

Aravind L., Tatusov Roman L., Wolf Yuri I., Walker D.R., and Koonin Eugene V., „Evidence for Massive Gene Exchange Between Archaeal and Bacterial Hyperthermophiles", Trends in Genetics 1998, vol. 14, s. 442-444.

Argos Patrick, Kamer Gregory, Nicklin Martin J., and Wimmer Eckard, „Similarity in Gene Organization and Homology Between Proteins of Animal Picornaviruses and a Plant Comovirus Suggest Common Ancestry of These Virus Families", Nucleic Acids Research 1984, vol. 12, s. 7251-7267. 
Artamonova Irena I. and Gelfand Mikhail S., „Comparative Genomics and Evolution of Alternative Splicing: The Pessimists' Science”, Chemical Review 2007, vol. 107, s. $3407-$ 3430 .

Bapteste Eric, Susko Edward, Leigh Jessica W., MacLeod Dave, Charlebois Robert L., and Doolittle W. Ford, „Do Orthologous Gene Phylogenies Really Support Tree-Thinking?”, BMC Evolutionary Biology 2005, vol. 5, no. 33.

Bejerano Gill, Pheasant Michael, Makunin Igor, Stephen Stuart, Kent W. James, Mattick John S., and Haussler David, „Ultraconserved Elements in the Human Genome”, Science 2004, vol. 304, s. 1321-1325.

Black Douglas L., „Mechanisms of Alternative Pre-Messenger RNA Splicing”, Annual Review of Biochemistry 2003, vol. 72, s. 291-336.

Brochier Corinne, Philippe Hene', and de Melo Moreira Débora Regina, „The Evolutionary History of Ribosomal Protein RpS14: Horizontal Gene Transfer at the Heart of the Ribosome", Trends in Genetics 2000, vol. 16, s. 529-533.

Brown James R., „Genomic and Phylogenetic Perspectives on the Evolution of Prokaryotes", Systematic Biology 2001, vol. 50, s. 497-512.

Browne Janet, „Birthdays to Remember”, Nature 2008, vol. 456, s. 324-325.

Bryson Vernon and Vogel Henry (eds.), Evolving Gene and Proteins, Academic Press, New York 1965.

Bürglin Thomas R., „Evolution of Hedgehog and Hedgehog-Related Genes, Their Origin from Hog Proteins in Ancestral Eukaryotes and Discovery of a Novel Hint Motif", BMC Genomics 2008, vol. 9, no. 127.

Bushman Frederic, Lateral DNA Transfer: Mechanisms and Consequences, Cold Spring Harbor Laboratory Press, Cold Spring Harbor, New York 2001.

Cairns John, Stent Gunther S., and Watson James D. (eds.), Phage and the Origins of Molecular Biology, CSHL Press, Cold Spring Harbor, New York 1966.

Carlton Jane M., Hirt Robert P., Silva Joana C., Delcher Arthur L., Schatz Michael, Zhao Qi, Wortman Jennifer R., Bidwell Shelby L., Alsmark U. Cecilia M., Besteiro Sébastien et al., „Draft Genome Sequence of the Sexually Transmitted Pathogen Trichomonas vaginalis", Science 2007, vol. 315, s. 207-212.

Carmel Liran, Wolf Yuri I., Rogozin Igor B., and Koonin Eugene V., „Three Distinct Modes of Intron Dynamics in the Evolution of Eukaryotes”, Genome Research 2007, vol. 17, s. $1034-1044$

Castillo-Davis Cristian I., Kondrashov Fyodor A., Hartl Daniel L., and Kulathinal Rob J., ,The Functional Genomic Distribution of Protein Divergence in Two Animal Phyla: Coevolution, Genomic Conflict, and Constraint", Genome Research 2004, vol. 14, s. 802-811. 
Charlebois Robert L. and Doolittle W. Ford, „Computing Prokaryotic Gene Ubiquity: Rescuing the Core from Extinction”, Genome Research 2004, vol. 14, s. 2469-2477.

Chen John Xi and Novick Richard P., „Phage-Mediated Intergeneric Transfer of Toxin Genes", Science 2009, vol. 323, s. 139-141.

Clark Andrew G., Eisen Michael B., Smith Douglas R., Bergman Casey M., Oliver Brian, Markow Therese A., Kaufman Thomas C., Kellis Manolis, Gelbart William, Iyer Venky N. et al., „Evolution of Genes and Genomes on the Drosophila Phylogeny”, Nature 2007, vol. 450 , s. 203-218.

Conant Gavin C. and Wolfe Kenneth H., „Turning a Hobby into a Job: How Duplicated Genes Find New Functions", Nature Reviews Genetics 2008, vol. 9, s. 938-950.

Crick Francis H., „On Protein Synthesis”, Symposia of the Society for Experimental Biology 1958, vol. 12, s. 138-163.

CsűrÖs Miklós, Rogozin Igor B., and Koonin Eugene V., „Extremely Intron-Rich Genes in the Alveolate Ancestors Inferred with a Flexible Maximum-Likelihood Approach", Molecular Biology and Evolution 2008, vol. 25, s. 903-911.

CutLer David J., „Understanding the Overdispersed Molecular Clock”, Genetics 2000, vol. 154, s. 1403-1417.

Dagan Tal and Martin William F., „Testing Hypotheses Without Considering Predictions”, BioEssays 2007, vol. 29, s. 500-503.

Dagan Tal and Martin William F., „The Tree of One Percent”, Genome Biology 2006, vol. 7 , no. 118 .

DARwin Charles, „On the Tendency of Species to Form Varieties; And on the Perpetuation of Varieties and Species by Natural Means of Selection. I. Extract from an Unpublished Work on Species, II. Abstract of a Letter from C. Darwin, esq., to Prof. Asa Gray”, Journal of the Proceedings of the Linnean Society of London 1858, vol. 3, s. 45-53.

DARWIN Karol, O powstawaniu gatunków drogą doboru naturalnego, czyli o utrzymaniu się doskonalszych ras w walce o byt, tekst polski na podstawie przekładu Szymona Dicksteina i Józefa Nusbauma opracowały Joanna Popiołek i Małgorzata Yamazaki, Wydawnictwa Uniwersytetu Warszawskiego, Warszawa 2009.

Dawkins Richard, Samolubny gen, przeł. Marek Skoneczny, Na Ścieżkach Nauki, Prószyński i S-ka, Warszawa 1996.

DAYhoff Margaret O., BARKer Winona C., and Hunt Lois T., „Establishing Homologies in Protein Sequences”, Methods in Enzymology 1983, vol. 91, s. 524-545.

Dayhoff Margaret O., Barker Winona C., and McLaughlin Patrick J., „Inferences from Protein and Nucleic Acid Sequences: Early Molecular Evolution, Divergence of Kingdoms and Rates of Change", Origins of Life 1974, vol. 5, s. 311-330. 
De Koning Anoek P., Brinkman Fiona S.L., Jones Steven J.M., and Keeling Patrick J., „Lateral Gene Transfer and Metabolic Adaptation in the Human Parasite Trichomonas vaginalis", Molecular Biology and Evolution 2000, vol. 17, s. 1769-1773.

DE Lamarck Jean-Baptiste, Filozofia zoologii, przeł. Krystyna Zaćwilichowska, Polskie Wydawnictwo Naukowe, Warszawa 1960.

Dehal Paramvir and Boore Jeffrey L., „Two Rounds of Whole Genome Duplication in the Ancestral Vertebrate", PLoS Biology 2005, vol. 3, e314.

DeLong Edward F. and Karl David M., „Genomic Perspectives in Microbial Oceanography", Nature 2005, vol. 437, s. 336-342.

Delwart Eric L., „Viral Metagenomics”, Reviews in Medical Virology 2007, vol. 17, s. 115-131.

Dobzhansky Theodosius, Genetics and the Origin of Species, Columbia University Press, New York 1937.

Doolittle W. Ford, „Phylogenetic Classification and the Universal Tree”, Science 1999, vol. 284, s. 2124-2129.

Doolittle W. Ford and BAPteste Eric, „Pattern Pluralism and the Tree of Life Hypothesis”, Proceedings of the National Academy of Sciences USA 2007, vol. 104, s. 2043-2049.

Doolittle W. Ford and SaPienza Carmen, „Selfish Genes, the Phenotype Paradigm and Genome Evolution", Nature 1980, vol. 284, s. 601-603.

Drummond D. Allan, Bloom Jesse D., Adami Christoph, Wilke Claus O., and Arnold Frances H., „Why Highly Expressed Proteins Evolve Slowly”, Proceedings of the National Academy of Sciences USA 2005, vol. 102, s. 14338-14343.

Drummond D. Allan, Raval Alpan, and Wilke Claus O., „A Single Determinant Dominates the Rate of Yeast Protein Evolution", Molecular Biology and Evolution 2006, vol. 23, s. 327-337.

Drummond D. Allan and WiLke Claus O., „Mistranslation-Induced Protein Misfolding as a Dominant Constraint on Coding-Sequence Evolution”, Cell 2008, vol. 134, s. 341-352.

Dunning Hotopp Julie C., Clark Michael E., Oliveira Deodoro C.S.G., Foster Jeremy M., Fischer Peter, Muñoz Torres Mónica C., Giebel Jonathan D., Kumar Nikhil, Ishmael Nadeeza, WANG Shiliang et al., „Widespread Lateral Gene Transfer from Intracellular Bacteria to Multicellular Eukaryotes", Science 2007, vol. 317, s. 1753-1756.

Durand Dannie, „Vertebrate Evolution: Doubling and Shuffling with a Full Deck”, Trends in Genetics 2003, vol. 19, s. 2-5.

Eck Richard V. and DAYHofF Margaret O., „Evolution of the Structure of Ferredoxin Based on Living Relics of Primitive Amino Acid Sequences", Science 1966, vol. 152, s. 363-366. 
Edwards Robert A. and Rohwer Forest, „Viral Metagenomics”, Nature Reviews Microbiology 2005, vol. 3, s. 504-510.

EISEN Jonathan A. and Fraser Claire M., „Phylogenomics: Intersection of Evolution and Genomics”, Science 2003, vol. 300, s. 1706-1707.

Eisen Jonathan A., Heidelberg John F., White Owen, and SAlzberg Steven L., „Evidence for Symmetric Chromosomal Inversions Around the Replication Origin in Bacteria", Genome Biology 2000, vol. 1, RESEARCH0011.

EMBLEY T. Martin, „Multiple Secondary Origins of the Anaerobic Lifestyle in Eukaryotes”, Philosophical Transactions of the Royal Society of London B: Biological Sciences 2006, vol. 361, s. 1055-1067.

EMBLEy T. Martin and Martin William, „Eukaryotic Evolution, Changes and Challenges”, Nature 2006, vol. 440, s. 623-630.

Esser Christian, Ahmadinejad Nahal, Wiegand Christian, Rotte Carmen, Sebastiani Federico L., Gelius-Dietrich Gabriel, Henze Katrin, Kretschmann Ernst, Richly Erik, Leister Dario et al., „A Genome Phylogeny for Mitochondria Among Alpha-Proteobacteria and a Predominantly Eubacterial Ancestry of Yeast Nuclear Genes", Molecular Biology and Evolution 2004, vol. 21, s. 1643-1660.

Esser Christian, Martin William, and Dagan Tal, ,The Origin of Mitochondria in Light of a Fluid Prokaryotic Chromosome Model”, Biology Letters 2007, vol. 3, s. 180-184.

Fedorov Alexei, Merican Amir F., and Gilbert Walter, „Largescale Comparison of Intron Positions Among Animal, Plant, and Fungal Genes", Proceedings of the National Academy of Sciences USA 2002, vol. 99, s. 16128-16133.

FINNEGAN David J., „Transposable Elements in Eukaryotes”, International Review of Cytology 1985, vol. 93, s. 281-326.

FISHER Ronald A., The Genetical Theory of Natural Selection, Clarendon Press, Oxford 1930.

FIsHer Ronald A., „The Possible Modification of the Response of the Wild Type to Recurrent Mutations", The American Naturalist 1928, vol. 62, s. 115-126.

ForTerre Patrick, „The Origin of Viruses and Their Possible Roles in Major Evolutionary Transitions", Virus Research 2006, vol. 117, s. 5-16.

Fraser Claire M., Eisen Jonathan A., and Salzberg Steven L., „Microbial Genome Sequencing", Nature 2000, vol. 406, s. 799-803.

FreELING Michael, „The Evolutionary Position of Subfunctionalization, Downgraded”, Genome Dynamics 2008, vol. 4, s. 25-40. 
Frost Laura S., Leplae Raphael, Summers Anne O., and Toussaint Ariane, „Mobile Genetic Elements: The Agents of Open Source Evolution", Nature Reviews Microbiology 2005, vol. 3, s. 722-732.

Futuyma Douglas J., Ewolucja, przekł. pod red. Jacka Radwana, Wydawnictwa Uniwersytetu Warszawskiego, Warszawa 2008.

Georgiev Georgii P., „Mobile Genetic Elements in Animal Cells and Their Biological Significance”, European Journal of Biochemistry 1984, vol. 145, s. 203-220.

Georgiev Georgii P., Ilyin Y.V., Ryskov A.P., Tchurikov Nickolai A., Yenikolopov Grigori N., Gvozdev Vladimir A., and Ananiev E.V., „Isolation of Eukaryotic DNA Fragments Containing Structural Genes and the Adjacent Sequences", Science 1977, vol. 195, s. $394-$ 397.

GlansdorfF Nicholas, Xu Ying, and Labedan Bernard, „The Last Universal Common Ancestor: Emergence, Constitution and Genetic Legacy of an Elusive Forerunner", Biology Direct 2008, vol. 3, no. 29.

Glazko Galina V., Koonin Eugene V., Rogozin Igor B., and Shabalina Svetlana A., „A Significant Fraction of Conserved Noncoding DNA in Human and Mouse Consists of Predicted Matrix Attachment Regions", Trends in Genetics 2003, vol. 19, s. 119-124.

Glazko Galina V., Makarenkov Vladimir, Liu Jing, and Mushegian Arcady, „Evolutionary History of Bacteriophages with Double-Stranded DNA Genomes”, Biology Direct 2007, vol. 2 , no. 36 .

Gogarten J. Peter, Doolittle W. Ford, and Lawrence Jeffrey G., „Prokaryotic Evolution in Light of Gene Transfer”, Molecular Biology and Evolution 2002, vol. 19, s. 2226-2238.

Gogarten J. Peter and Townsend Jeffrey P., „Horizontal Gene Transfer, Genome Innovation and Evolution”, Nature Reviews Microbiology 2005, vol. 3, s. 679-687.

GoldBach Rob, „Genome Similarities Between Plant and Animal RNA Viruses”, Microbiological Sciences 1987, vol. 4, s. 197-202.

Goodier John L. and KazAZIAN Haig H., Jr., „,Retrotransposons Revisited: The Restraint and Rehabilitation of Parasites", Cell 2008, vol. 135, s. 23-35.

Gould Stephen Jay, Full House: The Spread of Excellence from Plato to Darwin, Three Rivers Press, New York 1997.

Gould Stephen Jay, „The Exaptive Excellence of Spandrels as a Term and Prototype”, Proceedings of the National Academy of Sciences USA 1997, vol. 94, s. 10750-10755.

Gould Stephen Jay, The Structure of Evolutionary Theory, Harvard University Press, Cambridge, Massachusetts 2002. 
Gould Stephen Jay and Lewontin Richard C., „The Spandrels of San Marco and the Panglossian Paradigm: A Critique of the Adaptationist Programme", Proceedings of the Royal Society of London B: Biological Sciences 1979, vol. 205, s. 581-598.

GRAY Michael W., „The Endosymbiont Hypothesis Revisited”, International Review of Cytology 1992, vol. 141, s. 233-357.

Gray Michael W., Burger Gertraud, and Lang B. Franz, „The Origin and Early Evolution of Mitochondria", Genome Biology 2001, vol. 2, no. 6.

Grishin Nick V., Wolf Yuri I., and Koonis Eugene V., „From Complete Genomes to Measures of Substitution Rate Variability Within and Between Proteins", Genome Research 2000, vol. 10, s. 991-1000.

HACKER Jörg H. and KAPER James B., „Pathogenicity Islands and the Evolution of Microbes”, Annual Review of Microbiology 2000, vol. 54, s. 641-679.

Haddrill Penelope R., Bachtrog Doris, and Andolfatto Peter, „Positive and Negative Selection on Noncoding DNA in Drosophila simulans", Molecular Biology and Evolution 2008, vol. 25, s. 1825-1834.

HAECKEL Ernst, The Wonders of Life: A Popular Study of Biological Philosophy, Watts \& Co., London 1904.

Haldane John B.S., The Causes of Evolution, Longmans, Green \& Co., London 1932.

Hall Tracy M., Porter Jeffery A., Young Keith E., Koonin Eugene V., Beachy Philip A., and LeaHY Daniel J., „Crystal Structure of a Hedgehog Autoprocessing Domain: Homology Between Hedgehog and Self-Splicing Proteins", Cell 1997, vol. 91, s. 85-97.

Halligan Daniel L. and Keightley Peter D., „Ubiquitous Selective Constraints in the Drosophila Genome Revealed by a Genome-Wide Interspecies Comparison", Genome Research 2006, vol. 16, s. 875-884.

Harris J. Kirk, Kelley Scott T., SPiegelman George B., and Pace Norman R., „The Genetic Core of the Universal Ancestor", Genome Research 2003, vol. 13, s. 407-412.

HartL Daniel L., „Molecular Melodies in High and Low C”, Nature Reviews Genetics 2000, vol. 1, s. 145-149.

He Xionglei and Zhang Jianzhi, „Rapid Subfunctionalization Accompanied by Prolonged and Substantial Neofunctionalization in Duplicate Gene Evolution", Genetics 2005, vol. 169 , s. 1157-1164.

Hillenmeyer Maureen E., Fung Eula, Wildenhain Jan, Pierce Sarah E., Hoon Shawn, Lee William, Proctor Michael, Onge Robert P. St., Tyers Mike, Koller Daphne et al., „The Chemical Genomic Portrait of Yeast: Uncovering a Phenotype for All Genes", Science 2008, vol. 320, s. 362-365. 
Hirsh Aaron E. and Fraser Hunter B., „Protein Dispensability and Rate of Evolution”, $\mathrm{Na}$ ture 2001, vol. 411, s. 1046-1049.

Hoegg Simone and Meyer Axel, „Hox Clusters as Models for Vertebrate Genome Evolution", Trends in Genetics 2005, vol. 21, s. 421-424.

Hurst Laurence D., PÁl Csaba, and Lercher Martin J., „The Evolutionary Dynamics of Eukaryotic Gene Order", Nature Reviews Genetics 2004, vol. 5, s. 299-310.

Hurst Laurence D. and Smith Nick G.C., „Do Essential Genes Evolve Slowly?”, Current Biology 1999, vol. 9, s. 747-750.

Huxley Julian S., Evolution: The Modern Synthesis, Allen and Unwin, London 1942.

Huynen Martijn A. and van Nimwegen Erik, „The Frequency Distribution of Gene Family Sizes in Complete Genomes”, Molecular Biology and Evolution 1998, vol. 15, s. 583-589.

Irimia Manuel, Penny David, and Roy Scott W., „Coevolution of Genomic Intron Number and Splice Sites", Trends in Genetics 2007, vol. 23, s. 321-325.

Iтон Takeshi, Такемото Keiko, Mori Hirotada, and Gojobori Takashi, „Evolutionary Instability of Operon Structures Disclosed by Sequence Comparisons of Complete Microbial Genomes", Molecular Biology and Evolution 1999, vol. 16, s. 332-346.

Iyer Lakshminarayan M., BalajI Sandhiya, Koonin Eugene V., and Aravind L., „Evolutionary Genomics of Nucleo-Cytoplasmic Large DNA Viruses”, Virus Research 2006, vol. 117 , s. $156-184$.

IYer Lakshminarayan M., KoONIn Eugene V., and ArAvind L., „Evolution of Bacterial RNA Polymerase: Implications for Large-Scale Bacterial Phylogeny, Domain Accretion, and Horizontal Gene Transfer", Gene 2004, vol. 335, s. 73-88.

Iyer Lakshminarayan M., MaKarova Kira S., Koonin Eugene V., and Aravind L., „Comparative Genomics of the FtsK-HerA Superfamily of Pumping ATPases: Implications for the Origins of Chromosome Segregation, Cell Division and Viral Capsid Packaging", $\mathrm{Nu}$ cleic Acids Research 2004, vol. 32, s. 5260-5279.

JАСов François, „Evolution and Tinkering”, Science 1977, vol. 196, s. 1161-1166.

JAILlon Olivier, Bouhouche Khaled, Gout Jean-François, Aury Jean-Marc, Noel Benjamin, Saudemont Baptiste, Nowacki Mariusz, Serrano Vincent, Porcel Betina M., Ségurens Béatrice et al., „Translational Control of Intron Splicing in Eukaryotes”, Nature 2008, vol. 451, s. 359-362.

JAIN Ravi, Rivera Maria C., and LaKe James A., „Horizontal Gene Transfer Among Genomes: The Complexity Hypothesis", Proceedings of the National Academy of Sciences USA 1999, vol. 96, s. 3801-3806. 
Jordan I. King, Mariño-Ramírez Leonardo, and Koonin Eugene V., „Evolutionary Significance of Gene Expression Divergence”, Gene 2005, vol. 345, s. 119-126.

Jordan I. King, Mariño-Ramírez Leonardo, Wolf Yuri I., and Koonin Eugene V., „Conservation and Coevolution in the Scale-Free Human Gene Coexpression Network", Molecular Biology and Evolution 2004, vol. 21, s. 2058-2070.

JoRdan I. King, Rogozin Igor B., Glazko Galina V., and Koonin Eugene V., „Origin of a Substantial Fraction of Human Regulatory Sequences from Transposable Elements", Trends in Genetics 2003, vol. 19, s. 68-72.

Jordan I. King, Rogozin Igor B., Wolf Yuri I., and Koonin Eugene V., „Essential Genes Are More Evolutionarily Conserved Than Are Nonessential Genes in Bacteria”, Genome Research 2002, vol. 12, s. 962-968.

Jordan I. King, Rogozin Igor B., Wolf Yuri I., and Koonin Eugene V., „Microevolutionary Genomics of Bacteria”, Theoretical Population Biology 2002, vol. 61, s. 435-447.

Kamer Gregory and Argos Patrick, „Primary Structural Comparison of RNA-Dependent Polymerases from Plant, Animal and Bacterial Viruses”, Nucleic Acids Research 1984, vol. 12, s. 7269-7282.

Karev Georgy P., Wolf Yuri I., Rzhetsky Andrey Y., Berezovskaya Faina S., and Koonin Eugene V., „Birth and Death of Protein Domains: A Simple Model of Evolution Explains Power Law Behavior", BMC Evolutionary Biology 2002, vol. 2, no. 18.

Karl David M., „Microbial Oceanography: Paradigms, Processes and Promise”, Nature Reviews Microbiology 2007, vol. 5, s. 759-769.

Kasha Michael and Pullman Bernard (eds.), Horizons in Biochemistry, Academic Press, New York 1962.

Katzman Sol, Kern Andrew D., Bejerano Gill, Fewell Ginger, Fulton Lucinda, Wilson Richard K., Salama Sofie R., and Haussler David, „Human Genome Ultraconserved Elements Are Ultraselected", Science 2007, vol. 317, s. 915.

Kelley Lawrence L. and Scott Michael, „The Evolution of Biology: A Shift Towards the Engineering of Prediction-Generating Tools and Away from Traditional Research Practice", EMBO Reports 2008, vol. 9, s. 1163-1167.

Khaitovich Philipp, Enard Wolfgang, Lachmann Michael, and PäÄвo Svante, „Evolution of Primate Gene Expression", Nature Reviews Genetics 2006, vol. 7, s. 693-702.

Kimura Motoo, „Evolutionary Rate at the Molecular Level”, Nature 1968, vol. 217, s. 624626.

Kimura Motoo, „Recent Development of the Neutral Theory Viewed from the Wrightian Tradition of Theoretical Population Genetics", Proceedings of the National Academy of Sciences USA 1991, vol. 88, s. 5969-5973. 
Kimura Mooto, The Neutral Theory of Molecular Evolution, Cambridge University Press, Cambridge 1983.

King Jack L. and JukEs Thomas H., „Non-Darwinian Evolution”, Science 1969, vol. 164, s. 788-798.

Kondrashov Fyodor A. and Koonin Eugene V., „Evolution of Alternative Splicing: Deletions, Insertions and Origin of Functional Parts of Proteins from Intron Sequences", Trends in Genetics 2003, vol. 19, s. 115-119.

Kondrashov Fyodor A., Koonin Eugene V., Morgunov Igor G., Finogenova Tatiana V., and Kondrashova Marie N., „Evolution of Glyoxylate Cycle Enzymes in Metazoa: Evidence of Multiple Horizontal Transfer Events and Pseudogene Formation", Biology Direct 2006, vol. 1 , no. 31

Kondrashov Fyodor A., Rogozin Igor B., Wolf Yuri I., and Koonin Eugene V., ,Selection in the Evolution of Gene Duplications", Genome Biology 2002, vol. 3, RESEARCH0008.

Koonin Eugene V., „A Non-Adaptationist Perspective on Evolution of Genomic Complexity Or the Continued Dethroning of Man”, Cell Cycle 2004, vol. 3, s. 280-285.

Koonin Eugene V., „Comparative Genomics, Minimal Gene-Sets and the Last Universal Common Ancestor", Nature Reviews Microbiology 2003, vol. 1, s. 127-136.

Koonin Eugene V., „Evolution of Genome Architecture”, The International Journal of Biochemistry and Cell Biology 2009, vol. 41, s. 298-306.

Koonin Eugene V., „Horizontal Gene Transfer: The Path to Maturity”, Molecular Microbiology 2003, vol. 50, s. 725-727.

Koonin Eugene V., „On the Origin of Cells and Viruses: Primordial Virus World Scenario", Annals of the New York Academy of Sciences 2009, vol. 1178, s. 47-64.

Koonin Eugene V., „The Biological Big Bang Model for the Major Transitions in Evolution", Biology Direct 2007, vol. 2, no. 21.

Koonin Eugene V. and Dolja Valerian V., „Evolution and Taxonomy of Positive-Strand RNA Viruses: Implications of Comparative Analysis of Amino Acid Sequences", Critical Reviews in Biochemistry and Molecular Biology 1993, vol. 28, s. 375-430.

Koonin Eugene V., Fedorova Natalie D., Jackson John D., Jacobs Aviva R., Krylov Dmitri M., Makarova Kira S., Mazumder Raja, Mekhedov Sergei L., Nikolskaya Anastasia N., RAO B. Sridhar et al., „A Comprehensive Evolutionary Classification of Proteins Encoded in Complete Eukaryotic Genomes", Genome Biology 2004, vol. 5, s. R7.

Koonin Eugene V. and Martin William, „On the Origin of Genomes and Cells Within Inorganic Compartments", Trends in Genetics 2005, vol. 21, s. 647-654. 
Koonin Eugene V. and Mushegian Arcady R., „Complete Genome Sequences of Cellular Life Forms: Glimpses of Theoretical Evolutionary Genomics", Current Opinion in Genetics and Development 1996, vol. 6, s. 757-762.

Koonin Eugene V., Mushegian Arcady R., and Rudd Kenneth E., „Sequencing and Analysis of Bacterial Genomes", Current Biology 1996, vol. 6, s. 404-416.

Koonin Eugene V., Senkevich Tatiana G., and Dolja Valerian V., „The Ancient Virus World and Evolution of Cells", Biology Direct 2006, vol. 1, no. 29.

Koonin Eugene V. and Wolf Yuri I., „Evolutionary Systems Biology”, w: PAGel and PoMIANKOWSKI, (eds.), Evolutionary Genomics..., s. 11-25.

Koonin Eugene V. and Wolf Yuri I., „Evolutionary Systems Biology: Links Between Gene Evolution and Function", Current Opinion in Biotechnology 2006, vol. 17, s. 481-487.

Koonin Eugene V. and Wolf Yuri I., „Genomics of Bacteria and Archaea: The Emerging Dynamic View of the Prokaryotic World", Nucleic Acids Research 2008, vol. 36, s. 66886719.

Koonin Eugene V. and Wolf Yuri I., „Genomics of Bacteria and Archaea: The Emerging Generalizations After 13 Years", Nucleic Acids Research 2008, vol. 36, s. 6688-6719.

Koonin Eugene V., Wolf Yuri I., and Karev Georgy P. (eds.), Power Laws, Scale-Free Networks and Genome Biology, Landes Bioscience, Georgetown, Texas 2006.

Koonin Eugene V., Wolf Yuri I., and Karev Georgy P., „,The Structure of the Protein Universe and Genome Evolution”, Nature 2002, vol. 420, s. 218-223.

Koonin Eugene V., Wolf Yuri I., Nagasaki Keizo, and Dolja Valerian V., „The Big Bang of Picorna-Like Virus Evolution Antedates the Radiation of Eukaryotic Supergroups", $\mathrm{Na}$ ture Reviews Microbiology 2008, vol. 6, s. 925-939.

Kosiol Carolin, Vinař Tomáš, da Fonseca Rute R., Hubisz Melissa J., Bustamante Carlos D., Nielsen Rasmus, and SiePel Adam, „Patterns of Positive Selection in Six Mammalian Genomes", PLoS Genetics 2008, vol. 4, e1000144.

Kreitman Martin, „Methods to Detect Selection in Populations with Applications to the Human", Annual Review of Genomics and Human Genetics 2000, vol. 1, s. 539-559.

Krylov Dmitri M., Wolf Yuri I., Rogozin Igor B., and Koonin Eugene V., „Gene Loss, Protein Sequence Divergence, Gene Dispensability, Expression Level, and Interactivity Are Correlated in Eukaryotic Evolution", Genome Research 2003, vol. 13, s. 2229-2235.

Kunin Victor and Ouzounis Christos A., „The Balance of Driving Forces During Genome Evolution in Prokaryotes", Genome Research 2003, vol. 13, s. 1589-1594. 
Kurland Charles G., CAnBäck Björn, and Berg Otto G., „Horizontal Gene Transfer: A Critical View", Proceedings of the National Academy of Sciences USA 2003, vol. 100, s. 96589662.

Kurland Charles G., Coluins Laura J., and Penny David, „Genomics and the Irreducible Nature of Eukaryote Cells”, Science 2006, vol. 312, s. 1011-1014.

Langer Martin, Gabor Esther M., Liebeton Klaus, Meurer Guido, Niehaus Frank, Schulze Renate, Eck Jürgen, and Lorenz Patrick, „Metagenomics: An Inexhaustible Access to Nature's Diversity”, Biotechnology Journal 2006, vol. 1, s. 815-821.

Lawrence Jeffrey G., „Gene Organization: Selection, Selfishness, and Serendipity”, Annual Review of Microbiology 2003, vol. 57, s. 419-440.

Lawrence Jeffrey G., „Selfish Operons and Speciation by Gene Transfer”, Trends in Microbiology 1997, vol. 5, s. 355-359.

Lawrence Jeffrey G., „Selfish Operons: The Evolutionary Impact of Gene Clustering in Prokaryotes and Eukaryotes", Current Opinion in Genetics and Development 1999, vol. 9, s. $642-648$.

Lawrence Jeffrey G. and Hendrickson Heather L., „Lateral Gene Transfer: When Will Adolescence End?", Molecular Microbiology 2003, vol. 50, s. 739-749.

Lazcano Antonio and Forterre Patrick, „The Molecular Search for the Last Common Ancestor", Journal of Molecular Evolution 1999, vol. 49, s. 411-412.

Leipe Detlef D., Aravind L., and Koonin Eugene V., „Did DNA Replication Evolve Twice Independently?", Nucleic Acids Research 1999, vol. 27, s. 3389-3401.

LiAo Ben-Yang and ZHANG Jianzhi, „Evolutionary Conservation of Expression Profiles Between Human and Mouse Orthologous Genes", Molecular Biology and Evolution 2006, vol. 23, s. 530-540.

Liao Ben-Yang and Zhang Jianzhi, „Low Rates of Expression Profile Divergence in Highly Expressed Genes and Tissue-Specific Genes During Mammalian Evolution”, Molecular Biology and Evolution 2006, vol. 23, s. 1119-1128.

Linnemann Amelia K., Platts Adrian E., and Krawetz Stephen A., „Differential Nuclear Scaffold/Matrix Attachment Marks Expressed Genes”, Human Molecular Genetics 2009, vol. 18, s. 645-654.

Liolios Konstantinos, Mavromatis Konstantinos, Tavernarakis Nektarios, and Kyrpides Nikos C., „The Genomes On Line Database (GOLD) in 2007: Status of Genomic and Metagenomic Projects and Their Associated Metadata", Nucleic Acids Research 2008, vol. 36, s. D475-D479. 
Long Manyuan, Betrán Esther, Thornton Kevin, and Wang Wen, „The Origin of New Genes: Glimpses from the Young and Old”, Nature Reviews Genetics 2003, vol. 4, s. 865875 .

Lunter Gerton, Ponting Chris P., and Hein Jotun, „Genome-Wide Identification of Human Functional DNA Using a Neutral Indel Model”, PLoS Computational Biology 2006, vol. 2, e5.

Lynch Michael, „The Frailty of Adaptive Hypotheses for the Origins of Organismal Complexity", Proceedings of the National Academy of Sciences USA 2007, vol. 104, suppl. 1, s. 8597-8604.

Lynch Michael, The Origins of Genome Architecture, Sinauer Associates, Sunderland, Massachusetts 2007.

Lynch Michael and Conery John S., „The Evolutionary Fate and Consequences of Duplicate Genes", Science 2000, vol. 290, s. 1151-1155.

Lynch Michael and Conery John S., „The Origins of Genome Complexity”, Science 2003, vol. 302, s. 1401-1404.

Lynch Michael and Force Allan, „The Probability of Duplicate Gene Preservation by Subfunctionalization", Genetics 2000, vol. 154, s. 459-473.

Lynch Michael and Katu Vaishali, „The Altered Evolutionary Trajectories of Gene Duplicates", Trends in Genetics 2004, vol. 20, s. 544-549.

Lynch Michael and Kewalramani Avinash, „Messenger RNA Surveillance and the Evolutionary Proliferation of Introns", Molecular Biology and Evolution 2003, vol. 20, s. 563571.

Lyons Sherrie L., Thomas Henry Huxley: The Evolution of a Scientist, Prometheus, Amherst - New York 2000.

MakaŁowski Wojciech and Boguski Mark S., „Evolutionary Parameters of the Transcribed Mammalian Genome: An Analysis of 2,820 Orthologous Rodent and Human Sequences", Proceedings of the National Academy of Sciences USA 1998, vol. 95, s. 9407-9412.

Makarova Kira S., Ponomarev V.A., and Koonin Eugene V., „Two C Or Not Two C: Recurrent Disruption of Zn-Ribbons, Gene Duplication, Lineage-Specific Gene Loss, and Horizontal Gene Transfer in Evolution of Bacterial Ribosomal Proteins", Genome Biology 2001, vol. 2, RESEARCH0033.

Makarova Kira S., Slesarev Alexei I., Wolf Yuri I., Sorokin Alexander V., Mirkin Boris G., Koonin Eugene V., Pavlov Andrey, Pavlova N., Karamychev V., Polouchine N. et al., „Comparative Genomics of the Lactic Acid Bacteria", Proceedings of the National Academy of Sciences USA 2006, vol. 103, s. 15611-15616. 
Makarova Kira S., Sorokin Alexander V., Novichkov Pavel S., Wolf Yuri I., and Koonin Eugene V., „Clusters of Orthologous Genes for 41 Archaeal Genomes and Implications for Evolutionary Genomics of Archaea”, Biology Direct 2007, vol. 2, no. 33.

Makarova Kira S., Wolf Yuri I., Mekhedov Sergey L., Mirkin Boris G., and Koonin Eugene V., „Ancestral Paralogs and Pseudoparalogs and Their Role in the Emergence of the Eukaryotic Cell”, Nucleic Acids Research 2005, vol. 33, s. 4626-4638.

Martin Whitney, Hoffmeister Meike, Rotte Carmen, and Henze Katrin, „An Overview of Endosymbiotic Models for the Origins of Eukaryotes, Their ATP-Producing Organelles (Mitochondria and Hydrogenosomes), and Their Heterotrophic Lifestyle", Biological Chemistry 2001, vol. 382, s. 1521-1539.

Martin William and Koonin Eugene V., „Introns and the Origin of Nucleus-Cytosol Compartmentation", Nature 2006, vol. 440, s. 41-45.

Martin William and Müller Miklós, „The Hydrogen Hypothesis for the First Eukaryote”, Nature 1998, vol. 392, s. 37-41.

Martin William, Rujan Tamas, Richly Erik, Hansen Andrea, Cornelsen Sabine, Lins Thomas, Leister Dario, Stoebe Bettina, Hasegawa Masami, and Penny David, „Evolutionary Analysis of Arabidopsis, Cyanobacterial, and Chloroplast Genomes Reveals Plastid Phylogeny and Thousands of Cyanobacterial Genes in the Nucleus", Proceedings of the National Academy of Sciences USA 2002, vol. 99, s. 12246-12251.

Martin William and Russell Michael J., „On the Origins of Cells: A Hypothesis for the Evolutionary Transitions from Abiotic Geochemistry to Chemoautotrophic Prokaryotes, and from Prokaryotes to Nucleated Cells", Philosophical Transactions of the Royal Society of London B: Biological Sciences 2003, vol. 358, s. 59-83.

MaYr Ernst, Systematics and the Origin of Species, Columbia University Press, New York 1944.

MAYr Ernst, „The Emergence of Evolutionary Novelties”, w: TAX (ed.), The Evolution of Life..., s. 349-380.

McCuntock Barbara, „The Origin and Behavior of Mutable Loci in Maize”, Proceedings of the National Academy of Sciences USA 1950, vol. 36, s. 344-355.

McGeoch Adam T. and Bell Stephen D., „Extra-Chromosomal Elements and the Evolution of Cellular DNA Replication Machineries”, Nature Reviews Molecular Cell Biology 2008, vol. 9, s. 569-574.

McInerney James O., „The Causes of Protein Evolutionary Rate Variation”, Trends in Ecology and Evolution 2006, vol. 21, s. 230-232.

McLysaght Aoife, Hokamp Karsten, and Wolfe Kenneth H., „Extensive Genomic Duplication During Early Chordate Evolution”, Nature Genetics 2002, vol. 31, s. 200-204. 
Medina Mónica, „Genomes, Phylogeny, and Evolutionary Systems Biology”, Proceedings of the National Academy of Sciences USA 2005, vol. 102, suppl. 1, s. 6630-6635.

Mendell Jennifer E., Clements Kendall D., ChoAt J. Howard, and Angert Esther R., „Extreme Polyploidy in a Large Bacterium", Proceedings of the National Academy of Sciences USA 2008, vol. 105, s. 6730-6734.

Merchant Sabeeha S., Prochnik Simon E., Vallon Olivier, Harris Elizabeth H., Karpowicz Steven J., Witman George B., Terry Astrid, Salamov Asaf, Fritz-Laylin Lilian K., MARÉCHAL-DrouARD Laurence et al., „The Chlamydomonas Genome Reveals the Evolution of Key Animal and Plant Functions", Science 2007, vol. 318, s. 245-250.

MiereżKowski Konstantin, „Uber Natur und Ursprung der Chromatophoren im Pflanzenreiche”, Biologisches Centralblatt 1905, bd. 25, s. 593-604.

Miller David J. and Ball Eldon E., „Cryptic Complexity Captured: The Nematostella Genome Reveals Its Secrets", Trends in Genetics 2008, vol. 24, s. 1-4.

Mirkin Boris G., Fenner Trevor I., Galperin Michael Y., and Koonin Eugene V., „Algorithms for Computing Parsimonious Evolutionary Scenarios for Genome Evolution, the Last Universal Common Ancestor and Dominance of Horizontal Gene Transfer in the Evolution of Prokaryotes", BMC Evolutionary Biology 2003, vol. 3, no. 2.

Molina Nacho and van Nimwegen Erik, „The Evolution of Domain-Content in Bacterial Genomes", Biology Direct 2008, vol. 3, no. 51.

Mushegian Arcady R., „Gene Content of LUCA, the Last Universal Common Ancestor”, Frontiers in Bioscience 2008, vol. 13, s. 4657-4666.

Mushegian Arcady R. and Koonin Eugene V., „Gene Order Is Not Conserved in Bacterial Evolution”, Trends in Genetics 1996, vol. 12, s. 289-290.

Nelson Karen E., Clayton Rebecca A., Gill Steven R., Gwinn Michelle L., Dodson Robert J., Haft Daniel H., Hickey Erin K., Peterson Jeremy D., Nelson William C., Ketchum Karen A. et al., „Evidence for Lateral Gene Transfer Between Archaea and Bacteria from Genome Sequence of Thermotoga maritima", Nature 1999, vol. 399, s. 323-329.

Nierman William C., EIsen Jonathan A., Fleischmann Robert D., and Fraser Claire M., „Genome Data: What Do We Learn?", Current Opinion in Genetics and Development 2000 , vol. 10, s. 343-348.

Nikoh Naruo, Tanaka Kohjiro, Shibata Fukashi, Kondo Natsuko Ito, Hizume Masahiro, Shimada Masakazu, and FuKatsu Takema, „Wolbachia Genome Integrated in an Insect Chromosome: Evolution and Fate of Laterally Transferred Endosymbiont Genes", Genome Research 2008, vol. 18, s. 272-280.

Nosenko Tetyana and Bhattacharya Debashish, „Horizontal Gene Transfer in Chromalveolates”, BMC Evolutionary Biology 2007, vol. 7, no. 173. 
Novichkov Pavel S., Wolf Yuri I., DubchaK Inna, and Koonin Eugene V., „Trends in Prokaryotic Evolution Revealed by Comparison of Closely Related Bacterial and Archaeal Genomes", Journal of Bacteriology 2009, vol. 191, s. 65-73.

Ochman Howard and Moran Nancy A., „Genes Lost and Genes Found: Evolution of Bacterial Pathogenesis and Symbiosis”, Science 2001, vol. 292, s. 1096-1099.

Oнnо Susumu, Evolution by Gene Duplication, Springer-Verlag, Berlin - Heidelberg New York 1970.

Ohta Tomoko and Gillespie John H., „Development of Neutral and Nearly Neutral Theories", Theoretical Population Biology 1996, vol. 49, s. 128-142.

O'Malley Maureen A. and Boucher Yan, „Paradigm Change in Evolutionary Microbiology", Studies in History and Philosophy of Science Part C: Studies in History and Philosophy of Biological and Biomedical Sciences 2005, vol. 36, s. 183-208.

Orgel Leslie and Crick Francis H., „Selfish DNA: The Ultimate Parasite”, Nature 1980, vol. 284, s. 604-607.

PACE Norman R., ,A Molecular View of Microbial Diversity and the Biosphere”, Science 1997, vol. 276, s. 734-740.

PACE Norman R., „Time for a Change”, Nature 2006, vol. 441, s. 289.

Pagel Mark and Pomiankowski Andrew, (eds.), Evolutionary Genomics and Proteomics, Sinauer Associates, Inc., Sunderland, Massachusetts 2008.

PÁl Csaba, PAPp Balázs, and Hurst Laurence D., „Highly Expressed Genes in Yeast Evolve Slowly", Genetics 2001, vol. 158, s. 927-931.

PÁL Csaba, PAPP Balázs, and Lercher Martin J., „An Integrated View of Protein Evolution”, Nature Reviews Genetics 2006, vol. 7, s. 337-348.

Panopoulou Georgia, Hennig Steffen, Groth Detlef, Krause Antje, PoustKa Albert J., Herwig Ralf, Vingron Martin, and Lehrach Hans, „New Evidence for Genome-Wide Duplications at the Origin of Vertebrates Using an Amphioxus Gene Set and Completed Animal Genomes", Genome Research 2003, vol. 13, s. 1056-1066.

Park Jung Woo and Graveley Brenton R., „Complex Alternative Splicing”, Advances in Experimental Medicine and Biology 2007, vol. 623, s. 50-63.

Pereto Juli, Lopez-Garcia Purificacion, and Moreira David, „Ancestral Lipid Biosynthesis and Early Membrane Evolution", Trends in Biochemical Sciences 2004, vol. 29, s. 469477.

Perna Nicole T., Plunkett III Guy, Burland Valerie, Mau Bob, Glasner Jeremy D., Rose Debra J., Mayhew George F., Evans Peter S., Gregor Jason, KirkPatrick Heather A. et al., 
„Genome Sequence of Enterohaemorrhagic Escherichia coli O157:H7”, Nature 2001, vol. 409 , s. 529-533.

Petrusewicz Kazimierz (red.), Teoria ewolucji w wypisach, Wiedza Powszechna, Warszawa 1959.

Pheasant Michael and Mattick John S., „Raising the Estimate of Functional Human Sequences", Genome Research 2007, vol. 17, s. 1245-1253.

Piriyapongsa Jittima, Rutledge Mark T., Patel Sanil, Borodovsky Mark, and Jordan I. King, „Evaluating the Protein Coding Potential of Exonized Transposable Element Sequences", Biology Direct 2007, vol. 2, no. 31 .

Polavarapu Nalini, Mariño-Ramírez Leonardo, Landsman David, McDonald Jonh F., and JoRDAN I. King, „Evolutionary Rates and Patterns for Human Transcription Factor Binding Sites Derived from Repetitive DNA", BMC Genomics 2008, vol. 9, no. 226.

Poole Anthony M. and Penny David, „Eukaryote Evolution: Engulfed by Speculation”, $\mathrm{Na}$ ture 2007, vol. 447, s. 913.

Poole Anthony M. and Penny David, „Evaluating Hypotheses for the Origin of Eukaryotes", BioEssays 2007, vol. 29, s. 74-84.

Prangishvili David, Garrett Roger A., and Koonin Eugene V., „Evolutionary Genomics of Archaeal Viruses: Unique Viral Genomes in the Third Domain of Life", Virus Research 2006, vol. 117, s. 52-67.

Putnam Nicholas H., Srivastava Mansi, Hellsten Uffe, Dirks Bill, Chapman Jarrod, Salamov Asaf, Terry Astrid, Shapiro Harris, Lindquist Erika A., Kapitonov Vladimir V. et al., „Sea Anemone Genome Reveals Ancestral Eumetazoan Gene Repertoire and Genomic Organization", Science 2007, vol. 317, s. 86-94.

Ranea Juan A.G., Grant Alastair, Thornton Janet M., and Orengo Christine A., „Microeconomic Principles Explain an Optimal Genome Size in Bacteria", Trends in Genetics 2005, vol. 21, s. 21-25.

Rivera Maria C. and Lake James A., „The Ring of Life Provides Evidence for a Genome Fusion Origin of Eukaryotes", Nature 2004, vol. 431, s. 152-155.

Rogers Matthew B., Watkins Russell F., Harper James T., Durnford Dion G., Gray Michael W., and KeELing Patrick J., „A Complex and Punctate Distribution of Three Eukaryotic Genes Derived by Lateral Gene Transfer", BMC Evolutionary Biology 2007, vol. 7, no. 89.

Rogozin Igor B., Wolf Yuri I., Sorokin Alexander V., Mirkin Boris G., and Koonin Eugene V., ,Remarkable Interkingdom Conservation of Intron Positions and Massive, LineageSpecific Intron Loss and Gain in Eukaryotic Evolution", Current Biology 2003, vol. 13, s. $1512-1517$. 
Rokas Antonis and Carroll Sean B., „Bushes in the Tree of Life”, PLoS Biology 2006, vol. 4, e352.

Rose Michael R. and OAKLey Todd H., „The New Biology: Beyond the Modern Synthesis”, Biology Direct 2007, vol. 2, no. 30.

Roy Scott W., „Intron-Rich Ancestors”, Trends in Genetics 2006, vol. 22, s. 468-471.

Roy Scott W. and Gilbert Walter, „The Evolution of Spliceosomal Introns: Patterns, Puzzles and Progress", Nature Reviews Genetics 2006, vol. 7, s. 211-221.

SAGAN Lynn, „On the Origin of Mitosing Cells”, Journal of Theoretical Biology 1967, vol. 14, s. 255-274.

Sawyer Stanley A., Parsch John, Zhang Zhi, and Hartl Daniel L., „Prevalence of Positive Selection Among Nearly Neutral Amino Acid Replacements in Drosophila", Proceedings of the National Academy of Sciences USA 2007, vol. 104, s. 6504-6510.

Scannell Devin R., Butler Geraldine, and Wolfe Kenneth H., „Yeast Genome Evolution — The Origin of the Species", Yeast 2007, vol. 24, s. 929-942.

Scannell Devin R. and Wolfe Kenneth H., „A Burst of Protein Sequence Evolution and a Prolonged Period of Asymmetric Evolution Follow Gene Duplication in Yeast", Genome Research 2008, vol. 18, s. 137-147.

Schneiker Susanne, Perlova Olena, Kaiser Olaf, Gerth Klaus, Alici Aysel, Altmeyer Matthias O., Bartels Daniela, Berel Thomas, Beyer Stefan, Bode Edna et al., „Complete Genome Sequence of the Myxobacterium Sorangium cellulosum”, Nature Biotechnolology 2007, vol. 25, s. 1281-1289.

SÉmon Marie and Wolfe Kenneth H., „Consequences of Genome Duplication”, Current Opinion in Genetics and Development 2007, vol. 17, s. 505-512.

She Qunxin, Singh Rama K., Confalonieri Fabrice, Zivanovic Yvan, Allard Ghislaine, Awayez Mariana J., Chan-Weiher Christina C.-Y., Clausen Ib Groth, Curtis Bruce A., De Moors Anick et al., „The Complete Genome of the Crenarchaeon Sulfolobus solfataricus P2", Proceedings of the National Academy of Sciences USA 2001, vol. 98, s. 7835-7840.

Simpson George Gaylord, Tempo and Mode in Evolution, Columbia University Press, New York 1944.

Snel Berend, Bork Peer, and Huynen Martjin A., „Genomes in Flux: The Evolution of Archaeal and Proteobacterial Gene Content”, Genome Research 2002, vol. 12, s. 17-25.

Soltis Douglas E., Bell Charles D., Kim Sangtae, and Soltis Pamela S., „Origin and Early Evolution of Angiosperms”, Annals of the New York Academy of Sciences 2008, vol. 1133, s. 3-25. 
Sorex Rotem, Shamir Ron, and Ast Gil, „How Prevalent Is Functional Alternative Splicing in the Human Genome?", Trends in Genetics 2004, vol. 20, s. 68-71.

Srivastava Mansi, Begovic Emina, Chapman Jarrod, Putnam Nicholas H., Hellsten Uffe, Kawashima Takeshi, Kuo Alan, Mitros Therese, Salamov Asaf, Carpenter Meredith L. et al., „The Trichoplax Genome and the Nature of Placozoans”, Nature 2008, vol. 454, s. $955-960$.

Swain Amanda and Coffin John M., „Mechanism of Transduction by Retroviruses”, Science 1992, vol. 255, s. 841-845.

Syvanen Michael, „Molecular Clocks and Evolutionary Relationships: Possible Distortions Due to Horizontal Gene Flow", Journal of Molecular Evolution 1987, vol. 26, s. 16-23.

Syvanen Michael and Kado Clarence I. (eds.), Horizontal Gene Transfer, Academic Press, San Diego 2002.

TАKAнAтA Naoyuki, „On the Overdispersed Molecular Clock”, Genetics 1987, vol. 116, s. $169-179$.

TAx Sol (ed.), The Evolution of Life: Evolution After Darwin, vol. 1, University of Chicago Press, Chicago 1959.

Tax Sol and Callender Charles (eds.), Evolution After Darwin: The University of Chicago Centennial, University of Chicago Press, Chicago 1960.

Tномаs Charlie A., Jr., „The Genetic Organization of Chromosomes”, Annual Review of Genetics 1971, vol. 5, s. 237-256.

TilLIER Elisabeth R. and Coluins Richard A., „Genome Rearrangement by Replication-Directed Translocation", Nature Genetics 2000, vol. 26, s. 195-197.

Tobiason Deborah M. and Seifert H. Steven, „The Obligate Human Pathogen, Neisseria gonorrhoeae, Is Polyploid”, PLoS Biology 2006, vol. 4, e185.

Tringe Susannah G., von Mering Christian, Kobayashi Arthur, Salamov Asaf A., Chen Kevin, Chang Hwai W., Podar Mircea, Short Jay M., Mathur Eric J., Detter J. Chris et al., „Comparative Metagenomics of Microbial Communities”, Science 2005, vol. 308, s. 554557.

Tuskan Gerald A., Difazio Stephen, Jansson Stefan, Bohlmann J., Grigoriev Igor, Hellsten Uffe, Putnam Nicholas, Ralph S., Rombauts Stephane, Salamov Asaf et al., „The Genome of Black Cottonwood, Populus trichocarpa (Torr. \& Gray)", Science 2006, vol. 313, s. $1596-1604$

Ulrich Luke E., Koonin Eugene V., and Zhulin Igor B., „One-Component Systems Dominate Signal Transduction in Prokaryotes", Trends in Microbiology 2005, vol. 13, s. 52-56. 
van Nimwegen Erik, „Scaling Laws in the Functional Content of Genomes”, Trends in Genetics 2003, vol. 19, s. 479-484.

van Nimwegen Erik, „Scaling Laws in the Functional Content of Genomes”, w: Koonin, Wolf, and Karev (eds.), Power Laws..., s. 236-253.

WAGNER Andreas, „Robustness, Evolvability, and Neutrality”, FEBS Letters 2005, vol. 579, s. $1772-1778$

Wagner Gunte P., Amemiya Chris, and Ruddle Frank, „Hox Cluster Duplications and the Opportunity for Evolutionary Novelties", Proceedings of the National Academy of Sciences USA 2003, vol. 100, s. 14603-14606.

Wallace Alfred R., „O dążności odmian do nieograniczonego odbiegania od typu pierwotnego", przeł. Kazimierz Szarski, w: Petrusewicz (red.), Teoria ewolucji w wypisach..., s. $81-91$.

Wallace Alfred R., „On the Tendency of Species to Form Varieties; And on the Perpetuation of Varieties and Species by Natural Means of Selection. III. On the Tendency of Varieties to Depart Indefinitely from the Original Type", Journal of the Proceedings of the Linnean Society of London 1858, vol. 3, s. 53-62.

Wellner Alon, Lurie Mor N., and Gophna Uri, „Complexity, Connectivity, and Duplicability as Barriers to Lateral Gene Transfer", Genome Biology 2007, vol. 8, s. R156.

Wilson Allan C., Carlson Steven S., and White Thomas J., „Biochemical Evolution”, Annual Review of Biochemistry 1977, vol. 46, s. 573-639.

Woese Carl R., „Bacterial Evolution”, Microbiological Reviews 1987, vol. 51, s. 221-271.

Woese Carl R., „There Must Be a Prokaryote Somewhere: Microbiology’s Search for Itself", Microbiological Reviews 1994, vol. 58, s. 1-9.

Woese Carl R., „The Universal Ancestor”, Proceedings of the National Academy of Sciences USA 1998, vol. 95, s. 6854-6859.

Woese Carl R. and Fox George E., „Phylogenetic Structure of the Prokaryotic Domain: The Primary Kingdoms", Proceedings of the National Academy of Sciences USA 1977, vol. 74, s. $5088-5090$.

Woese Carl R., Kandler Otto, and Wheelis Mark L., „Towards a Natural System of Organisms: Proposal for the Domains Archaea, Bacteria, and Eucarya", Proceedings of the National Academy of Sciences USA 1990, vol. 87, s. 4576-4579.

Woese Carl R., Magrum Linda J., and Fox George E., „Archaebacteria”, Journal of Molecular Evolution 1978, vol. 11, s. 245-251. 
Wolf Maxim Y., Wolf Yuri I., and Koonin Eugene V., „Comparable Contributions of Structural-Functional Constraints and Expression Level to the Rate of Protein Sequence Evolution", Biology Direct 2008, vol. 3, no. 40.

Wolf Yuri I., Carmel Liran, and Koonin Eugene V., „Unifying Measures of Gene Function and Evolution", Proceedings of the Royal Society of London B: Biological Sciences 2006, vol. 273, s. 1507-1515.

Wolf Yuri I., Rogozin Igor B., Grishin Nick V., and Koonin Eugene V., „Genome Trees and the Tree of Life", Trends in Genetics 2002, vol. 18, s. 472-479.

Wolfe Kenneth H. and SHIELDs Denis C., „Molecular Evidence for an Ancient Duplication of the Entire Yeast Genome", Nature 1997, vol. 387, s. 708-713.

Wright Sewall, Evolution: Selected Papers, University of Chicago Press, Chicago 1986.

XIong Yue and EıckBush Thomas H., „Origin and Evolution of Retroelements Based Upon Their Reverse Transcriptase Sequences”, EMBO Journal 1990, vol. 9, s. 3353-3362.

Yampolsky Lev Y., Kondrashov Fyodor A., and KondRashov Alexey S., „Distribution of the Strength of Selection Against Amino Acid Replacements in Human Proteins", Human Molecular Genetics 2005, vol. 14, s. 3191-3201.

Yooseph Shibu, Sutton Granger, Rusch Douglas B., Halpern Aaron L., Williamson Shannon J., Remington Karin, Eisen Jonathan A., Heidelberg Karla B., Manning Gerard, Li Weizhong et al., ,The Sorcerer II Global Ocean Sampling Expedition: Expanding the Universe of Protein Families", PLoS Biology 2007, vol. 5, e16.

Yutin Natalya, Makarova Kira S., Mekhedov Sergey L., Wolf Yuri I., and Koonin Eugene V., „The Deep Archaeal Roots of Eukaryotes”, Molecular Biology and Evolution 2008, vol. 25 , s. 1619-1630.

Zhang Jianzhi, „Frequent False Detection of Positive Selection by the Likelihood Method with Branch-Site Models", Molecular Biology and Evolution 2004, vol. 21, s. 1332-1339.

ZuckerkandL Emile, „Why So Many Noncoding Nucleotides?: The Eukaryote Genome as an Epigenetic Machine", Genetica 2002, vol. 115, s. 105-129.

Zuckerkandl Emile and Pauling Linus, „Evolutionary Divergence and Convergence in Proteins", w: Bryson and Vogel (eds.), Evolving Gene and Proteins..., s. 97-166.

Zuckerkandl Emile and Pauling Linus, ,Molecular Disease, Evolution and Genic HeteroGeneity", w: Kasha and Pullman (eds.), Horizons in Biochemistry..., s. 189-225. 


\title{
Ewolucjonizm darwinowski w świetle genomiki
}

\begin{abstract}
Streszczenie
Genomika porównawcza i biologia systemowa oferują niespotykane możliwości testowania głównych zasad biologii ewolucyjnej sformułowanych przez Darwina w $\mathbf{O}$ powstawaniu gatunków w 1859 roku i rozszerzonych sto lat później w ramach Nowoczesnej Syntezy. Badania w dziedzinie genomiki ewolucyjnej pokazują, że dobór naturalny stanowi tylko jedną z sił kształtujących ewolucję genomu i wcale nie występującą najczęściej, natomiast procesy nieadaptacyjne mają znacznie większe znaczenie niż wcześniej przypuszczano. Duży wkład horyzontalnego transferu genów i różnych samolubnych elementów genetycznych w ewolucję genomu podważa koncepcję drzewa życia. Adekwatny opis ewolucji wymaga bardziej złożonej koncepcji sieci lub „lasu” życia. Nie istnieje spójny trend ewolucji w kierunku większej złożoności genomowej, a kiedy złożoność wzrasta, wydaje się, że jest to raczej nieadaptacyjna konsekwencja ewolucji drogą słabego doboru oczyszczającego niż adaptacji. Odkryto rozmaite powszechniki ewolucji genomu, w tym niezmiennicze rozkłady tempa ewolucji pośród genów ortologowych z różnych genomów oraz rozmiarów rodzin genów paralogowych. Dostrzeżono też negatywną korelację między poziomem ekspresji genów a tempem ewolucji sekwencji. Niektóre z tych powszechników uzyskują wyjaśnienie dzięki zastosowaniu prostych, nieadaptacjonistycznych modeli ewolucji, co sugeruje, że w dość nieodległej przyszłości powstać może nowa synteza biologii ewolucyjnej.
\end{abstract}

Slowa kluczowe: darwinizm, Nowoczesna Synteza, genomika ewolucyjna, biologia systemowa, Postnowoczesna Synteza biologii ewolucyjnej, dobór oczyszczający, neutralne procesy ewolucyjne, nieadaptacjonistyczna teoria ewolucji.

\section{Darwinian Evolution in the Light of Genomics}

\section{Summary}

Comparative genomics and systems biology offer unprecedented opportunities for testing central tenets of evolutionary biology formulated by Darwin in the Origin of Species in 1859 and expanded in the Modern Synthesis 100 years later. Evolutionary-genomic studies show that natural selection is only one of the forces that shape genome evolution and is not quantitatively dominant, whereas non-adaptive processes are much more prominent than previously suspected. Major contributions of horizontal gene transfer and diverse selfish genetic elements to genome evolution undermine the Tree of Life concept. An adequate depiction of evolution requires the more complex concept of a network or "forest" of life. There is no consistent tendency of evolution towards increased genomic complexity, and when complexity increases, this appears to be a non-adaptive consequence of evolution under weak purifying selection rather than an adaptation. Several universals of genome evolution were discovered including the invariant distributions of evolutionary rates among orthologous genes from diverse genomes and of paralogous gene family sizes, and the nega- 
tive correlation between gene expression level and sequence evolution rate. Simple, nonadaptive models of evolution explain some of these universals, suggesting that a new synthesis of evolutionary biology might become feasible in a not so remote future.

Keywords: Darwinism, Modern Synthesis, evolutionary genomics, systems biology, Postmodern Synthesis of evolutionary biology, purifying selection, neutral evolutionary processes, non-adaptationist theory of evolution. 